UNIVERSIDADE DE SÃO PAULO

FACULDADE DE ODONTOLOGIA

\title{
RESPONSABILIDADE CIVIL DO CIRURGIÃO DENTISTA: O PÓS-TRATAMENTO ORTODÔNTICO
}

\section{FERNANDO FERNANDES}

Dissertação apresentada à Faculdade de Odontologia da Universidade de São Paulo, para concorrer ao Título de Mestre, pelo curso de Pós-Graduação em Odontologia. Área de concentração em Deontologia e Odontologia Legal.

SÃO PAULO

2000 
Data da Defesa: 14,12100

Banca Examinadora
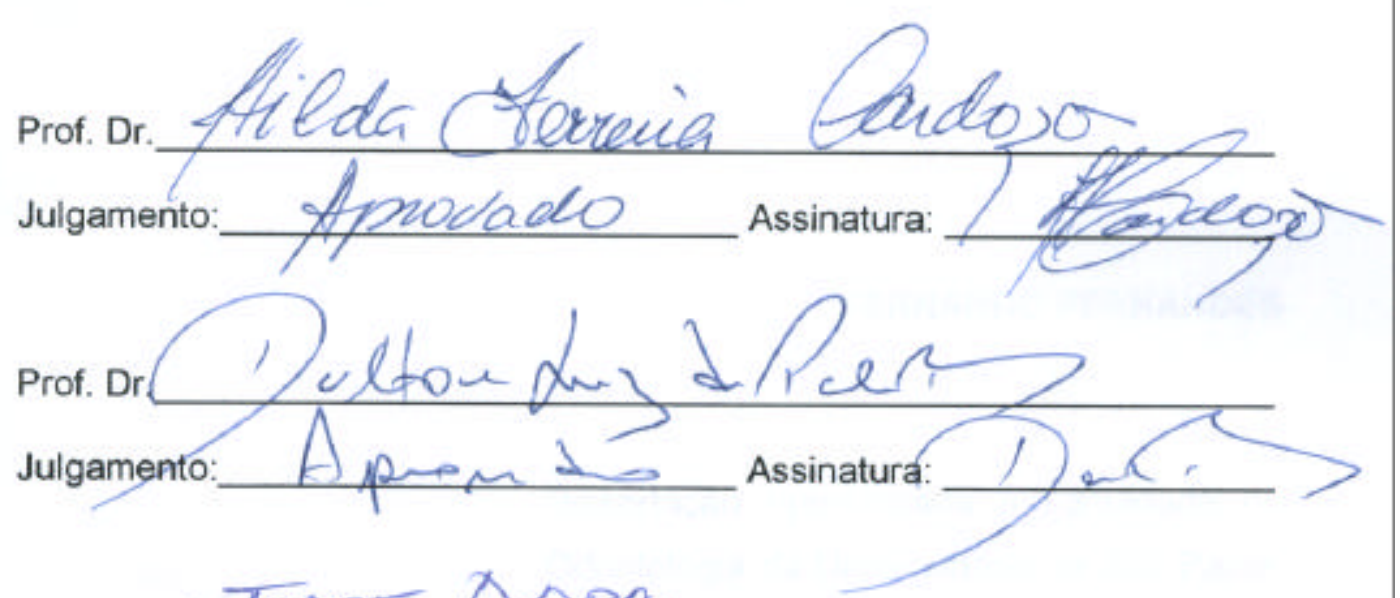

Prof. Dr. Toxat Alepo

Julgamento: $\triangle$ PeOU A De

Assinatura:

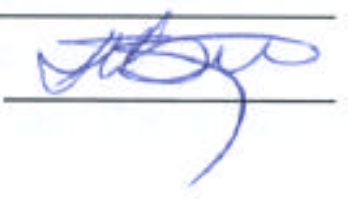




\section{Catalogação-na-Publicação}

Serviço de Documentaçã̃o Odontológica

Faculdade de Odontologia da Universidade de São Paulo

Fernandes, Fernando

Responsabilidade civil do cirurgião dentista : o pós-tratamento ortodôntico / Fernando Fernandes ; orientador Hilda Ferreira Cardozo. -- São Paulo, 2000.

150f. ; tab ; graf.

Dissertação (Mestrado - Curso de Pós-Graduação em Odontologia. Área de Concentração em Deontologia e Odontologia Legal) -- Faculdade de Odontologia da Universidade de São Paulo.

1. Cirurgião-Dentista - Tratamento pós-ortodôntico - Responsabilidade civil Responsabilidade civil - Tratamento pós-ortodôntico 3. Odontologia legal 


\section{DEDICATÓRIA}

Se...

Se não fosse você...

Se não fosse por você...

Se não fosse com você...

Jenny

Tardaria ainda mais

Tardaria ainda mais esta obra

Obra esta iniciada já há alguns anos

Há alguns anos...

Porém dormente,

Dormente no fundo d'alma.

E lá...

Lá no mais fundo e precioso d'alma, você me tocou!

Tocou tal qual a névoa branca

Eh! Despertou. Despertou algo inexplicável!

Forte;

Seguro;

Marcante;

Significante.

Assim, juntos caminhamos...

Caminharemos sempre juntos.

Seu amor fortalece essa longa trilha.

Trilha essa..., da vida!

Também dedico este trabalho aos meus filhos Eliana, Fernando e Mário Rene. 


\section{AGRADECIMENTOS}

Agradeço aos meus pais, Humberto Rene Fernandes e Therezinha Schafranski Fernandes, pelo que hoje sou e como sou.

Lembro, in memoriam, meu irmão Mauro Cézar Fernandes.

À Profa. Dra. Hilda Ferreira Cardozo, minha orientadora, pelo respeito, amizade, compreensão e paciência frente as minhas dificuldades, tenho muito a agradecer. Sua orientação segura, precisa e objetiva, em todas as fases do meu mestrado, permitiu-me a realização deste trabalho e também abriu-me novos horizontes.

Ao Prof. Dr. Moacyr da Silva, Coordenador do Curso de PósGraduação em Deontologia e Odontologia Legal da Faculdade de Odontologia da Universidade de São Paulo (FOUSP), pela convivência pessoal e a atenção que me foi concedida.

Ao Prof. Dr. Dalton Luiz de Paula Ramos, D.D. Chefe do Departamento de Odontologia Social da referida Faculdade, pelo exemplo de dedicação e pela amizade.

À Profa. Dra. Ida T. P. Calvielli, por estar sempre preocupada em repassar seus conhecimentos a todos nós mestrandos, meu muito obrigado. 
Aos Professores do Curso de Pós-Graduação em Deontologia e Odontologia Legal da FOUSP, pelos ensinamentos transmitidos.

Aos amigos da quarta turma do Curso de Pós-Graduação (Mestrado) em Deontologia e Odontologia Legal da Faculdade de Odontologia da Universidade de São Paulo, o meu carinho.

À Universidade Estadual de Ponta Grossa (UEPG) que, acreditando em minhas qualidades, possibilitou-me a participação no curso de Pós-Graduação em Deontologia e Odontologia Legal da FOUSP.

Aos Professores Zeno Baroncini Filho, Elias Zahi Fadel, Protásio Vargas Neto e Dr. João Carlos Gomes, pela confiança depositada ao indicarem-me para a realização do curso.

Aos demais Professores do Departamento de Odontologia da Universidade Estadual de Ponta Grossa, meus sinceros agradecimentos.

À Profa. Maria Beatriz Fernandes Ferreira, pela revisão ortográfica e gramatical do texto.

Ao amigo Rogério Ranthum, pelo seu auxílio e conhecimento na área de informática.

À Bibliotecária Luzia Marilda Z. M. e Moraes, do Serviço de Documentação Odontológica da FOUSP, pelo auxílio às normas para a apresentação de dissertações.

À Bibliotecária Maria Etelvina Madalozzo Ramos, da Universidade Estadual de Ponta Grossa, pelo auxílio na normatização bibliográfica. 
Às Secretarias do Departamento de Odontologia Social da FOUSP e do Departamento de Odontologia da UEPG, pela presteza com que sempre me atenderam.

À Coordenação de Aperfeiçoamento de Pessoal de Nível Superior (CAPES), pela bolsa de estudo concedida no Programa Institucional de Capacitação Docente e Técnica (PICDT).

Finalmente, a todos que, direta ou indiretamente contribuíram para a minha formação acadêmica e realização deste trabalho, meu muito obrigado! 
A pessoa humana total, na condição de cidadã, é uma parte desta sociedade, à qual todavia ela transcende em razão dos valores absolutos a que se liga $e$ em razão do que nela visa um destino superior ao tempo.

Jacques Maritain 


\section{SUMÁRIO}

\section{RESUMO}

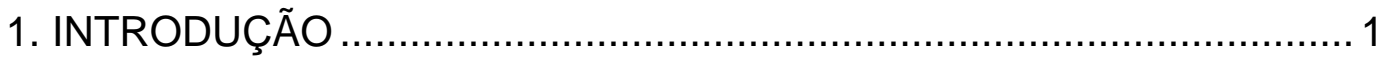

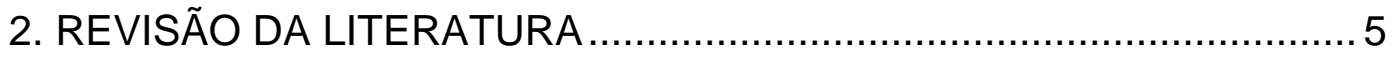

2.1 Responsabilidade civil do cirurgião dentista......................................

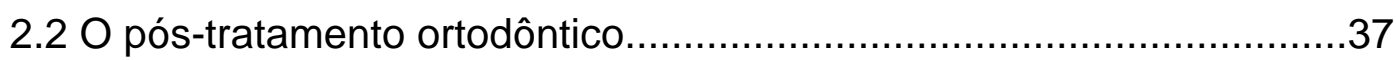

2.3 O profissional liberal no código de defesa do consumidor..................56

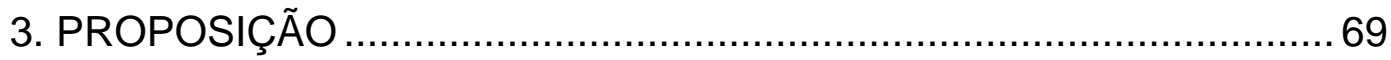

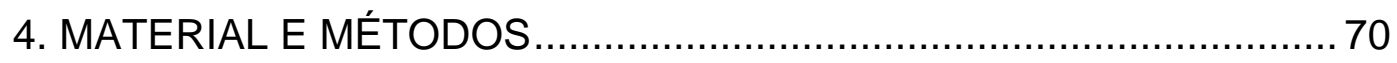

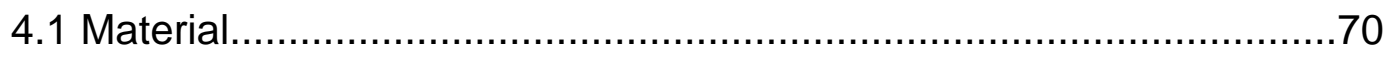

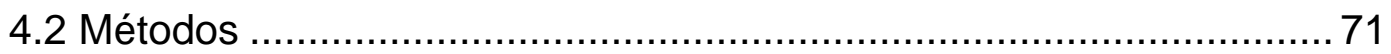

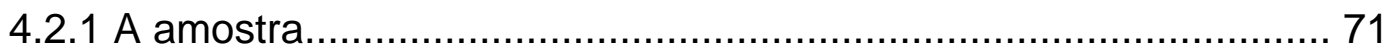

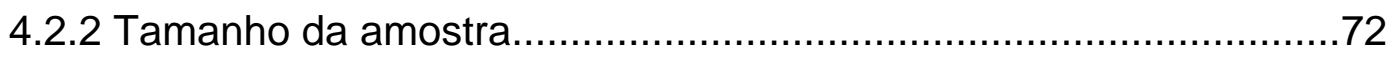

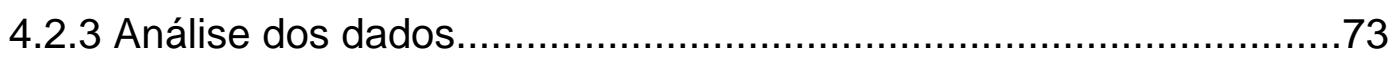

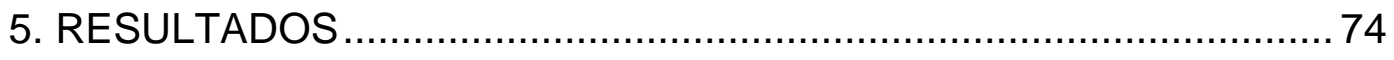

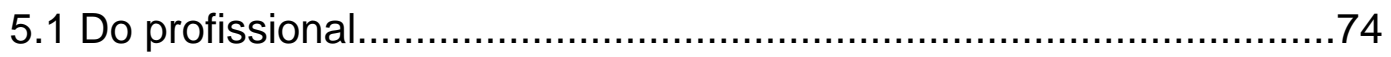

5.2 Da documentação profissional....................................................

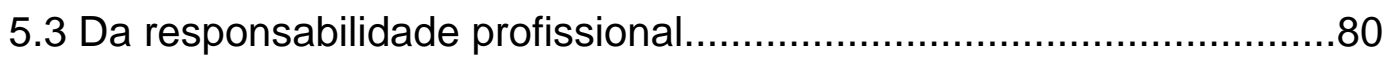

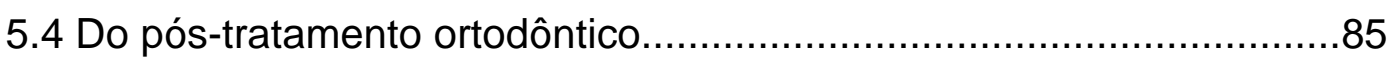




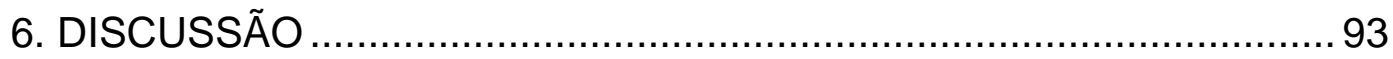

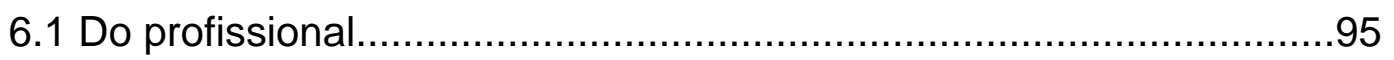

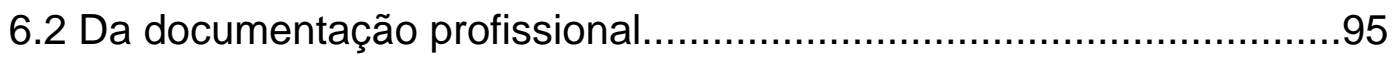

6.3 Da responsabilidade profissional................................................101

6.4 Do pós-tratamento ortodôntico.....................................................112

6.4.1 Adotar como rotina aparelhos de contenção................................113

6.4.2 Período recomendado de uso dos aparelhos de contenção..........113

6.4.3 Tempo recomendado de uso dos aparelhos de contenção...........114

6.4.4 Tempo que o profissional mantém o retentor inferior colado.........117

6.4.5 Conduta adotada pelo profissional nos casos de recidiva durante o

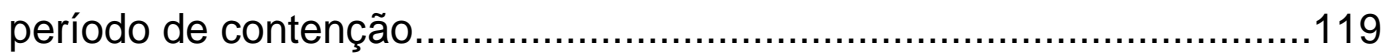

6.4.6 Freqüência com que o profissional supervisiona o paciente no período pós-contenção

6.4.7 Conduta adotada pelo profissional nos casos de recidiva após o período de contenção 124

6.4.8 Conduta adotada pelo profissional perante o paciente insatisfeito com os resultados do tratamento ortodôntico. .127

6.4.9 Profissional envolvido numa ação de responsabilidade civil.........130

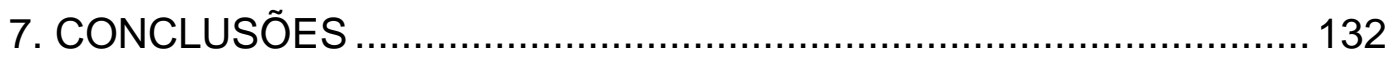

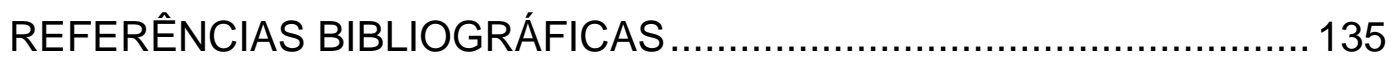

SUMMARY

APÊNDICES 


\section{LISTA DE FIGURAS}

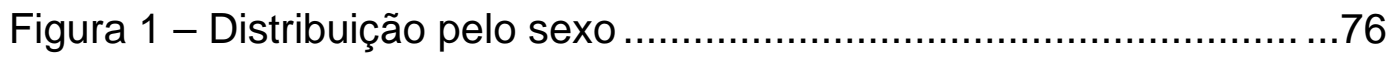

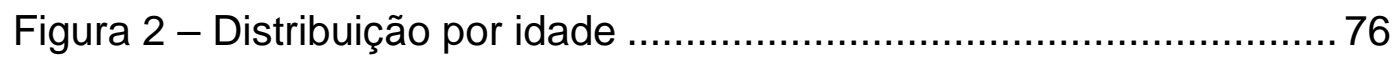

Figura 3 - Formação acadêmica....................................................... 77

Figura 4 - Solicitação da documentação inicial.......................................78

Figura 5-Solicitação da documentação ao término do tratamento

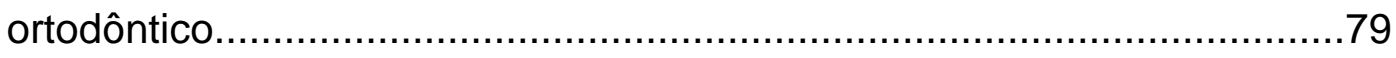

Figura 6 - Período de arquivamento da documentação.............................79

Figura 7 - Consciência plena da limitação do tempo para reclames à Justiça em relação ao tratamento odontológico. .80

Figura 8 - Conhecimento do profissional a respeito do Art.177 do CCB..81

Figura 9-Conhecimento do profissional no que diz respeito ao termo sublinhado: as provas que porventura o CD apresente à justiça são préconstituídas

Figura 10 - Adotar algum modelo ou forma de contrato............................82

Figura 11 - Fazer ressalvas no corpo do contrato.................................82

Figura 12 - Ciência da validade das ressalvas no contrato.......................83

Figura 13 - Natureza jurídica da responsabilidade profissional................83 
Figura 14-Procedimento adotado pelo cirurgião dentista quando o paciente solicita a retirada de documentos............................................84 Figura 15 - Período recomendado de uso dos aparelhos de contenção..85 Figura 16 - Condutas adotadas nos casos de recidiva durante o período de contenção .88

Figura 17 - Condutas adotadas nos casos de recidiva após o período de contenção. .89

Figura 18 - Freqüência de supervisão no período pós-contenção............90

Figura 19 - Conduta adotada perante a insatisfação do paciente.............91

Figura 20 - CD envolvido numa ação de responsabilidade civil...............92 


\section{LISTA DE TABELAS}

TABELA 5.1 - Número de cartas-resposta recebidas por município...........75

TABELA 5.2 - Tempo recomendado de uso dos aparelhos de contenção..86

TABELA 5.3 - Distribuição das respostas referentes ao tempo que o profissional mantém o retentor inferior colado......................................87 


\section{LISTA DE ABREVIATURAS E SIGLAS}

$\begin{array}{ll}\text { ABOR } & \text { Associação Brasileira de Ortodontia } \\ \text { aC } & \text { Antes de Cristo } \\ \text { CCB } & \text { Código Civil Brasileiro } \\ \text { CD } & \text { Cirurgião dentista } \\ \text { CDC } & \text { Código de Defesa do Consumidor } \\ \text { CEO } & \text { Código de Ética Odontológica } \\ \text { CF } & \text { Constituição Federal } \\ \text { CFM } & \text { Conselho Federal de Medicina } \\ \text { CFO } & \text { Conselho Federal de Odontologia } \\ \text { CPB } & \text { Código Penal Brasileiro } \\ \text { CREMEMG } & \text { Conselho Regional de Medicina do Estado de Minas Gerais } \\ \text { CRO } & \text { Conselho Regional de Odontologia } \\ \text { SBO } & \text { Sociedade Brasileira de Ortodontia }\end{array}$




\section{LISTA DE SÍMBOLOS}

(sempre colocar em ordem alfabética) 


\section{RESUMO}

\section{RESPONSABILIDADE CIVIL DO CIRURGIÃO DENTISTA: O PÓS-TRATAMENTO ORTODÔNTICO}

O objetivo deste trabalho foi investigar quais os procedimentos clínicos e as dificuldades do ortodontista no pós-tratamento ortodôntico (contenção e pós-contenção), verificando se as condutas adotadas satisfazem possíveis reclames de pacientes que já terminaram o tratamento corretivo, com base nas determinações do Código Civil e do Código de Defesa do Consumidor quanto ao relacionamento profissional/paciente. A literatura ortodôntica é controversa no que diz respeito a técnicas, tempo, estabilidade e dificuldades inerentes ao tratamento. Um questionário foi enviado pelo correio a todos os especialistas inscritos no CRO/PR; 95 deles enviaram respostas. A análise percentual das respostas obtidas demonstrou que $73,6 \%$ dos profissionais não têm consciência plena do tempo para reclamos à Justiça em relação ao tratamento odontológico. Não conhecem o Art.177 do CCB (83,1\%). Adotam contrato (67\%), fazem ressalvas (48\%), porém não estão cientes da validade das mesmas (59\%). A maioria (60\%) considera a Responsabilidade Civil do ortodontista como de resultado. Nos casos de recidiva pós-contenção, 70\% propõem retratamento ortodôntico. 
Perante a insatisfação do paciente com o resultado do tratamento ortodôntico, 55\% dos profissionais responderam que procurariam, de qualquer forma, evitar que o mesmo impetrasse ação de ordem cível. 0 desconhecimento da Lei e a existência de controvérsias no pós-tratamento ortodôntico, podem estar levando o ortodontista a responder civilmente pelas movimentações dentárias e alterações neuromusculares que ocorrerem nessa fase. 


\section{INTRODUÇÃO}

A responsabilidade no campo civil é concretizada em cumprimento da obrigação de fazer ou de não fazer e no pagamento de condenação em dinheiro. Em geral, essa responsabilidade manifesta-se na aplicação desse dinheiro na atividade de prevenção ou de reparação do prejuízo (Oliveira, 1999).

A responsabilidade civil, vista genericamente, está na ocorrência de um nexo causal entre duas circunstâncias, no mínimo: a) a conduta de alguém, que se afigurará como ofensiva; b) o aparecimento de um dano resultante da conduta. Nessas circunstâncias, que se vinculam como causa e efeito, está o substrato, o cerne da responsabilidade civil, embora em alguns casos se exija um elemento subjetivo do agente para tipificar civilmente a conduta. Esta pode ser omissiva ou comissiva, sendo que a omissão deve se qualificar de relevância jurídica (Nascimento, 1991).

O paciente é um ser humano carente de ajuda, que deseja obter a opinião de um profissional capacitado, querendo ser bem tratado, ouvido e informado sobre sua real situação e o tratamento a ser adotado. A capacidade de controle e avaliação do paciente sobre assuntos técnicos 
médicos e odontológicos é muito pequena, o que aumenta a responsabilidade dos profissionais (Quest Consultoria e Treinamento, 1998).

Pacientes ortodônticos de uma época menos evoluída da odontologia, anterior aos anos setenta, pouco ou quase nada sabiam sobre seus direitos de consumidor brasileiro. Medicina e Odontologia ainda eram vistas com respeito tal que por si só desencorajava a propositura de ação pessoal para reparação de eventual dano decorrente do tratamento. Com o advento do Código de Defesa do Consumidor, as relações de consumo foram significativamente alteradas no que diz respeito à responsabilidade civil do fornecedor.

Segundo Prux, o Código de Defesa do Consumidor, basicamente, prevê três tipos de situações das quais se pode inferir responsabilidade civil por parte do fornecedor. São elas: "o fato do produto ou do serviço; o vício do produto ou do serviço; as condutas e práticas abusivas". Contextualiza o autor, “... fornecedor é o profissional liberal que adentra o mercado para prestar serviços a consumidor, sempre o fazendo em caráter pessoal e profissional' (Prux, 1998, p.114).

Quando o profissional Cirurgião Dentista recebe um paciente para tratamento, estabelecem-se relações que atualmente estão mais voltadas para os compromissos assumidos com convênios e/ou credenciamentos do que a própria indicação do nome e reputação do profissional que, antes, constituía a base da própria confiabilidade no profissional (Calvielli, 1997).

Diante disso, qualquer clínico abordará necessariamente, dentro da sua conduta profissional, três fases distintas: 
- antes do tratamento;

- durante o tratamento;

- após o tratamento.

$\mathrm{Na}$ ortodontia, antes do tratamento, a consulta inicial será o primeiro contato no qual se estabelecerá a relação paciente/profissional. Essa consulta inicial deverá ser bem procedida, pois através dela o profissional estará colhendo dados e assim iniciando uma documentação odontológica. A composição do prontuário odontológico (documentação) será o instrumento a nortear passos futuros.

Destarte, a apresentação do plano de tratamento ao paciente, bem como suas alternativas, passando pela sua execução e respectiva conclusão, a relação paciente/profissional deverá ser interativa. Durante o desenvolvimento do tratamento ortodôntico serão distribuídas ações de competência exclusiva do profissional e aquelas atribuídas ao paciente.

Após o tratamento, cumprido o acordado na forma escrita, verbal ou tácita, inicia-se uma nova fase que, para Riedel (1960), significa manter os dentes em posição funcional e estética ideais após o tratamento ortodôntico específico.

O dever do profissional em zelar pela saúde oral do seu paciente encontra-se respaldado na Deontologia Odontológica.

A estabilidade tem sido o objetivo primordial do tratamento ortodôntico. O planejamento de um caso clínico remete diretamente à fase pós-correção, em que a estabilidade estará relacionada a uma oclusão adequada, preservando o equilíbrio neuromuscular e estabelecendo o 
relacionamento das bases apicais. Assim, a própria fase de contenção estará dependente do que é obtido durante o tratamento ortodôntico.

Durante o $97^{\circ}$ Seminário Internacional de Ortodontia da Sociedade Brasileira de Ortodontia (SBO), realizado em 1997, na cidade do Rio de Janeiro, Horn enfatizou em seu curso (A Ortodontia Hoje na Europa) que o ortodontista, ao planejar um caso clínico, deverá antecipar o envelhecimento natural da face do paciente e ressaltou que, assim procedendo, o ortodontista trabalha para a estabilidade. Ademais, salientou ser inadequado o uso da contenção para o resto da vida do paciente.

Há um consenso de que não cabe ao ortodontista apenas o tratamento da maloclusão do paciente, mas também manter os resultados obtidos com o tratamento ortodôntico.

Cremos que a temática é complexa e muito relevante. Não tem uma solução única e simplista. Necessita evoluir.

Considerando a importância, controvérsias e dificuldades inerentes do pós-tratamento ortodôntico, esta dissertação volta-se para o estudo da Responsabilidade Civil do Cirurgião Dentista e suas condutas no PósTratamento Ortodôntico. 


\section{REVISÃO DA LITERATURA}

A presente pesquisa está direcionada à responsabilidade civil do cirurgião dentista, especificamente no que se refere pós-tratamento ortodôntico. Por esse motivo, para termos uma base histórica sobre essa linha de pesquisa, foi necessário enfocar estudos que estão direta ou indiretamente relacionados com a Deontologia Odontológica e Ortodontia.

Destarte, para melhor compreensão, dividimos este capítulo em: 2.1

Responsabilidade Civil do cirurgião dentista; 2.2 O pós-tratamento ortodôntico; e 2.3 O profissional liberal no Código de Defesa do Consumidor.

\subsection{Responsabilidade Civil do cirurgião dentista}

Machado (2000) historiou em sua obra, com muita propriedade, a utilização do termo responsável:

“... O termo responsabilidade está ausente no Direito Romano.

Ele não aparece nas línguas européias senão no fim do século XVIII, afirma o professor Michel Villey da Universidade de Direito, Economia e Ciências Sociais de Paris. Contudo, encontra-se o termo 
responsável depois do século XIII, através dos termos 'responsum', derivado de 'respondere'.

(...) 'Respondere' leva a 'sponsio', instituição que tinha um lugar central no Direito Romano arcaico, e a 'spondere'. O 'sponsor' é um devedor: o homem que no diálogo da estipulação, por uma resposta afirmativa à questão do estipulante, futuro credor, engajava-se em alguma prestação. O 'responsor' era especialmente a caução; em uma segunda troca de palavras, ele se obrigava a responder sobre a dívida principal de outrem.

Quanto ao termo responsável ('responsabilis') ele não aparece senão na idade média, consoante a lição do professor Villey. O termo aplicase à questão ou à petição que é suscetível ou não de uma resposta. Na origem de responder ou ser responsável não há, de forma alguma, a culpa. Prossegue o jurista da Universidade de Paris: 0 fundamento do regime romano de reparação de danos não é a culpa, mas a defesa de uma justa repartição entre os bens partilisados entre as famílias, isto é, de um justo equilíbrio. 'Suum cui que tribuere, aequabilitas'. Quando intervém uma ruptura deste equilíbrio, um prejuízo contrário ao direito e à justiça ('damnum injuria datum'), entra em jogo a justiça chamada corretiva, cuja função será reduzir o desequilíbrio. A noção de culpa era utilizada especificamente para os crimes. Por fim, menciono a adequada análise do professor francês: a doutrina do século XIX elabora a teoria da Responsabilidade Civil, fundada no princípio do artigo 1382 do Código Civil francês. Esta 
parte do curso de Direito Privado - inteiramente colocado sob a égide da responsabilidade moral - é um produto acadêmico, um produto de extravasamento do espírito de sistema, alicerçada sobre o modelo das construções da escola histórica alemã, ressentindo-se da influência da filosofia Kantiana.

Ressalte-se que a existência da responsabilidade por culpa, como assinala Geneviève Viney, da Universidade de Paris, deve-se aos canonistas, para quem a responsabilidade era antes de tudo destinada a moralizar as condutas individuais, e não assegurar a reparação do dano”. (Machado, 2000, p.317-318).

A responsabilidade, hoje, é enfocada como um dever do homem contemporâneo, dever este que se alastra tanto para o aspecto moral como para o jurídico.

Escreveu Vasquez (1989):

"O homem é livre de decidir e agir, sem que a sua decisão e a sua ação deixem de ser causadas. Mas o grau de liberdade está por sua vez, determinado histórica e socialmente, pois se decide e se age numa determinada sociedade, que oferece aos indivíduos determinadas pautas de comportamento e de possibilidades de ação". Concluiu, ibidem:

“... vemos que a responsabilidade moral pressupõe necessariamente certo grau de liberdade, mas esta, por sua vez, implica também inevitavelmente a necessidade causal. 
Responsabilidade moral, liberdade e necessidade estão, portanto, entrelaçadas indissoluvelmente no ato moral' (Vasquez, 1989, p.113).

Problematizar responsabilidade moral será relacionar, estreitamente, necessidade e liberdade humanas, pois somente admitindo que o agente tem certa liberdade de opção e de decisão é que se poderá responsabilizálo pelos seus atos.

A amplitude do aspecto moral terá como somatória o comportamento do indivíduo e seu convívio social num dado momento histórico.

Recordou Stoco (1997) que a responsabilidade não é fenômeno exclusivo da vida jurídica, antes se liga a todos os domínios da vida social. Portanto, concluiu o autor, a responsabilidade é resultado da ação pela qual o homem expressa o seu comportamento, em face desse dever ou obrigação.

Escreveu Marques (1994) que foi decisiva a contribuição dos doutrinadores alemães das décadas de cinqüenta e sessenta, que introduziram uma visão dinâmica e total de obrigação, de um processo complexo, verdadeiro feixe ou conjunto de deveres que vinculam as partes desde a sua aproximação negocial (momento pré-contratual) e continuarão vinculado-as mesmo depois de cumprido o dever principal (pós-eficácia dos contratos). A autora relembrou a figura criada por Karl Larenz, segundo a qual a 'obrigação' seria como um objeto material que projeta necessariamente uma sombra, a qual chamamos de 'responsabilidade'. 
Já o aspecto jurídico terá como abrangência a responsabilidade penal e civil. A própria legislação brasileira admite independência entre a responsabilidade penal e civil em seu Código Civil (Brasil, 1986a), cujo Artigo 1525 diz:

"A responsabilidade civil é independente da criminal; não se poderá, porém, questionar sobre a existência do fato, ou quem seja seu autor, quando estas questões se acharem decididas no crime”.

É na responsabilidade civil que encontramos uma determinação genérica na qual danos devem ser reparados. Determina o Artigo 159 do Código Civil Brasileiro (Brasil, 1986a), in verbis:

"Aquele que, por ação ou omissão voluntária, negligência ou imprudência, violar direito ou causar prejuízo a outrem, fica obrigado a reparar o dano".

A partir da idéia de ato ilícito, trazida pelo citado Artigo 159, e reportando à doutrina brasileira, considera Dias que culpa é:

“... a falta de diligência na observação da norma de conduta, isto é, o desprezo, por parte do agente, do esforço necessário para observá-la, com resultado, não objetivado, mas previsível, desde que o agente se detivesse na consideração das conseqüências eventuais da sua atitude" (Dias, 1979, p.136-137). 
Quanto a Monteiro (1982), entende ele que culpa é “... a violação de um dever que o agente podia conhecer e acatar".

Por sua vez, Pereira (1997) define a culpa como “... erro de conduta, cometido pelo agente que, procedendo contra direito, causa dano a outrem, sem a intenção de prejudicar, e sem a consciência de que seu comportamento poderia causá-lo".

Portanto, a culpa é a violação de um direito por um fato imputável, mas praticado sem a intenção de prejudicar.

O Artigo 1545 do mesmo Código (Brasil, 1986a) esposou inteiramente a teoria da culpa, no que diz respeito à responsabilidade profissional:

"Os médicos, cirurgiões, farmacêuticos, parteiras e dentistas são obrigados a satisfazer o dano, sempre que da imprudência, negligência ou imperícia, em atos profissionais, resultar morte, inabilitação de serviço ou ferimento".

Escreveu Vasconcelos (1970) que a responsabilidade do médico poderá ser enquadrada nos artigos 159,1525 e 1545 do CCB. Preconizou as sanções da lei nas faltas graves, sobretudo aquelas que encerram e denotam imperícia desdenhosa, ignorância voluntária, má-fé, desprezo pelo sofrimento alheio ou as que impliquem desonestidade profissional. 
Havendo dano - morte, incapacidade ou ferimento - a vítima deve provar que o profissional agiu com culpa stricto sensu, ou seja, com imperícia, imprudência ou negligência, para poder ser ressarcida.

A negligência é caracterizada pela omissão do agente no desenvolvimento de determinado ato.

Segundo França (1978) apud Kfouri Neto (1990), a negligência médica “... caracteriza-se pela inação, indolência, inércia, passividade. É a falta de observância aos deveres que as circunstâncias exigem. É um ato omissivo" (Kfouri Neto, 1990, p.65).

Comentou Oliveira (1999):

“Apenas para exemplificar melhor a questão, pode-se trazer alguns exemplos de conduta negligente do odontólogo, como é o caso da negligência do responsável por estágio curricular, que permite a prática ilegal da profissão por estudantes de odontologia; da falta de cuidados de assepsia do material utilizado nos pacientes; ou do dentista que deixa de atuar ou encaminhar a profissional habilitado o paciente que necessita de urgente intervenção cirúrgica.

De igual forma, é negligente o dentista que prescreve medicação por telefone, sem o necessário contato com o paciente, ou aquele que deixa de promover a manutenção periódica em seu equipamento dentário, causando a quebra do mesmo no meio de uma intervenção e danos para o paciente" (Olivieira, 1999, p.107).

A imprudência, por sua vez, é a falta de diligência, a falta de cuidado necessário para a prática de determinado ato. 
Escreveu Kfouri Neto, op.cit., p.65, "age com imprudência o profissional que tem atitudes não justificadas, açodadas, precipitadas, sem usar a cautela."

Esclareceu Oliveira, op.cit., p.109:

"É imprudente, de igual forma, o odontopediatra que resolve fazer cirurgia buco-maxilo-facial, ou põe-se a fazer implante sem a necessária especialização.

Inclui-se aqui também o profissional que, podendo utilizar-se de técnica eficaz e conhecida, decide utilizar-se de método experimental, causando, assim, ao paciente um resultado danoso."

No campo da casuística, o tribunal de Justiça do Estado de São Paulo já caracterizou imprudência de dentista que utiliza técnicas cirúrgicas não aprovadas pela comunidade científica:

“Indenização - Responsabilidade civil - Ato ilícito - Danos decorrentes de cirurgia ortodôntica - Imprudência pelo uso de técnicas cirúrgicas não aprovadas pela comunidade científica e imperícia em virtude do comprometimento de enervações e da estrutura óssea - Ação procedente - Recurso não provido - Voto vencido." (TJSP - 1a C. Ap. - Rel. Álvaro Lazzarini - j. 19/4/88 RJTJESP 121/90).

Oliveira, em seqüência, destacou:

"A odontologia comporta métodos diferentes para o mesmo tratamento e esta opção apenas pode ser feita pelo profissional. 0 
fato de um dentista utilizar-se de tratamento não usual não significa tenha o mesmo agido com imprudência, desde que tal método seja aceito cientificamente, ainda que de maneira minoritária.

No entanto, sempre que a opção terapêutica possa causar resultados diferentes, deve o dentista obter a permissão do paciente ou seu responsável para a realização da intervenção" (Olivieira, 1999, p.110). Comentou Calvielli que o dever profissional é o exercício de realizar o trabalho convencionado de acordo com um determinado volume de conhecimentos técnicos e científicos. Alertou:

"Há que se considerar, porém, e é muito importante que o façamos neste momento, o exame das condições socioeconômicas vividas pela população brasileira, das suas condições bucais e da interpenetração dessas duas realidades na condução do tratamento odontológico, tendo em vista as alternativas oferecidas pela odontologia no que tange a multiplicidade de técnicas e de materiais restauradores." (Calvielli in Silva, 1997, p.403).

Imperícia, define Kfouri Neto, op.cit., “...é a falta de observação das normas, deficiência de conhecimentos técnicos da profissão, o despreparo prático."

Para Oliveira, op.cit., imperícia é a falta de aptidão ou habilidade para fazer alguma coisa da qual o agente, em razão de sua profissão ou atividade, não poderia falhar na sua execução.

A própria jurisprudência relata casos de clara imperícia, considerados como negligência pelos tribunais. O Tribunal de Alçada Criminal de São 
Paulo, em acórdão relatado pelo Juiz Nogueira Filho, posicionou-se a respeito do assunto:

"Age com grau de culpa acentuadíssimo, na modalidade de negligência, o cirurgião dentista que, ao extrair o dente do siso da vítima, dá causa a fratura do osso mandibular, acarretando debilidade permanente da função mastigatória e deformidade permanente, em função de não ter tomado providências cabíveis à constatação do sucesso da extração."

Oliveira comentou o acórdão:

"Em que pese a segurança na afirmação, entendemos que a fratura do osso mandibular, durante o processo de extração de dente, caracteriza sim a imperícia do dentista e não sua negligência porque, como vimos, trata-se de um comportamento omisso do agente." (Oliveira, 1999, p.114).

Avecone (1981), apud Kfouri Neto (1996), exemplificando a diferença entre a imperícia e a negligência, no caso específico do dentista, asseverou: "Assim, como um dentista que não pergunta a quem se submete a tratamento se é diabético: se desconhece as graves conseqüências às quais expõe o paciente, imperito em sumo grau; se, ao contrário, por esquecimento ou pressa, tenha deixado de interpelá-lo, é negligente. A diligência exigível, já se disse, é a mediana, do homem normal, não se podendo exigir do médico dotes 
tão elevados que o façam adentrar ao conceito de 'excepcionais' " (Kfouri Neto, 1996, p.75).

As referidas modalidades de culpa não excluem umas às outras e, muitas vezes, em verdade, se confundem. A imperícia, no entanto, é a forma mais comum na atividade do cirurgião dentista ou de qualquer outro profissional dentro do campo da responsabilidade civil aquiliana.

Oliveira citou que o Tribunal de Alçada do Estado de Minas Gerais condenou dentista especializado em ortodontia pela utilização de material e aparelho fisioterápico inadequados, ressaltando que a habilitação legal, por si só, não autoriza a prática da ortodontia, sendo imprescindível a detenção dos conhecimentos técnicos necessários para o exercício da especialização:

"Responsabilidade Civil - Dentista - Ortodontia - Habilitação Prestação de serviço - Cláusula contratual - Processo disciplinar Responde civilmente pelos danos resultantes de tratamento ortodôntico o profissional que utiliza material e aparelho fisioterápico inadequados, visto que tal responsabilidade decorre da imprudência ou imperícia no exercício da profissão - A habilitação legal, por si só, não autoriza a prática da ortodontia, sendo imprescindível, ainda, a detenção de conhecimentos técnicos obtidos por meio de especialização - Nos contratos de prestação de serviços odontológicos e médicos, considera-se implícita a cláusula de incolumidade do paciente, consistente no dever de cumprimento da obrigação sem produção de dano ou agravamento de sua saúde, ressalvando-se as hipóteses em que tal risco seja necessário, desde 
que haja prévia anuência daquele ou de seus familiares - $A$ absolvição do profissional em processo disciplinar, instaurado junto ao órgão de classe a que pertence, não vincula qualquer decisão judicial' (Oliveira, 1999, p.115).

Assim posto, entende-se juridicamente que o cirurgião dentista deve reparar o dano. Cabe, aqui, salientarmos que a reparação poderá ser pecuniária, bem como a recomposição do status quo ante.

Abordando a responsabilidade profissional do cirurgião dentista, Arbenz asseverou que "conquanto a responsabilidade profissional do médico, e por extensão a do cirurgião dentista, nem sempre tenha sido recebida com aplausos, até pelo contrário, repudiada, a verdade é que ela constitui uma necessidade" (Arbenz, 1959, p.57).

Menezes (1994), na caracterização da responsabilidade odontológica, valendo-se de Nério Rojas quando examina a responsabilidade médica, definiu como requisitos indispensáveis:

$\checkmark$ agente - É necessário que o profissional esteja legalmente habilitado para exercer a Odontologia.

$\checkmark$ O ato - Deverá constituir-se o resultado danoso de um ato lícito da profissão. Ações criminosas de outra natureza quando praticadas por cirurgiões dentistas, embora que no ambiente de trabalho e no exercício da profissão, sujeitam-se à sanção de outros artigos do Código Penal referentes aos crimes em geral. 
$\checkmark$ A ausência de dolo - Trata-se da culpa profissional, praticada sem intenção de prejudicar, nas condições consagradas juridicamente: imprudência, negligência ou imperícia.

$\checkmark$ O dano - É imprescindível que seja constatada a existência de dano efetivo, real e concreto. Este elemento objetivo constitui-se uma condição indispensável para a caracterização do crime de responsabilidade profissional, possibilitando, outrossim, que, de acordo com sua intensidade, seja determinado o grau de indenização ou da pena.

$\checkmark$ nexo causal - A constatação do nexo de causa e efeito é indispensável. A existência de uma ligação de dependência entre o dano e o ato profissional apontado como seu causador é, por fim, o último requisito a se observar na caracterização do crime culposo ou crime de responsabilidade profissional.

Os fatores constitutivos da responsabilidade profissional são assim resumidos por Beltran apud Leite (1962):

"1‥ O autor deve ser médico, odontólogo, farmacêutico, parteira, praticante, enfermeiro, etc.

2‥ Deve tratar-se de um ato realizado dentro da profissão.

3․ Não se requer intenção criminal. Se existir essa intenção, o delito deixa de pertencer à responsabilidade profissional.

4․ Deve existir dano no corpo ou na saúde.

5․ Esse dano deve ser conseqüência de um ato de imperícia, imprudência ou negligência do profissional. 
6‥ Deve existir uma relação direta de causa e efeito entre $o$ ato profissional e o dano sobrevindo" (Leite, 1962, p.202).

Comentou Leite, op. cit., p.202: "Não se pode, portanto, falar em crime de responsabilidade profissional quando o agente agiu com a intenção de prejudicar, incorrendo, assim, em crime doloso".

Dispõe o Artigo 18 do Código Penal Brasileiro (Brasil, 1986b):

"Diz-se crime:

I - Doloso, quando o agente quis o resultado ou assumiu o risco de produzi-lo;

II - Culposo, quando o agente deu causa ao resultado por imprudência, negligência ou imperícia.

Parágrafo único - Salvo os casos expresso em lei ninguém pode ser punido por fato previsto como crime, senão quando o pratica dolosamente".

Afirmou Bevilaqua (1954):

“... ato ilícito é a violação do dever ou o dano causado a outrem por dolo ou culpa. O dolo consiste na intenção de ofender o direito ou prejudicar o patrimônio por ação ou omissão. A culpa é a negligência ou imprudência do agente, que determina violação de direito alheio ou causa prejuízo a outrem. Na culpa há, sempre, a violação de um dever preexistente. Se esse dever se funda em um contrato, a culpa é contratual; se no princípio geral de direito que 
manda respeitar a pessoa e os bens alheios, a culpa é extracontratual ou aquiliana".

Em sua obra Medicina Legal, Silva (1972) escreveu:

"O médico faz perguntas, exige a realidade; entra no mais fundo da vida do doente. Desnuda-lhe a alma antes de fazê-lo ao corpo, para examinar-Ihe o organismo.

Da parte do doente, há de haver a maior exatidão; da parte do médico, justo é que se Ihe exija, conseqüentemente, a mais completa discrição. É um contrato de locação de serviços entre o que narra e o que indaga. Não importa que não exista nenhum documento escrito, comprovando a prestação desses serviços. O simples fato de o médico admitir o doente, começando o tratamento ou atendendo a um chamado, já dá origem ao contrato, seja diretamente com o doente, seja com pessoas de sua família ou qualquer outra" (Silva, 1972, p.69).

No que diz respeito ao referido contrato, Dias (1979) foi incisivo:

"Ora, a natureza contratual da responsabilidade médica não nos parece hoje objeto de dúvidas. (...) Acreditamos, pois, que a responsabilidade do médico é contratual, não obstante sua colocação no capítulo dos atos ilícitos."

Kfouri Neto (1996) escreveu: "Apesar do CCB colocar a responsabilidade médica dentre os atos lícitos, não mais acende controvérsias caracterizar-se a responsabilidade médica como ex contratu." 
Discorrendo sobre a natureza da responsabilidade civil do médico, Theodoro Júnior (1999) contextualizou: “Hoje, pode-se afirmar, sem medo de erro, que a responsabilidade civil do médico, sem embargo de ter sido tratada pelo legislador entre os casos de atos ilícitos, é vista unanimemente como responsabilidade contratual." Ao final do parágrafo citou Aguiar Dias, Miguel Kfouri Neto e Sílvio Rodrigues. Abordou ainda a possibilidade do médico vir a incorrer em responsabilidade extracontratual quando acontecer a prestação profissional em situação emergencial, sem antes ter havido qualquer acordo de vontades entre o paciente e o facultativo.

Oliveira, ao abordar a natureza da responsabilidade civil odontológica, escreveu:

"Alguns autores defendem a distinção entre a culpa contratual e a culpa extracontratual, afirmando serem ambas institutos diferentes, ao ponto de afirmar que o termo responsabilidade apenas é adequado à culpa aquiliana, ao passo que a culpa contratual deveria adotar o nome de garantia" (Oliveira, 1999, p.116).

O autor comentou que, apesar de reconhecer as diferenças existentes entre elas, culpa contratual e culpa extracontratual, entende que as mesmas não são relevantes por não atingirem os princípios fundamentais da responsabilidade civil. Destacou que a culpa extracontratual deriva do Artigo 159 do CCB, ou seja, da prática de um ato ilícito em que o agente infringe um dever legal, ao passo que na contratual descumpre-se o acordado entre as partes. Fundamentou legalmente a culpa contratual pelo disposto nesse Código, Artigos 956 e seguintes e 1056 e seguintes. 
Concluiu afirmando que a responsabilidade civil do cirurgião dentista possui, fundamentalmente, natureza contratual, muito embora não se possa esquecer os casos em que esta relação não é abrangida pelo contrato tornando-se, assim, aquiliana.

Calvielli enfatizou que muito se discutiu sobre se a relação estabelecida entre o médico (e por analogia, o cirurgião dentista) e seu paciente era contratual ou extracontratual. Comentou que:

"Essa discussão, embora de certa forma pacificada pela doutrina (Costa, 1928; Dias, 1983; Diniz, 1988; Pedrotti, 1995) que a entende como contratual, adquire extrema relevância para a odontologia, na medida em que dela decorre a conceituação da natureza da obrigação contratual, que pode ser de meio ou de resultado" (Calvielli in Silva,1997, p.401).

Expôs Graça Leite (1962) que tanto o cirurgião dentista como o médico não assumem a obrigação de resultado, e sim a obrigação de meio. Asseverou o autor que, desde que o tratamento se tenha realizado dentro das regras científicas em voga, o insucesso terapêutico não constitui nenhuma culpa profissional, por mais decepcionante que o fato seja. Opinou, assim, que o cirurgião dentista somente se obriga a diligenciar os meios de obter a cura, mas não se obriga a efetivar a cura.

Bittar (1991) e Araújo (1991) acreditaram que a obrigação do cirurgião dentista é a de resultado. Afirmaram que a Odontologia, na maioria dos casos, possui condições de garantir um resultado positivo, responsabilizando os avanços tecnológicos na área. 
Diniz (1990) comentou ser bastante controvertida a questão da natureza jurídica da responsabilidade profissional. Entende a autora que os profissionais liberais quando se vinculam à prestação de seus serviços, citando, por exemplo, o advogado, o médico, o dentista, se aplicam as noções de obrigação de meio e de resultado, que partem de um contrato. Concluiu ser contratual a responsabilidade decorrente de infração dessas obrigações. Comentou em sua obra:

“... A obrigação de meio é aquela em que o devedor se obriga tão somente a usar de prudência e diligência normais na prestação de certo serviço para atingir um resultado, sem, contudo, se vincular a obtê-lo. Infere-se daí que sua prestação não consiste num resultado certo e determinado a ser conseguido pelo obrigado, mas tão somente numa atividade prudente e diligente do devedor, ou seja, os meios tendentes a produzir o escopo almejado, de maneira que a inexecução da obrigação se caracteriza pela omissão do devedor em tomar certas precauções, sem se cogitar do resultado final' (Diniz, 1990, p.201).

Na obrigação de meio, o profissional coloca seus conhecimentos em prática usando prudência e diligência na prestação de serviços, sem, contudo, vincular tais conhecimentos à obtenção de resultados satisfatórios. A própria atividade profissional caracterizará procedimentos direcionados à cura, sem se cogitar resultados finais.

Já a "obrigação de resultado é aquela em que o credor tem o direito de exigir do devedor a produção de um resultado, sem o que se terá 
o inadimplemento da relação obrigacional. Tem em vista o resultado em si mesmo, de tal sorte que a obrigação só se considerará adimplida com a efetiva produção do resultado colimado. Ter-se-á a execução dessa relação obrigacional quando o devedor cumprir o objetivo final. Como essa obrigação requer um resultado útil ao credor, o seu inadimplemento é suficiente para determinar a responsabilidade do devedor, já que o resultado não seja atingido para que o credor seja indenizado pelo obrigado, que só se isentará de responsabilidade se provar que não agiu culposamente. Assim, se inadimplida essa obrigação, o obrigado ficará constituído em mora, de modo que Ihe competirá provar que a falta do resultado previsto não decorreu de sua culpa, mas de caso fortuito ou força maior, pois só assim se exonerará da responsabilidade; não terá, porém direito à contraprestação." (Diniz, 1990, p.202).

$\mathrm{Na}$ obrigação de resultado, o profissional obrigar-se-á a um determinado fim porque objetivará a própria consecução do resultado desejado.

Kfouri Neto (1990), abordando a natureza da responsabilidade médica, comentou “... Ao assistir o cliente, o médico assume uma obrigação de meio, não de resultado. (...) O médico deve apenas esforçar-se para obter a cura, mesmo que não a consiga." Por sua vez, caracterizou como obrigação de resultado a cirurgia plástica estritamente estética, na qual o profissional obriga-se a um determinado fim, pois o que interessa é o resultado dessa atividade, sem o que não terá cumprido a obrigação. 
França (1993), ao avaliar casos de processos civis e criminais e laudos elaborados por peritos, casos esses que envolvem responsabilidade dos cirurgiões dentistas, concluiu que o número de processos contra cirurgiões dentistas nos Foros Cível e Criminal vem aumentando acentuadamente nos últimos anos, tanto no Brasil como em outros países. Os casos analisados incidiram, em sua maioria, nas especialidades de Implantodontia, Prótese, Ortodontia, Endodontia e Periodontia. A autora concluiu que a responsabilidade civil do cirurgião dentista não pode ser considerada, genericamente, como responsabilidade de resultado. Considerou como responsabilidade de resultados as seguintes especialidades: Prótese em geral, Ortodontia, Dentística, Radiologia, Estomatologia, Odontologia em Saúde Coletiva e Patologia. Como responsabilidade de meio são citadas as especialidades de: Endodontia, Periodontia, Implantodontia e Cirurgia e Traumatologia Buco-Maxilo-Facial. Na Odontopediatria, ficou condicionante a área de atuação do profissional para considerar responsabilidade de meio ou de resultado.

Ronchi (1993) abordou a responsabilidade profissional na prática ortodôntica. Escreveu que a opinião comum é aquela de reconhecer o tratamento ortodôntico como obrigação de meio. Nos casos mais simples, como o de rotações dentárias isoladas, é considerada a obrigação de resultado, independente do material empregado. O erro do dentista pode ser verificado já na fase diagnóstica. O autor considerou importante a abordagem ampla, quando da anamnese. Exemplificou casos em que a responsabilidade profissional poderá ser apurada por imperícia, imprudência 
ou negligência: ingestão ou aspiração de bandas ortodônticas ou de aparelhos removíveis mal adaptados. Forças ortodônticas incongruentes poderão ocasionar pulpites, necrose pulpar, periodontopatias, etc. A falta do controle periódico poderá causar complicações, assim como a falta da esterilização do instrumental poderá provovar a transmissão de patologias infecciosas. Entre os fatores que podem influir sobre o resultado do tratamento ortodôntico, citou:

$\checkmark$ Processos infecciosos.

$\checkmark$ Obstruções nasais.

$\checkmark$ Endocrinopatias.

$\checkmark$ Colágenopatias.

Salientou que a falta da colaboração do paciente, a falta da higiene oral, a falta da manutenção do aparelho e o desrespeito às horas mínimas de aplicação do mesmo, poderão prejudicar a correta evolução do tratamento ortodôntico.

Em 1997, Stoco enfatizou que “... a obrigação de resultado mais se evidencia quando se cuide de tratamento dentário que envolva a colocação de prótese, restauração, limpeza, etc., voltadas para o aspecto estético" (p.172).

Sobre esse resultado, Calvielli escreveu:

“... a obrigação contratual do cirurgião dentista compreende, fundamentalmente, a realização do serviço convencionado (e que consiste no seu plano de tratamento) que poderá ser considerada 
cumprida, em determinados casos, se o profissional agiu com zelo e diligência (obrigação de meio)" (Calvielli in Silva,1997, p.402-403).

Em outros casos, comentou a autora, somente o resultado esperado desobrigará o profissional.

Prux (1998) abordou um novo enfoque quanto à responsabilidade do profissional liberal. Após examinar constatações preliminares que são de manejo usual na doutrina, apresentou o desenvolvimento da sua teoria, a qual se compõem basicamente das seguintes conclusões:

- "A teoria da culpa não é adequada para ser aplicada em todos os casos de responsabilidade civil de ordem pessoal dos profissionais liberais. Nas obrigações 'de resultado', ela se revela inadequada e, nas agressões aos direitos dos consumidores que são perpetradas através de condutas e práticas de mercado (na oferta, na propaganda enganosa, na cobrança de dívidas, no uso de práticas e cláusulas abusivas, etc.) ela se revela, além de inadequada, quase impertinente. Exemplo: por dispositivo expresso do Código de Defesa do Consumidor (Artigo 38), havendo publicidade/propaganda que seja enganosa, quem tem de provar a veracidade da mesma é o fornecedor, logo a teoria subjetiva fundada na demonstração antecipada da culpa por parte de quem a causa, revela-se, nesse caso, ser totalmente inadequada e até impertinente.

- Partimos, então, para a fórmula prática destinada a resolver a questão. Como ponto de partida, deve-se encetar um exame 
prévio do caso, a fim de apurar se a obrigação que o profissional assumiu ao contratar é de meio ou de resultado.

Em sendo de meio, a responsabilização deverá fazer-se respeitando os critérios estabelecidos pela teoria subjetiva, ou seja, com a demonstração antecipada da culpa do profissional.

Em sendo de resultado, a inversão do ônus da prova deverá ser obrigatória, devendo o profissional liberal responder com a presunção antecipada de culpa, fórmula cujos efeitos práticos são idênticos aos da responsabilidade objetiva que é aplicada pelo Código de Defesa do Consumidor aos demais fornecedores.

- Para concluir essa exposição sumária, deve-se acrescentar as seguintes observações: sempre que a obrigação contratada puder ser dividida, sendo parte dela classificada como de meio e parte como de resultado, quando da apuração da responsabilidade pelo não cumprimento, deve-se aplicar a cada uma os critérios correspondentes, conforme o já explicado. E mais, caso o cumprimento da parte de resultado, seja absolutamente fundamental para o contexto da obrigação, a responsabilização deverá acontecer inexoravelmente, a menos que o fornecedor demonstre que a cumpriu. (...) Para apurar a responsabilidade do fornecedor quanto à maior ou menor qualidade técnica, vale a teoria subjetiva fundada na culpa; de outro lado, nos itens referentes às obrigações de 
resultado, presume-se a culpa do fornecedor." (Prux, 1998, p.188-189).

Prux, ibidem, salientou que é extremamente difícil, senão impossível, arrolar especificamente todas as obrigações de resultado. Justificou que tal observação deve-se ao progresso da técnica, condutor da própria multiplicação do número dessas obrigações. Concluiu que o direito não deve se preocupar em fixar com precisão o elenco exato das obrigações consideradas de resultado, isso porque:

1. Com o passar do tempo há um aumento satisfatório do número das obrigações consideradas de resultado.

2. Tal qual a sociedade almeja, no futuro, a técnica há de permitir que quase todos os serviços contratados possam ser efetivamente garantidos (grifo nosso).

Enfocando a natureza do contrato médico, Theodoro Júnior (1999) expôs:

"O contrato médico apresenta-se, dentro do quadro geral das obrigações negociais, como um contrato de prestação de serviços, que não se rege pela legislação do trabalho, porque versa sobre atividade de profissional liberal. A prestação devida é, da parte do médico, o serviço correspondente à sua formação técnica, e, da parte do cliente, é o pagamento dos honorários correspondente ao serviço prestado" (Theodoro Júnior, 1999, p.42).

Entende o autor, ibidem, que a configuração do contrato de meio é a regra em tema de prestação de serviços médicos. Todavia, complementou 
Theodoro Júnior, há algumas situações em que a dita prestação se torna obrigação de resultado, tais como: na realização de raios $X$; de exames laboratoriais; de cirurgia plástica puramente contratual, que por si só justifica a responsabilidade indenizatória pelo dano causado ao paciente.

Oliveira (1999) apresentou um quadro de especialidades odontológicas a partir de sua natureza obrigacional:

\begin{tabular}{|c|c|}
\hline ESPECIALIDADE & NATUREZA OBRIGACIONAL \\
\hline Dentística Restauradora & Resultado \\
\hline Ortodontia & Resultado \\
\hline Patologia Bucal & Resultado \\
\hline Prótese Dentária & Resultado \\
\hline Odontologia em Saúde Coletiva & Resultado \\
\hline Radiologia & Resultado \\
\hline Endodontia & Resultado \\
\hline Cirurgia Traumatologia Buco-Maxilo-Facial & Meios \\
\hline Odontologia Legal & Resultado e Meios \\
\hline Odontopediatria & Resultado e Meios \\
\hline Periodontia & Resultado e Meios \\
\hline Prótese Buco-Maxilo-Facial & Resultado e Meios \\
\hline Estomatologia & Resultado e Meios \\
\hline Implantodontia & Resultado e Meios \\
\hline
\end{tabular}

Esclareceu o autor, op. cit., que para melhor compreensão desse posicionamento, deve-se compreender a extensão do trabalho de cada 
especialidade, cuja definição e regulamentação encontram-se nos Artigos 39 a 75, da Consolidação das Normas para Procedimentos nos Conselhos Regionais de Odontologia, estabelecida pela Resolução CFO 185/93.

Crosby \& Crosby (1987) comentaram que um entre doze ortodontistas poderá estar sujeito a um processo jurídico por tratamento inadequado, segundo a Companhia Norte-Americana de Seguros MEDICAL PROTECTIVE CO. Relataram os autores que é legalmente perigoso o ortodontista dar garantias de resultado. Passaram informações pertinentes ao tempo para reclamações à justiça, o qual varia conforme o Estado Americano, sendo normalmente de dois anos. Por reclamação de contrato, esse tempo é de quatro anos. Porém, em Illinois, foi aceita uma reclamação após dez anos, por causa da garantia dada por escrito.

Após estudarem diversos processos jurídicos que envolvem ortodontistas, os autores recomendaram algumas condutas:

- guardar registros acurados e mantê-los após o tratamento;

- cuidado e diligência no diagnóstico;

- evitar escrever implicando garantias;

- escrever plano de tratamento formal;

- obter registros completos antes do tratamento;

- manter cuidados próprios e diligência durante o tratamento;

- ter o consentimento para o tratamento assinado e arquivado;

- guardar os registros sobre a cooperação do paciente;

- indicar somente especialistas qualificados;

- seguir regras odontológicas do Estado. 
Machen (1992) abordou diversos aspectos legais na ortodontia. Apresentou uma estatística em que $47 \%$ dos processos contra ortodontistas estariam baseados numa deficiente interação entre o ortodontista e sua equipe com o paciente ou os pais; $40 \%$ dos processos seriam iniciados a partir do resultado crítico de um segundo ortodontista; aproximadamente 6\% seriam em represália a procedimentos em conjunto e somente $3 \%$ oriundos da insatisfação do paciente com os resultados do tratamento ortodôntico. Comentou a principal razão que levaria o paciente a desencadear uma ação: seria a falta de informação sobre o progresso ou não do tratamento ortodôntico - uma indisposição por parte do ortodontista em falar com o paciente ou responsável acerca dos vários problemas ou aspectos que possam haver, e um estilo de confrontação ao invés de conciliação quando algum problema ocorre.

Alertou o autor que, ibid., se uma vasta maioria de casos de má prática ortodôntica são iniciados por outras razões que não o resultado do tratamento, é incumbência do ortodontista desenvolver uma postura de interação com os pacientes e pais, demonstrando assim uma preocupação com o tratamento e o bem estar dos mesmos. Concluiu que, se isso for feito, os pacientes estarão substancialmente menos inclinados a iniciar uma demanda. Aconselhou os seguintes caminhos para se evitar o litígio:

1. Tempo extra na preparação de registros de diagnóstico.

2. Maior qualidade na discussão sobre o consentimento formal.

3. Documentação adequada e registros de tratamento.

4. Diálogo com os pacientes e pais. 
No tocante às radiografias, Cardozo (1993) salientou constituírem documentos de comprovação objetiva, representando excelente meio de prova. Porém, alertou a autora, tem-se verificado que, freqüentemente, existe um desconhecimento do valor legal desses documentos, seja por parte do clínico, seja por parte das instituições hospitalares.

Pueyo et al. (1994) relataram atuações profissionais das quais se deriva, com mais freqüência, a exigência da responsabilidade profissional na odontologia. Dentre esses relatos, destacam-se:

$\checkmark$ Erros de diagnóstico.

$\checkmark$ Não obtenção de resultados. Escuta-se cada vez mais a frase: "Não é isto o que eu queria".

$\checkmark$ Falta de consentimento.

$\checkmark$ Documentos incorretos.

Louzã, in Segre \& Cohen (1995), esclareceu que documentos médicos são diariamente elaborados, redigidos e guardados pelo médico. Preconizou que as fichas clínicas, os arquivos ou prontuários médicos constituem elemento fundamental para a prática clínica quotidiana, pois neles estão guardadas todas as informações sobre os pacientes. Salientou:

"Toda documentação guardada nestes arquivos será também muito útil nos casos em que houver a imputação de erro médico, pois, nestes casos, muitas vezes apenas o prontuário médico pode fornecer as provas necessárias para a defesa do acusado".

O autor, ibid., ao distinguir fichas clínicas da prática privada de prontuários hospitalares e outras instituições, definiu: 
"As fichas clínicas dos pacientes da clínica privada, (profissional liberal autônomo), as quais o médico deve redigir e arquivar, a ele pertencem, e por elas ele é responsável. Esta responsabilidade diz respeito principalmente ao sigilo profissional e portanto à sua guarda" (Louzan, in Segre \& Cohen, 1995, p.161).

Enfocando a relação médico/paciente, Gonçalves escreveu:

"Não há nada emocionalmente mais perturbador para um médico do que ser citado num julgamento por erro médico. Um processo pode levar o médico a isolamento pessoal, humilhação, depressão e mesmo a doença física" (Gonçalves, 1997, p.7).

O autor caracterizou os dois fatores mais importantes na profilaxia da denúncia contra o médico: a qualidade do atendimento e a habilidade de comunicação interpessoal. Comentou que muitas denúncias por erro médico são feitas quando nenhum lapso na qualidade de atendimento ocorreu ou mesmo quando não houve evidência de lesão médica. Caracterizou como fator decisivo, para levar o paciente a processar o médico, a falha na comunicação entre pacientes e médicos.

No aspecto clínico, comentou Silva, a formação profissional e a vasta literatura odontológica oferecem os subsídios necessários para a elaboração da documentação odontológica. Ao enfocar os aspectos administrativos e legais, alertou:

“... a documentação de todas as fases da atuação profissional é de suma importância e estão intimamente relacionadas com o 
aspecto clínico, podendo a falta ou falha nessa documentação comprometer a sua validade sob o aspecto legal' (Silva, 1997, p.327).

De acordo com o autor, a documentação odontológica passa a revestir-se das características de um prontuário, apto a desempenhar as funções referidas.

A comissão constituída pela portaria CFO-174/92, de 7 de dezembro de 1992, que teve como incumbência elaborar anteprojeto de resolução estabelecendo as normas para confecção de fichas clínicas com determinações sobre a padronização das mesmas em âmbito nacional e o período de guarda por parte dos profissionais e clínicas particulares ou públicas, estabeleceu conclusões apresentadas sob a forma de cinco sugestões a serem incluídas na resolução:

“1. Denominação de PRONTUÁRIO ODONTOLÓGICO em substituição à designação FICHA CLÍNICA.

5. O tempo de guarda do prontuário odontológico, por parte dos profissionais e clínicas particulares ou públicas, é de dez anos após o último comparecimento do paciente, ou, se o paciente tiver idade inferior aos dezoito anos à época do último contato profissional, dez anos a partir do dia que o paciente tiver completado ou vier a completar os dezoito anos".

Maciel (1997) fez menção ao prontuário médico quando do atendimento a pacientes com elevado potencial de complicações. Escreveu 
o autor: “... um prontuário mais completo, cuidadoso, seguramente representa um valioso documento de defesa".

Segundo Calvielli, in Silva (1997), o paciente tem na ação pessoal o instrumento para haver a reparação de eventual dano decorrente de tratamento odontológico. Citou o Código Civil, em seu Artigo 177, que estabelece:

"As ações pessoais prescrevem ordinariamente em vinte anos, as reais em dez entre presentes e, entre ausentes, em quinze, contados da data em que poderiam ser propostas".

A autora comentou que é na documentação odontológica, incluídos aí o prontuário do paciente, os livros de agendamento, modelos, radiografias etc., que o cirurgião dentista poderá procurar as provas do que alegará em sua defesa. Lembrou que, se o paciente tem vinte anos para exigir reparação, parece claro que a documentação que poderá afastar a imputação deverá ser bem guardada pelo mesmo prazo pelo profissional. As provas apresentadas pelo profissional são pré-constituídas, isto é, ou são produzidas oportunamente, ou não servirão para tal fim.

Abordando o tema Prontuário Médico, Fortes (1998) citou a Resolução no 1.331/89 do Conselho Federal de Medicina (CFM). Segundo essa resolução, o prontuário consiste em um conjunto de documentos padronizados e ordenados, provenientes de várias fontes, destinados ao registro dos cuidados profissionais prestados ao paciente. Comentou o autor 
que o prontuário é legalmente propriedade física dos estabelecimentos de saúde, mas comporta informações que estão no campo do direito moral e legal dos pacientes. Evidenciou, ainda, a importância da guarda e manutenção da documentação.

A Resolução CFM no 1.331, de 21 de setembro de 1989, em seu artigo 2º, conceituou: "Após decorrido prazo não inferior a 10 (dez) anos, a fluir da data do último registro de atendimento do paciente, o prontuário pode ser substituído por métodos de registro, capazes de assegurar a restauração plena das informações nele contidas".

No que diz respeito, em particular, à prova documental, Teixeira Filho (1999) abordou o Código de Processo Civil. Nesse diploma legal, em seu Artigo 396, está definido o momento oportuno para a sua produção, que é:

a) para o autor, o da petição inicial;

b) para o réu, o da resposta.

O autor, ibidem, ainda conceituou documento: "é todo meio material idôneo e moralmente legítimo, destinado a comprovar a existência de um fato" (Teixeira Filho, 1999, p.7). 


\subsection{0 pós-tratamento ortodôntico}

Em 1919, Hawley declarou que devido à dificuldade, daria a metade dos seus honorários profissionais a alguém que se responsabilizasse pela contenção de seus casos, depois do aparelho ativo ser removido.

Em 1945, Hellmann apud Nielsen (1994), enfatizou que a contenção não é um problema separado da ortodontia, senão uma continuação do que se faz durante o tratamento. Afirmou que o ortodontista é quase ignorante dos fatores específicos que causam a recidiva e os fracassos.

Com referência ao tempo em que o paciente deva usar os aparelhos de contenção, Strang (1958) afirmou ser variável, dependendo dos seguintes fatores:

a) a idade do paciente;

b) característica da maloclusão;

c) fatores etiológicos envolvidos;

d) forma anatômica e perfeição dos tecidos envolvidos;

e) características dos processos vitais do paciente;

f) grau de perfeição resultante do tratamento ativo.

Brodie apud Riedel (1960) salientou que o ortodontista trabalha com um ser vivo, passando por constantes modificações com o avanço da idade. O crescimento, entretanto, não pode ser medido por meio de estatísticas, pois cada uma dessas crianças é um indivíduo único, seja homem ou mulher. Comentou que se o tratamento ortodôntico for em harmonia com o 
crescimento e a natureza do indivíduo, menor será a necessidade de contenção.

Segundo Reitan (1969), é fundamental conter os dentes, até que o tecido fibroso tenha se reorganizado e as camadas de novo osso tenham sido calcificadas. As fibras principais de ligamento periodontal se reorganizam após um período de oito a nove semanas e as estruturas supra-alveolares podem permanecer estiradas durante um período mais longo. Se o dente for contido por um período de dois a três meses, há menos tendência à reorganização das fibras principais, enquanto a tendência a contrair ainda existe no grupo de fibras supra-alveolares. Daí a necessidade de conter por um período de tempo maior.

Reidel (1969) evidenciou que os requisitos para contenção são decididos na fase de diagnóstico e planejamento do tratamento a ser instituído. A análise do caso ortodôntico deve incluir um plano para contenção, não como uma fase pós-tratamento separada, porém, como parte do tratamento, dependente e associado a alterações produzidas durante o tratamento. O diagnóstico correto e o plano de tratamento lógico devem visar a um equilíbrio entre função, estética e estabilidade que simplifique a contenção por aparelhos mecânicos. Por outro lado, o diagnóstico ou tratamento incorretos complicam os resultados da contenção.

Reidel (1969) e Joondeph \& Riedel (1985) salientaram que os ortodontistas não decidiram pelo tempo de uso de aparelhos de contenção. Não se comprovou, ainda, se a contenção prolongada fornece maior estabilidade. Há dificuldades em manter a contenção continuamente e em 
determinar com exatidão quantos meses ou anos e quantas horas/dia as contenções removíveis deveriam ser usadas após o tratamento ortodôntico.

Numa entrevista abordando contenção e recidiva, Reidel (1976) respondeu que a relação entre o tempo de tratamento e a estabilidade póstratamento nunca foi satisfatoriamente documentada. Preferindo utilizar o termo 'ajuste pós-tratamento', comentou que uma multiplicidade de fatores ocasiona o ajuste pós-tratamento, incluindo: musculatura, crescimento diferencial, o maquinismo das fibras periodontais, etc.

Moyers (1979), ao escrever sobre contenção, recidiva e estabilidade oclusal em ortodontia, definiu:

“...contenção é o procedimento para manter um dente recémmovimentado em posição por um período suficientemente prolongado para assegurar a manutenção da correção.

Recidiva é o termo aplicado à perda da correção alcançada pelo tratamento ortodôntico.

Estabilidade oclusal sugere a idéia de estabilidade homeostática, isto é, o sistema mastigatório deve-se auto-estabilizar após a terapia ortodôntica” (Moyers, 1979, p.389).

Em seqüência, o autor comentou: "Todas as oclusões tratadas ortodonticamente eram, talvez, estáveis antes do tratamento. Se, no final do tratamento, elas não permanecerem estáveis, é culpa do dentista." (grifo nosso). Concluiu citando os seguintes aspectos que desempenham um papel importante na consecução da homeostase oclusal:

$\checkmark$ Objetivos corretos de tratamento. 
$\checkmark$ Cuidadosa mecanoterapia.

$\checkmark$ Ajuste oclusal preciso.

$\checkmark$ Procedimentos de contenção bem escolhidos.

Haas (1980) assegurou que raramente remove uma contenção lingual fixa inferior em menos de seis anos, com um tempo de contenção inferior de, aproximadamente, seis a oito anos. Justificou que, do ponto de vista celular, o homem é um novo corpo a cada sete anos e todas as fibras de Sharpey estiradas devem estar agora relaxadas. Os terceiros molares devem ter eruptado, estar em equilíbrio para boa erupção, ou ter sido removidos. O crescimento do ramo deve ter cessado. Ademais, os Incisivos devem ter alcançado uma homeostasia com as estruturas alveolares e periodontais com as forças de oclusão e musculares existentes.

Com a intenção de descrever o tipo de tratamento e as mudanças ocorridas no pós-tratamento, Little et al.(1981) avaliaram o alinhamento ântero-inferior em sessenta e cinco casos com dez anos de pós-contenção. No estudo, foram utilizados modelos de gesso dos casos tratados durante 0 estágio da dentição permanente. Todos os casos tiveram os quatro primeiro pré-molares extraídos. Com base na amostra estudada, concluíram:

1. A resposta a longo prazo do alinhamento inferior foi variável e imprevisível.

2. Nenhuma característica, como a classificação de Angle, o tempo de contenção, a idade do paciente no início do tratamento, o sexo ou outras variáveis medidas como o alinhamento inicial ou final, a sobressaliência, a sobremordida, a largura, ou o comprimento do 
arco foi útil para predizer o resultado a longo prazo. Nenhuma das múltiplas correlações combinando essas variáveis melhorou a capacidade para predizer a estabilidade ou a recidiva a longo prazo dos casos.

3. As dimensões em largura e comprimento do arco diminuíram tipicamente após a contenção, enquanto que o apinhamento aumentou. Isso ocorreu apesar de se manter a mesma distância intercanina durante o tratamento.

4. O êxito em manter o alinhamento ântero-inferior satisfatório foi menor que $30 \%$ e, aproximadamente $20 \%$ dos casos mostraram acentuado apinhamento muitos anos após a remoção da contenção.

5. Depois da contenção, dois terços dos pacientes apresentaram alinhamento ântero-inferior insatisfatório.

Mcnamara et al. (1985) relataram ser a contenção prolongada, geralmente, acompanhada por aparelhos removíveis tipo Hawley e, ocasionalmente, com retentor lingual fixo no arco inferior.

Williams (1985) analisou, durante vinte e um anos, pacientes tratados e que não usaram contenção inferior. O autor sugeriu uma norma para o posicionamento dental, durante o tratamento ortodôntico, de modo a alcançar a estabilidade pós-tratamento no arco inferior, sem contenção. Afirmou ainda, existirem seis chaves para a oclusão, essenciais para que a contenção inferior pudesse ser eliminada: 
- Primeira Chave - O bordo incisal do Incisivo Inferior deve ser colocado um milímetro à frente da linha A-Pg.

- Segunda Chave - Os ápices dos Incisivos Inferiores devem ser posicionados distalmente às coroas. Os Incisivos Laterais mais que os Centrais.

- Terceira Chave - O ápice do Canino Inferior deve ser posicionado distalmente à coroa, usando o plano oclusal como guia.

- Quarta Chave - Os ápices dos quatro Incisivos Inferiores devem estar no mesmo plano vestíbulo-lingual.

- Quinta Chave - O ápice do Canino Inferior deve ser posicionado ligeiramente para vestibular em relação à coroa.

- Sexta Chave - Através de desgastes interproximais, transformar os pontos de contato entre os Incisivos Inferiores em superfícies de contato. Tal procedimento ajudaria a eliminar a necessidade da contenção inferior.

Segundo Proffit (1986), existem três indicações principais para o uso dos retentores fixos:

1. Manutenção da posição dos Incisivos Inferiores, durante 0 crescimento tardio e após a correção de rotações.

2. Manutenção do fechamento de diastemas.

3. Manutenção de espaço para pôntico.

Os resultados do tratamento ortodôntico são instáveis, segundo o autor; portanto, a contenção é necessária por três razões: 
1. Tecidos gengivais e periodontais são afetados pelo movimento dental ortodôntico e requerem tempo para sua reorganização, quando os aparelhos são removidos.

2. As mudanças produzidas pelo crescimento podem alterar os resultados do tratamento ortodôntico.

3. Os dentes podem estar em uma posição instável, após o tratamento, de modo que a pressão do tecido mole produza uma tendência à recidiva.

Segundo Mucha (1987), o ortodontista tende a prolongar o período de contenção naqueles casos mais severos de irregularidades dos Incisivos no início do tratamento. Conseqüentemente, quanto maior o tempo de contenção, maior é a tendência de ocorrer uma recidiva.

Little et al. (1988) avaliaram alterações no alinhamento dos incisivos inferiores durante o período de dez a vinte anos pós-contenção. Embasados nos registros de trinta e um casos, concluíram:

1. Ocorrem mudanças consideráveis durante o período dos 20 aos 30 anos de idade.

2. Dos 30 aos 40 anos de idade o processo continua, somente que em menor grau.

3. Existe uma variação acentuada entre os pacientes, na qual poucos alcançam um ponto de aparente estabilidade ao final da adolescência. Por vários anos, muitos apresentaram mudanças ativas e significativas mesmo depois de décadas da terapia ortodôntica. 
4. De 10 a 20 anos pós-contenção, o apinhamento aumentou moderadamente. Porém, o grau de mal alinhamento para cada caso não foi predictível.

5. Um fator predictível é a redução do comprimento do arco, que continua após a remoção da contenção.

6. O único caminho para assegurar um alinhamento satisfatório no pós-tratamento é com o uso de contenção fixa ou removível para sempre.

Num trabalho de revisão, Kaplan (1988) chegou à conclusão da existência de raros casos a exigirem um mínimo ou nenhum aparelho de contenção, uma vez que o ortodontista dificilmente poderá apontar o caso em que se enquadre aquele sujeito a recidivas.

Watson (1988) estudou as causas mais freqüentes responsáveis pela recidiva. Afirmou que os problemas de recidiva nos tratamentos ortodônticos constituem a exceção e não a regra. A recidiva é uma parte da ortodontia, mas felizmente é uma parte relativamente pequena. Afirmou que a análise e um plano de tratamento adequados constituem o primeiro passo para eliminar as situações de recidiva.

Little \& Riedel (1989) avaliaram trinta casos com espaços generalizados na dentição permanente. Registraram o pré-tratamento, o pós-tratamento e um mínimo de dez anos pós-contenção. Concluíram pela necessidade de instituir contenção mesmo em casos com espaços generalizados, esclarecendo que a única maneira de assegurar o 
alinhamento satisfatório pós-tratamento seria com o uso de contenção fixa ou removível, em algum grau, talvez por toda vida.

Machen (1989) temporizou que, com o passar dos anos, o cirurgião dentista clínico geral e o especialista têm vivamente se inteirado em ações legais, donde se alega o tratamento negligente como a causa de sinais e sintomas das desordens têmporo-mandibulares. Abordou alguns casos clínicos nos quais o ortodontista foi alvo de ação legal. Dividiu a temática em três cenários: a) pacientes com a presença de sinais e sintomas de desordens têmporo-mandibulares antes de iniciarem 0 tratamento ortodôntico; b) pacientes que desenvolveram os sinais e sintomas de desordens têmporo-mandibulares durante o tratamento ortodôntico; c) pacientes que desenvolveram esses problemas depois do tratamento. Nesse artigo o autor exemplificou somente o primeiro cenário. Assim, dispôs os pacientes em duas categorias:

- Categoria 1A: a história clínica, os exames e os registros não foram adequados para identificar a desordem têmporo-mandibular préexistente.

- Categoria 1B: a condição pré-existente foi diagnosticada e o plano de tratamento abordou todos os cuidados que deveriam ser adotados.

O autor comentou, ibidem, que as ações legais envolvendo os casos na categoria $1 \mathrm{~A}$ foram de difícil defesa na corte, especialmente porque existe uma vasta literatura que trata das desordens têmporo-mandibulares. 
Também sugeriu condutas que poderão auxiliar o ortodontista:

1. Incluir no histórico médico questões direcionadas a provocar respostas que o paciente normalmente não associa aos problemas dental, articular e ortodôntico, como por exemplo: dores de cabeça, torcicolos, dores no pescoço, dores auriculares ou maxilares.

2. Perante as situações acima descritas, perguntar se algum diagnóstico ou tratamento médico foi realizado.

3. Perguntar sobre todos os dentistas, especialistas e médicos visitados nos últimos cinco anos.

4. Investigar sobre neurologistas, psiquiatras e endocrinologistas visitados.

5. Incluir questões específicas no histórico dental, como por exemplo: se previamente já recebeu algum diagnóstico e/ou tratamento envolvendo desordens têmporo-mandibulares, usou alguma aparatologia noturna, já esteve em tratamento ortodôntico anteriormente.

6. Inquirir sobre dores maxilares, inflamação dentária, sensibilidade dentinária, ajustes oclusais já procedidos.

7. Solicitar ao dentista que tenha atendido anteriormente o paciente, uma sinopse do tratamento do paciente e perguntar se ele estava atento para algum problema de articulação têmporo-mandibular.

8. Investigar sobre extrações recentes, especialmente extrações de terceiros molares. 
9. Realizar detalhadamente 0 exame da articulação têmporomandibular, incluindo a extensão dos movimentos mandibulares, palpação muscular e ruídos articulares.

Ao final, o autor preconizou a elaboração do consentimento informado, devendo esse ser da forma mais detalhada e inteligível possível.

Nanda \& Nanda (1992) apresentaram considerações sobre o crescimento dentofacial na contenção e estabilidade a longo prazo. Alertaram que os resultados, obtidos logo após um longo e cuidadoso tratamento, podem ser perdidos, em maior ou menor grau, após a remoção do aparelho. Às vezes a recidiva na posição dos dentes é observada ainda durante o período em que o paciente está usando os aparelhos de contenção. Destarte, a pergunta que se fazem, pacientes e ortodontista é: por quanto tempo deve-se manter a contenção ativa com tais aparelhos?

Os autores citaram artigos recentes que avaliam o pós-tratamento ortodôntico. Os resultados demonstraram ocorrer recidiva em quase todos os casos. O tratamento ortodôntico, realizado com ou sem extrações, teve a mesma sorte. Não se encontrou uma variável que fosse predictível da estabilidade ou da recidiva. A ortodontia contemporânea não tem encontrado uma solução satisfatória frente ao problema da obtenção de estabilidade a longo prazo.

Nanda \& Nanda, op.cit., ao finalizarem suas considerações, escreveram:

“... se pode filosofar que na morfologia humana nada permanece estacionário. O envelhecimento é um processo de 
alteração bem documentado. O ajuste das dentições e as alterações nas relações dentárias são bem conhecidas, mesmo em indivíduos sãos. Então, porque se espera a estabilidade a longo prazo? Talvez a resposta a esta pergunta seja a contenção a longo prazo - dinâmica, não estática" (Nanda \& Nanda, 1992, p.301).

Baptista, in Petrelli (1993), ressaltou que o período de contenção ortodôntica é parte integrante do tratamento e, como tal, deve ser planejado. Destacou que paciente e/ou responsável devem ser informados sobre a importância dessa fase de tratamento. Escreveu que o ortodontista não deve encarar a contenção como um procedimento para manter os dentes estáticos nas posições obtidas ao final do tratamento ativo. Assim, alguns movimentos deverão ser previstos na etapa inicial de contenção.

Burstone (1994) comentou que a estabilidade deverá ser um dos maiores objetivos para o êxito do tratamento no paciente ortodôntico. Para alcançar tal objetivo, o ortodontista deverá ter conhecimentos práticos sobre a estabilidade. Quanto ao aspecto de manejar os fracassos, a medicina tem uma história melhor que a odontologia. Salientou que os médicos sabem que o paciente vai morrer, independentemente do tratamento que utilizem. Assim, na medicina, as autópsias são feitas rotineiramente para investigar a causa da morte. Em odontologia, comentou o autor, tende a se esconder os fracassos. Quando os fracassos são ignorados ou não documentados, as novas gerações de ortodontistas são educadas sucessivamente crendo que a estabilidade não é um problema. 
Ibidem, Burstone concluiu que, em última instância, a estabilidade se relaciona com as forças que atuam sobre os dentes e, portanto, é um problema neuromuscular. Nesse sentido, a morfologia é secundária. Entretanto, com as alterações morfológicas, os dentes, ossos e músculos respondem com padrões diferentes e produzem alterações nas forças que atuam sobre os dentes. Alertou que o ortodontista às vezes se preocupará sobre a estabilidade no momento de colocar os aparelhos de contenção. Entretanto, a estabilidade começa realmente com o primeiro exame clínico e inclui um bom levantamento de dados e um plano de tratamento. Finalizou que a contenção é a continuação do plano de tratamento e requer o mesmo tipo de pensamento analítico que se usa para estabelecer os objetivos específicos no início do tratamento.

Nanda \& Zernik (1994) comentaram que todo ortodontista está familiarizado com a recidiva e a necessidade de contenção. A estabilidade da oclusão depois do tratamento ortodôntico é um dos objetivos principais dos ortodontistas ao começar o tratamento. A capacidade do ortodontista para obter estabilidade a longo prazo e a compreensão dos fatores subjacentes à estabilidade podem ser as menos fundadas da tríade mencionada - a recidiva, a contenção e a estabilidade - clara indicação da necessidade de contenção dos resultados obtidos, às vezes, contenção a longo prazo. Para os autores, a falta de estabilidade da oclusão logo após um tratamento pode ser dividida em duas categorias:

$1^{\text {a }}$ - Alterações relacionadas com o crescimento, a maturação e o envelhecimento da dentição e a oclusão. 
$2^{a}$ - Alterações relacionadas com a falta de estabilidade intrínseca da oclusão, produzidas pelo tratamento ortodôntico.

Little (1994), ao escrever sobre estabilidade e recidiva do alinhamento do arco dentário, comentou:

"Ao passar do tempo, a redução das dimensões do arco inferior nas maloclusões tratadas ou não tratadas parece ser um fenômeno fisiológico normal. O grau de redução do comprimento do arco, a contração e o apinhamento resultante são variáveis e imprevisíveis" (Little in Nanda \& Burstone, 1994, p.84).

Depois de quase um século de debates, Gorman (1994) comentou que a controvérsia sobre o papel das extrações na prevenção da recidiva do tratamento ortodôntico ainda subsiste. Ortodontista clínico com muitos anos de experiência, declinou informações importantes no que tange ao póstratamento. O autor informou que, na consulta inicial, discute com o paciente a problemática da estabilidade dos incisivos inferiores no pós-tratamento e explica que os honorários profissionais incluem um ano de visitas durante o período de contenção. Se o paciente está em crescimento, controla-o anualmente. Depois de cessado o crescimento, remove a contenção e explica ao paciente o que sucede com os incisivos inferiores nas oclusões normais não tratadas. Utiliza uma analogia sugerida por Parker: “...Os dentes se movem durante toda nossa vida, assim como a cor do nosso cabelo muda ao longo da nossa vida". 
Concluiu, ibidem, que a extração de pré-molares não assegura estabilidade dos incisivos inferiores a longo prazo e, para reduzir a possibilidade de recidiva dos incisivos inferiores, desenvolveu doze chaves para a estabilidade. Porém, salientou que seguir as chaves não elimina totalmente a recidiva: "... a única forma segura de conseguir-la é indicar contenção durante toda a vida e em todos os casos". Esclareceu que isso é impossível hoje em dia devido à grande quantidade de pacientes que buscam o tratamento ortodôntico.

Sadowsky (1994) comentou que certas alterações pós-tratamento são aceitáveis e não devem preocupar. Evidenciou que as expectativas do ortodontista e dos pacientes devem ser entendidas clara e razoavelmente antes de começar o tratamento, reforçado-as durante o período de contenção (grifo nosso). As explicações para essa recidiva são muitas e bem variadas, e a capacidade do ortodontista para predizer certeiramente 0 resultado a longo prazo não é boa. Argumentou, ao final, que o paciente deve ser informado do risco potencial de recidiva e dar-lhe certa responsabilidade no controle da estabilidade a longo prazo.

Alexander (1994) preconizou que a contenção começa com o diagnóstico e o plano de tratamento. Salientou que o tratamento ortodôntico deve ter a seguinte filosofia: "Começar tendo o final em mente". Assim, quando se removem os dispositivos de contenção, se os dentes foram posicionados corretamente durante o tratamento ativo, a redução interproximal foi realizada corretamente e se resolveu a questão dos terceiros molares, a probabilidade de que o resultado permaneça estável é 
excelente. $\mathrm{O}$ autor considerou a contenção tão importante quanto o tratamento ativo para produzir um resultado excelente e duradouro. Temporizou a contenção como sendo um processo de três anos, durante o qual o clínico deve ter o controle do caso e estimular o paciente a continuar usando os dispositivos de contenção.

Em 1997, Alexander ao abordar contenção, escreveu:

"A contenção ortodôntica nasceu do medo. Os dentistas tinham medo que depois de corrigidos os dentes voltassem à posição de origem, a menos que medidas preventivas fossem tomadas. Esse temor tinha razão de ser e permanece válido até hoje. O objetivo da contenção ortodôntica é manter os dentes na posição correta, depois de retirado o aparelho, tempo suficiente para que ocorra o ajuste fisiológico do novo ambiente dental. Uma vez que ocorre esse ajuste fisiológico, é improvável que os dentes mudem de modo apreciável' (Alexander, 1997, p.431).

A filosofia do autor, ibidem, é a de que quanto maior for o tempo no qual a posição dos dentes tratados pode ser mantida, mais estável se tornará a oclusão. Abordou contenção como sendo um processo de quatro anos e comentou que o único modo de se garantir que uma contenção obtenha sucesso é aquele no qual o paciente tenha alcançado oclusão equilibrada. Preconizou que, para esperar pouca ou nenhuma recidiva póstratamento, o resultado ortodôntico deverá incluir:

$\checkmark$ Posicionamento correto dos incisivos inferiores.

$\checkmark$ Arcada inferior nivelada. 
$\checkmark$ Distância intercanina não expandida.

$\checkmark$ Boa interdigitação nos segmentos posteriores.

$\checkmark$ Ângulo interincisal apropriado.

$\checkmark$ Questão do terceiro molar resolvida.

Blake \& Bibby (1998) realizaram extensa revisão bibliográfica sobre contenção e estabilidade. Comentaram que a importância da oclusão funcional e estável no pós-tratamento é repetidamente enfatizada na literatura. Concluíram, citando autores e seus respectivos estudos (Little et al., 1998; Little, 1990; Horowitz \& Hixon, 1969), que a contenção permanente seria o único caminho para garantir por um longo período a estabilidade pós-tratamento. Porém, acrescentaram as autoras, já na formação ortodôntica o profissional deverá ser preparado para adotar procedimentos perante os fatores associados à recidiva. Preconizaram excluir dos pacientes a carga principal de evitar-se a recidiva e aconselharam manter, como objetivos do tratamento ortodôntico, os seguintes princípios básicos descritos na literatura:

1. A forma do arco inferior deve ser mantida o máximo possível durante o tratamento ortodôntico.

2. A distância original intercaninos inferiores deve ser mantida tanto quanto possível porque a expansão da mesma é a mais previsível de todas as recidivas.

3. O comprimento do arco inferior diminui com o passar do tempo.

4. A posição mais estável dos incisivos inferiores é a do prétratamento. Avançar os incisivos inferiores é instável e pode ser 
considerado como sério comprometimento da estabilidade ânteroinferior no pós-tratamento.

5. A fibrotomia é um meio efetivo na redução da recidiva rotacional.

6. A reaproximação do incisivo inferior demonstra melhor estabilidade por um longo período no pós-tratamento.

Momicchioli \& Martini (1998), após sumarizarem as bases jurídicas e jurisprudenciais da responsabilidade profissional do médico, analisaram algumas complicações iatrogênicas que poderão ocorrer durante 0 tratamento ortodôntico, dentre elas: desmineralização do esmalte, reabsorção apical, perda da vitalidade pulpar e alterações periodontais. Relataram situações particulares e imprevisíveis que poderão ser correlacionadas ao tratamento ortodôntico (endocardites, injúrias oculares provocada pelo aparelho e deglutição do aparelho). Alertaram que tais situações particulares poderão hipoteticamente responsabilizar o ortodontista. Ao final, consideraram a importância do consentimento informado na ortodontia e reportaram que, atualmente, é a primeira forma de contato entre paciente e médico, não somente no aspecto legal, mas também na necessária troca de informações concernentes ao tratamento dental e possíveis complicações futuras.

Aguiari et al. (1998) compuseram uma comissão de trabalho sobre consentimento informado e linhas guia em odontologia. Apresentaram uma versão preliminar com um modelo de consentimento informado para cada uma das especialidades da odontologia. Em relação à ortodontia, 
enumeraram diversos riscos do tratamento e preconizaram que a fase de contenção é tão importante quanto aquela da terapia ativa.

Tomando como parâmetro os postulados de Strang descritos no clássico artigo "Fatores associados ao sucesso do tratamento ortodôntico", Sachet (1999) escreveu uma monografia onde, sob a égide das pesquisas mais recentes, concluiu que o desconhecimento de alguns aspectos pertinentes à estabilidade e a dificuldade em atingir todos os objetivos são grandes razões para informar pais e pacientes sobre a possibilidade de mudanças no pós-contenção.

Conti \& Sábio (1999) revisaram diversas teorias e conceitos atuais no que tange à utilização do ajuste oclusal como método terapêutico na finalização de casos ortodônticos. Concluíram que muita controvérsia ainda persiste, porém, é de extrema importância uma avaliação correta da indicação ou contra-indicação do ajuste oclusal total ou parcial, para que o profissional não crie uma iatrogenia desnecessária ao seu paciente. Atinentes à ortodontia, os autores comentaram a necessidade de uma análise criteriosa, pois o estabelecimento de uma oclusão com os princípios gnatológicos após a terapia ortodôntica pode dispensar o ajuste oclusal, principalmente em adolescentes. Dessa forma, algum tipo de ajuste parcial poderá ser indicado como auxiliar na manutenção da estabilidade posicional pós-ortodontia. 


\subsection{O profissional liberal no Código de Defesa do Consumidor}

Temporizou Denari (1997): "De repente, neste final de século e de milênio, o homem se dá conta de que vive numa sociedade de consumo". O autor comentou que a característica mais marcante dessa sociedade é a produção em massa, fruto da revolução industrial e, mais proximamente, da revolução tecnológica. De forma singular, destacou o autor:

"A produção em massa engendrou a distribuição em massa, através da instalação de uma formidável rede de super e hipermercados em todo o território nacional, e esta última, por sua vez, engendrou o consumo em massa, apanágio da sociedade de consumo em que todos nós estamos envolvidos" (Denari, 1997, p.138).

Reportou Cáceres (1994) que a ampliação dos mercados, os avanços tecnológicos, a expansão cada vez maior das multinacionais e a influência dos meios de comunicação social que a cada dia se faz notar fazem, como regra geral, com que o consumidor individual não tenha possibilidade de defender seus interesses. Esclareceu ainda que, nesse contexto, é normal que o consumidor não esteja em condições de julgar, por si mesmo, sobre a performance dos produtos e serviços. Por essa descrição, a autora evidenciou que uma atuação sistemática de tutelar os consumidores se faz emergente.

O tema da responsabilidade civil, que de tempos para cá vem ganhando enorme relevância em virtude da complexidade cada vez maior 
das relações sociais, é de fundamental importância quando se trata de proteção ao consumidor.

Nesse sentido, historicamente, o Código de Hammurabi já mostrava a preocupação do rei pela justiça, pois suas inúmeras sentenças e decisões voltavam-se para salvaguardar o direito de seus concidadãos. No referido Código, as diversas leis casuísticas são organizadas pelo princípio de atração, pela semelhança de temas e assuntos tratados. A parte legal da estela $^{*}$ de Hammurabi estrutura-se em 282 parágrafos. Dentre esses, destacam-se os parágrafos 215 a 240 que regulam os direitos e obrigações de algumas classes de profissionais.

Bouzon (1998) comentou em sua obra, os diversos parágrafos legais do Código de Hammurabi limitando-se, essencialmente, a explicações filológicas e gramaticais, tentando esclarecer costumes e instituições da época.

Transcrevendo o parágrafo 218 do Código de Hammurabi, lê-se:

"Se um médico fez em um homem livre uma operação difícil com um escapelo de bronze e causou a morte do mesmo ou abriu o arco acima da sobrancelha de um homem livre com um escapelo de bronze e destruiu o olho, eles cortarão a sua mão".

\footnotetext{
* O texto de leis babilônicas foi conservado, em sua quase totalidade, na célebre estela de diorito negro, com 2,25 m de altura, que se encontra, hoje, no Museu do Louvre, em Paris. Não se trata do corpo de leis mais antigo da Baixa-Mesopotâmia, mas ele é, sem dúvida alguma, o mais extenso, o mais conhecido e, provavelmente, o mais importante. A autoria das leis é atribuída a Hammurabi, fundador da primeira dinastia babilônica, que reinou, conforme a cronologia média, entre os anos 1792-1750 aC. Hoje se discute muito sobre a natureza e a validade das leis reunidas nos corpos legais do Oriente Antigo.
} 
Em seu comentário a respeito do parágrafo 218 do Código de Hammurabi, Bouzon, op. cit., escreveu:

“É, sem dúvida, uma forma de aplicação do ius talionis, já que a mão do médico é, aqui, considerada o órgão agressor. Mas esta era, certamente, também uma maneira drástica de evitar futuras intervenções desastrosas desse médico" (Bouzon, 1998, p.189).

A idéia dominante de se punir o mal com o mal era, portanto, comum naquela época, a qual caracterizou uma evolução no que diz respeito à vingança coletiva nas sociedades antigas para a vingança privada na sociedade babilônica.

Diniz (1990) abordou a vingança privada, em que os homens faziam justiça pelas próprias mãos, sob a égide da Lei de Talião, sintetizada nas fórmulas: 'olho por olho, dente por dente'; 'quem com ferro fere, com ferro será ferido'. Na Lei das XII Tábuas, aparece significativa expressão desse critério na tábua VII, lei 11aㅗ si membrum rupsit, ni cum eo pacit, talio esto (se alguém fere a outrem, que sofra a pena de Talião, salvo se existiu acordo). Ressaltou Diniz que a responsabilidade era objetiva, não dependendo da culpa, apresentando-se apenas como uma reação do lesado contra a causa aparente do dano.

Comentou Prux (1998) que, naquela fase, o Poder Público apenas comparecia para declarar quando e como a vítima poderia vingar-se. Não se cogitava a reparação do dano, mas sim a concessão de direito à reação 
humana que, embora naturalmente violenta, recebia do Estado a devida guarida.

Seguinte àquela fase, vem a da composição entre o autor e o lesado, quando se aplica a 'poena', que seria o pagamento de certa quantia em dinheiro; a critério da autoridade pública, se o delito fosse público, e do lesado, se se tratasse de delito privado; do que cobrar a retaliação, porque esta não reparava dano algum, ocasionando na verdade duplo dano: o da vítima e o de seu ofensor, depois de punido. Na composição, abandonaramse agressivos instintos do homem primitivo (Séllos, 1994; Diniz, 1990; Prux, 1998).

Prosseguindo nessa seqüência evolutiva, a sociedade inclinou-se para a composição tarifada, imposta pela Lei das XII tábuas que, para certos casos, fixava a pena a ser paga pelo ofensor. Era ainda a fase da responsabilização estabelecida diretamente em casos concretos (Prux, 1998).

Foi somente com a Lex Aquilia de damno que a idéia de reparação pecuniária do dano firmou-se definitivamente. Impunha a mesma que o patrimônio do lesante suportasse os ônus da reparação, esboçando-se a noção de culpa como fundamento da responsabilidade, de tal sorte que o agente se isentaria de qualquer responsabilidade se tivesse agido sem culpa. Segundo Diniz (1990), passou-se a atribuir o dano à conduta culposa do agente. Escreveu a autora:

“A 'Lex Aquilia de damno' estabeleceu as bases da responsabilidade extracontratual, criando uma forma pecuniária de 
indenização do prejuízo, com base no estabelecimento de seu valor. Esta lei introduziu o 'damnum iniuria datum', ou melhor, prejuízo causado a bem alheio, empobrecendo o lesado, sem enriquecer o lesante. Todavia, mais tarde, as sanções dessa lei foram aplicadas aos danos causados por omissão ou verificados sem o estrago físico e material da coisa. O Estado passou, então, a intervir nos conflitos privados, fixando o valor dos prejuízos, obrigando a vítima a aceitar a composição, renunciando à vingança. Essa composição permaneceu no direito romano com o caráter de pena privada e como reparação, visto que não havia nítida distinção entre a responsabilidade civil e a pena" ( Diniz, 1990, p.10).

$\mathrm{Na}$ Idade Média, com a estruturação da idéia de dolo e de culpa, distinguiu-se a responsabilidade civil da penal.

Salientou Kfouri Neto (1996) que na Lex Aquilia encontram-se os primeiros rudimentos de responsabilidade médica, prevendo a pena de morte ou deportação do médico culpado de falta profissional.

Comentou o autor:

"De início, a medicina em Roma era praticada por curandeiros e sacerdotes, estes últimos depositários da prática curativa. (...) Com o tempo, a arte de curar passou a ser mais considerada e, na transição da Roma Republicana para a Roma Imperial, assiste-se a uma elevação cultural, jurídica e sanitária da medicina - que alcançou-se à dignidade de profissão, organizando-se cursos e sendo codificado um sistema para a proteção da saúde pública e higiene 
social. Iniciou-se, também, a especialização médica, surgindo os primeiros clínicos gerais e, até, oculistas" (Kfouri Neto, 1996, p.33).

Foram séculos de evolução. Porém, a teoria da responsabilidade civil só se estabeleceu por obra da doutrina, cuja figura dominante foi o jurista francês Domat, responsável pelo princípio geral da responsabilidade civil (Diniz, 1990). Mostrava-se, em sua substância, a doutrina da culpa fundada sempre no pressuposto de prévia existência de dolo, imprudência, imperícia ou negligência por parte do ofensor (Prux, 1998).

Concluiu Prux, op. cit., p.71:

"Pode-se dizer que, daí então, até o século atual, as formulações teóricas e práticas dessa área do direito, sobretudo o ocidental, giraram, basicamente, em torno da noção de culpa como o fator primordial para a existência de qualquer reparação civil'.

Já se reconhecia que a culpa poderia vir de descumprimento de um dever contratual ou não; surgir de uma ação ou mesmo de omissão; provir de um delito ou não. Os estudos evoluíram nessa fase para a formação das diversas modalidades de culpa (in vigilando, in eligendo, in comitendo), formando o universo dessa importante teoria.

Com a virada do século passado para o atual, com os problemas surgidos frente à nova realidade que se instaurou, a teoria da culpa já não resolvia satisfatoriamente as diversas situações que se apresentavam. Várias fórmulas foram tentadas para a busca de solução aos problemas atinentes à responsabilidade civil. O surgimento e a aceitação gradual da teoria do risco têm sua importância medida pelas milhares de situações que 
ela protege na vida moderna. Aos poucos, a doutrina foi, em certos casos, se afastando da responsabilidade dita subjetiva, aquela fundada unicamente na culpa, para aproximar-se da teoria objetiva.

Comentou Motta (1999):

"Com o surgimento das atividades perigosas, máxime após a revolução industrial, e com o transporte em massa de passageiros, foi criada a teoria da responsabilidade objetiva ou sem culpa. Em muitas hipóteses, o risco foi socializado" (Motta, 1999, p.74).

O Século XX trouxe, então, a consolidação da teoria do risco como forma aceitável e, em alguns casos, absolutamente necessária apara regular certas situações surgidas do tipo de vida social que a humanidade adotou. A prática veio, primeiramente, firmar a idéia da necessidade de reparação do dano, e, posteriormente, alentar novamente o antigo princípio de que quem aufere o ganho tem de assumir o risco (Prux, 1998).

Sintetizou Kfouri Neto (1996):

"Na responsabilidade objetiva, presume-se a culpa, por isso transfere-se ao causador o ônus de provar que não agiu culposamente, visando eximir-se da obrigação de indenizar. (...) $A$ exacerbação da responsabilidade objetiva conduz à teoria do risco. Nesta, havendo dano e nexo causal, seu autor somente se eximirá da obrigação de indenizar mediante prova de culpa exclusiva da vítima, caso fortuito ou força maior" (Kfouri Neto, 1996, p.48).

Oliveira (1999) abordou a teoria da responsabilidade objetiva e suas duas modalidades principais: a) a teoria do risco-proveito ou do dano 
objetivo, chamada ainda de teoria da culpa ex re ipsa; b) a teoria do risco criado ou do risco profissional. Considerou essa última como sendo mais abrangente, já que compreende todos os fatos prejudiciais decorrentes de uma atividade exercida em proveito próprio. Segundo esse entendimento, pelo simples fato de agir, o homem causa risco aos demais e por isso deve responder em caso de dano.

À luz do ordenamento jurídico pátrio, Séllos (1994) comentou que o Código de Defesa do Consumidor (CDC) vem regrar a matéria da responsabilidade de maneira inovadora, tendo por fundamento a teoria do risco da atividade, na qual o lesado não precisa demonstrar sequer a relação causal, bastando a existência de um dano para que se responsabilize o lesante. Fundado na teoria citada, o Código de Defesa do Consumidor tem como regra geral a inovadora teoria da responsabilidade objetiva, onde o lesado não tem que comprovar culpa do lesante, apenas a existência de um fato, dano e seu nexo de causalidade.

Bertoldi (1994) temporizou que o Constituinte de 1988 elegeu a defesa do consumidor ${ }^{*}$ como direito e garantia fundamental, bem como princípio da ordem econômica, demonstrando sensibilidade ao fenômeno da massificação das relações de consumo que, invariavelmente, geram graves distorções se não normatizadas de forma a proteger a parte mais vulnerável da relação de consumo, que é o consumidor.

* Artigo 5, inciso XXXII e Artigo 170, inciso V da CF. 
Ao analisar o quadro da responsabilidade civil até então em vigor em nosso País, constatou o autor que o legislador caminhou a passos largos para possibilitar o surgimento de relações de consumo equilibradas, de forma a ensejar o fortalecimento do mercado de consumo e a beneficiar a competência e honestidade nas relações de consumo (grifo nosso).

Ao colocar-se como de ordem pública, o Código de Defesa do Consumidor deu recado claro de que o princípio da autonomia da vontade não pode subsistir absoluto quando o interesse social é afetado (Art. $1^{\circ}$ do $\mathrm{CDC})$.

Destarte, os incisos I a VI do art. $4^{\circ}$ do CDC estabelecem princípios com o objetivo de atender às necessidades dos consumidores, o respeito à sua dignidade, saúde e segurança, a proteção de seus interesses econômicos, a melhoria da sua qualidade de vida, bem como a transparência e harmonia das relações de consumo.

0 art. $6^{0}$ do mesmo diploma legal estabelece os Direitos Básicos do Consumidor. Dentre outros, é direito básico do consumidor, para facilitar a defesa de seus direitos, poder o juiz inverter o ônus da prova no processo civil.

Nogueira (1994) enfatizou que o CDC - Lei no 8.078, de 11 de setembro de 1990, veio atender aos reclamos da sociedade e restabelecer o princípio da boa fé e da igualdade nas relações entre consumidores e fornecedores. Enfocando o ônus da prova nas relações de consumo a partir do CDC, alertou: 
"Deve ser ressaltado que o consumidor não está obrigado a provar que tomou todas as medidas preventivas necessárias para evitar um defeito ou um acidente, deve-se exigir do consumidor o que o comum dos homens leigos faria" (Nogueira, 1994, p. 59).

No art. 14 do CDC, parágrafo $4^{\circ}$, cuidou o legislador da reparação, pelos profissionais liberais, pelos danos decorrentes de seus serviços, sendo aberta exceção à teoria da responsabilidade objetiva, adotada pelo CDC.

Séllos (1994) mencionou o art. 14, parágrafo 4ํ do Código de Defesa do Consumidor como única exceção ao princípio da responsabilidade objetiva onde a responsabilidade pessoal do profissional liberal é baseada na culpa, ou seja, a responsabilidade é subjetiva. Assim, cabe ao lesado comprovar a ação ou omissão que desencadeou o dano, através da inobservância de um dever legal ou contratual, por negligência, imprudência ou imperícia por parte do profissional liberal ao desempenhar suas atividades.

Para melhor entendimento do conceito 'profissional liberal', Prux (1998) utilizou-se da conceituação presente no Pequeno Dicionário Brasileiro da Língua Portuguesa, de Aurélio Buarque de Hollanda Ferreira: "Profissão liberal. Profissão de nível superior caracterizada pela inexistência de qualquer vinculação hierárquica e pelo exercício predominantemente técnico e intelectual de conhecimentos". Concluiu o autor serem os profissionais liberais uma categoria de pessoas que, no exercício de suas atividades laborais, é perfeitamente diferenciada pelos conhecimentos 
técnicos reconhecidos em diploma de nível superior, não se confundindo com a figura do autônomo.

Com extrema competência e talento, Prux, opus citatum, explanou: " $A$ atividade dos profissionais liberais enquanto fornecedores não está contida apenas em um diploma legal. Dada a gama de formas de atuação e situações em que eles se envolvem no exercício de suas tarefas profissionais, sua conduta é disciplinada por diversas normas legais". Tradicionalmente essa conduta era regulamentada pelo Código Civil, mas de 1988 para frente, com a aprovação da mais recente Constituição pátria e do CDC, houve marcantes modificações nessa área. Esclareceu Prux que, respeitando o critério da hierarquia, recenticidade temporal e especificidade, e o fato de que o CDC não revogou por inteiro o contido no CCB quanto aos contratos dos profissionais, não há dúvida de que esse tipo de atividade principia a ser regulada em caráter geral, pelo contido na nossa Carta Magna, mas tem sua regulamentação fundamental no diploma legal específico, que é o CDC.

Coelho (1994) recordou que há uma categoria de prestadores de serviços que se encontra sujeita à disciplina específica no tocante aos defeitos de fornecimento. Trata-se dos profissionais liberais, que respondem apenas pelos danos decorrentes de conduta culposa (art. 14, $\S 4^{\circ}$ do CDC).

Denari (1998) comentou que 0 § $4^{\circ}$ (art. 14 do CDC) abre uma exceção ao princípio da objetivação da responsabilidade civil por danos:

"Trata-se do fornecimento de serviços por profissionais liberais cuja responsabilidade será apurada mediante verificação de culpa. 
Explica-se a diversidade de tratamento em razão da natureza 'intuitu personae' dos serviços prestados por profissionais liberais. De fato, os médicos e advogados - para citarmos alguns dos mais conhecidos profissionais - são contratados ou constituídos com base na confiança que inspiram aos respectivos clientes.

Assim sendo, somente serão responsabilizados por danos quando ficar demonstrada a ocorrência de culpa subjetiva, em quaisquer de suas modalidades: negligência, imprudência ou imperícia" (Denari, 1998, p.160).

Escreveu Oliveira (1999) que alguns doutrinadores, tomando por base o disposto no parágrafo $4^{\circ}$, art. 14 do CDC, passaram a compreender a responsabilidade dos profissionais liberais como de ordem estritamente subjetiva e impossível de ser dissociada da culpa profissional. O autor comentou não ser este o melhor entendimento.

Farah \& Ferraro (2000), ao abordarem Responsabilidade Civil e o Código de Defesa do Consumidor, comentaram que a responsabilidade objetiva facilita a atuação do advogado de um paciente interessado em obter uma indenização. A responsabilidade objetiva gera uma obrigação de resultado. No que tange à Responsabilidade Odontológica, escreveram:

"Grande parte de nossos juristas entende que, ao contrário dos procedimentos do campo da Medicina, numa grande parte dos tratamentos odontológicos é possível a previsão de um resultado. Dessa forma, tais tratamentos são em regra, obrigações de resultados, tendo o dentista, além dos deveres de empregar todo zelo 
necessário ao exercício de seu ofício e de se utilizar dos recursos de sua profissão, também a obrigação de garantir o fim esperado pelo paciente" (Farah \& Ferraro, 2000, p.48). 


\section{PROPOSIÇÃO}

Este trabalho científico tem o propósito de:

1. Investigar quais as condutas que os cirurgiões dentistas, especialistas em Ortodontia, vêm adotando no pós-tratamento ortodôntico.

2. Analisar, sob a ótica da Responsabilidade Civil Odontológica, as condutas adotadas pelos profissionais no pós-tratamento ortodôntico.

3. Interpretar, perante o Código de Defesa do Consumidor, se as condutas adotadas pelos profissionais da Ciência e Arte de Angle satisfazem normativas de um padrão no relacionamento paciente/profissional.

4. Relatar as condutas que os cirurgiões dentistas, especialistas em Ortodontia, vêm adotando após reclames de pacientes que já terminaram o tratamento corretivo. 


\section{MATERIAL E MÉTODOS}

\subsection{Material}

Para a realização deste trabalho, foi elaborado um protocolo* (Apêndice 1) em forma de questionário (Apêndice 2) contendo vinte e uma questões fechadas, distribuídas em três tópicos específicos:

I - Da Documentação Profissional = quatro questões,

II - Da Responsabilidade Profissional = oito questões,

III - Do Pós-Tratamento Ortodôntico = nove questões.

Foram disponibilizadas, no corpo inicial do questionário, linhas para informações pessoais do(a) entrevistado(a) e que, de forma espontânea, poderiam ou não ser declinadas. Instrução específica constou no ofício de apresentação da pesquisa (Apêndice 3), enviado junto com o questionário. 
4.2.1 A amostra

A população alvo é, muitas vezes, grande demais para ser usada integralmente. Para a realização deste trabalho, foi escolhida uma amostra da população alvo, também chamada de população estudada. Tentando reproduzir o mais fielmente possível a população alvo e, levando em conta suas características conhecidas, define-se a amostra deste trabalho como sendo do tipo não probabilística (Contandriopoulos et al., 1997).

Foram selecionados, por escolha racional, cirurgiões dentistas inscritos no Conselho Regional de Odontologia do Paraná, com seus registros no Conselho Federal de Odontologia como especialistas em Ortodontia.

Os questionários foram encaminhados aos componentes da amostra em forma de carta resposta, via correio. As informações presentes no Catálogo Nacional de Ortodontia - 1999/2000, da Associação Brasileira de Ortodontia $(\mathrm{ABOR})$, foram utilizadas para tal desiderato. O referido catálogo foi disponibilizado nacionalmente via correio, aos mencionados profissionais cirurgiões dentistas.

$\mathrm{Na}$ organização desse catálogo, elaborado por Estado, foram relacionados 233 (duzentos e trinta e três) cirurgiões dentistas especialistas em Ortodontia, inscritos no Conselho Regional do Paraná.

\subsubsection{Tamanho da amostra}


Quando escolhemos uma amostra, é essencial determinar seu tamanho. Para isto, podem ser levados em conta dois tipos de critérios: os critérios de ordem prática e os critérios de ordem estatística. Considerando a amostra não probabilística deste trabalho e que os métodos estatísticos utilizados para determinar seu tamanho não são pertinentes, optou-se pelo critério prático.

Num universo de 232 (duzentos e trinta e duas) correspondências expedidas, retornaram 101 (cento e uma), assim distribuídas:

- 95 (noventa e cinco) correspondências retornaram com os questionários respondidos ( $40,9 \%$ do total enviado);

- 05 (cinco) correspondências retornaram ao remetente sem respostas ao questionário devido à mudança de endereço dos destinatários $(2,1 \%$ do total enviado);

- 01 (um) correspondência retornou ao remetente sem respostas ao questionário devido ao endereço do destinatário ser desconhecido ( $0,4 \%$ do total enviado).

A estratégia adotada visou, então, maximizar a utilidade das informações presentes nos questionários respondidos.

4.2.3 Análise dos dados 
Adotou-se o estudo quantitativo na análise dos dados.

Utilizando os recursos da informática, os dados coletados foram digitados em quatro planilhas elaboradas com o auxílio do programa Excel e seu Assistente Gráfico, presentes no "software" Microsoft® Windows® ${ }^{\circledR}$ 98*. O "hardware" empregado foi o modelo InfoWay**, número de série 9828801600070, com processador Pentium II 400MHz, HD 4.3 Gb UDMA2, placa de vídeo $8 \mathrm{Mb}$ AGP com acelerador 3D (100 MHz), 64Mb de memória DIMM/SDRAM (ECC) e monitor multimídia-digital de 15 polegadas.

Os dados receberam tratamento estatístico de forma descritiva e inferencial. $\mathrm{Na}$ análise descritiva utilizaram-se figuras (diagramas em barras e setores) e tabelas na representação dos achados. Na análise inferencial usaram-se porcentagens numéricas de ocorrência dos fenômenos colhidos.

\footnotetext{
* InfoWay Master CD.

** Itautec Philco S.A. - Grupo Itautec Philco. São Paulo, 1998.
} 


\section{RESULTADOS}

Os resultados do presente trabalho foram obtidos através do retorno de noventa e cinco questionários e serão expressos em quatro blocos, levando-se em consideração a seqüência empregada no questionário utilizado: 5.1 Do profissional; $5.2 \mathrm{Da}$ documentação profissional; $5.3 \mathrm{Da}$ responsabilidade profissional e; 5.4 Do pós-tratamento ortodôntico.

\subsection{Do profissional}

Computaram-se correspondências de vinte e oito municípios do Estado do Paraná.

A distribuição da amostra por município foi caracterizada através da postagem. Observou-se em cada carta-resposta o nome do município donde o profissional estava enviando.

A distribuição das cartas-resposta por município foi representada na Tabela 5.1 
TABELA 5.1 - Número de cartas-resposta recebidas por município

\begin{tabular}{|c|c|}
\hline MUNICÍPIO & NÚMERO DE CARTAS-RESPOSTA \\
\hline Curitiba & 38 \\
\hline Londrina & 13 \\
\hline Ponta Grossa & 8 \\
\hline Maringá & 4 \\
\hline Cascavel & 3 \\
\hline Umuarama & 3 \\
\hline Foz do Iguaçú & 2 \\
\hline Guarapuava & 2 \\
\hline Santo Antonio da Platina & 2 \\
\hline Toledo & 2 \\
\hline Apucarana & 1 \\
\hline Arapongas & 1 \\
\hline Assai & 1 \\
\hline Campo Mourão & 1 \\
\hline Cianorte & 1 \\
\hline Colorado & 1 \\
\hline Cornélio Procópio & 1 \\
\hline Francisco Beltrão & 1 \\
\hline Guairá & 1 \\
\hline Ibaiti & 1 \\
\hline Irati & 1 \\
\hline Jacarezinho & 1 \\
\hline Loanda & 1 \\
\hline Manoel Ribas & 1 \\
\hline Paranavaí & 1 \\
\hline Rolândia & 1 \\
\hline São José dos Pinhais & 1 \\
\hline Wenceslau Braz & 1 \\
\hline TOTAL & 95 \\
\hline
\end{tabular}

No que se refere à distribuição de cartas resposta por municípios, constatou-se que os seis primeiros representaram $72,6 \%$ do total da amostra. 
A distribuição da amostra pelo sexo ficou composta por 65 profissionais do sexo masculino (69\%), 27 profissionais do sexo feminino (28\%) e 3 não declarados (3\%).

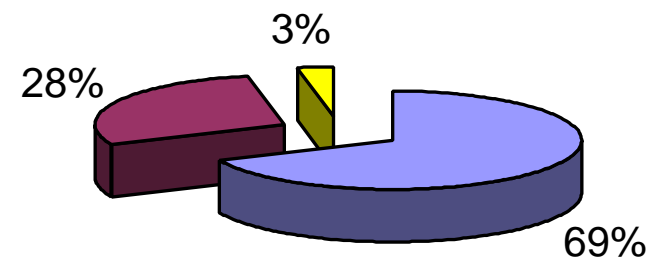

$\square$ masculino $\square$ feminino $\square$ não declarados

Figura 1 - Distribuição pelo sexo

No que respeita à distribuição por idade, os profissionais foram distribuídos por faixas etárias (Figura 2), definidas com intervalos de idade variando dos 30 aos 39 anos (52 profissionais), dos 40 aos 49 anos (27 profissionais), dos 50 aos 59 anos (9 profissionais), dos 60 aos 69 anos (3 profissionais). Computaram-se mais quatro profissionais que não declararam a idade.

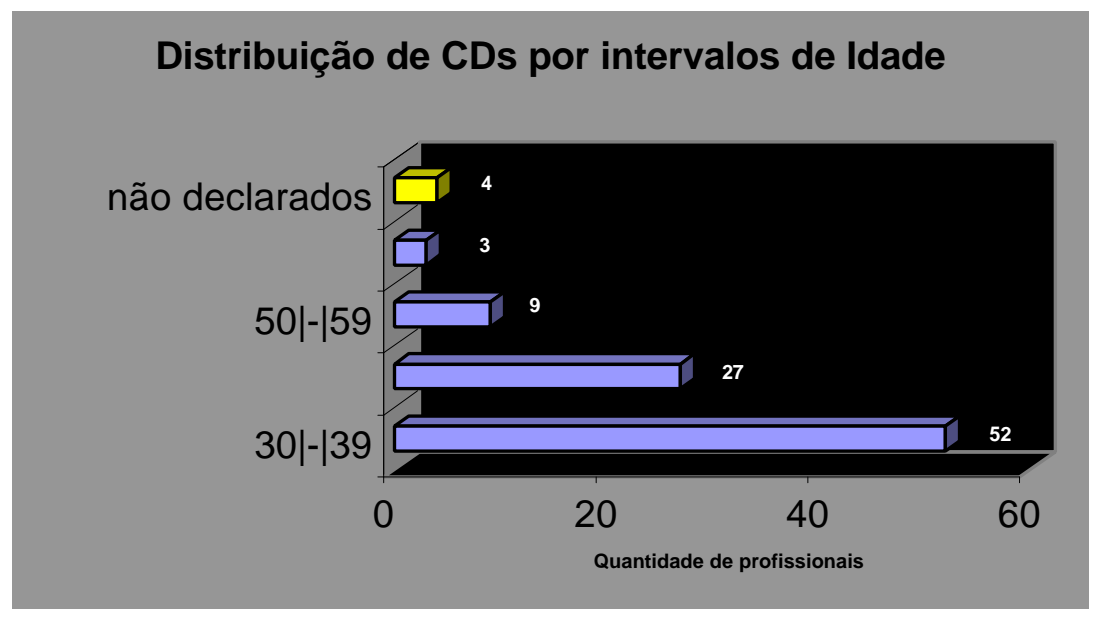

Figura 2 - Distribuição por idade 
Nos dois primeiros intervalos, 30|-|39 e 40|-|49 anos, concentrou-se a grande maioria de profissionais com $54,7 \%$ e $28,4 \%$, respectivamente. Os mesmos representaram $83,1 \%$ do total da amostra.

A Figura seguinte mostra a distribuição dos profissionais de acordo com a formação de pós-graduação: lato sensu (especialista); stricto sensu (mestrado e doutorado).

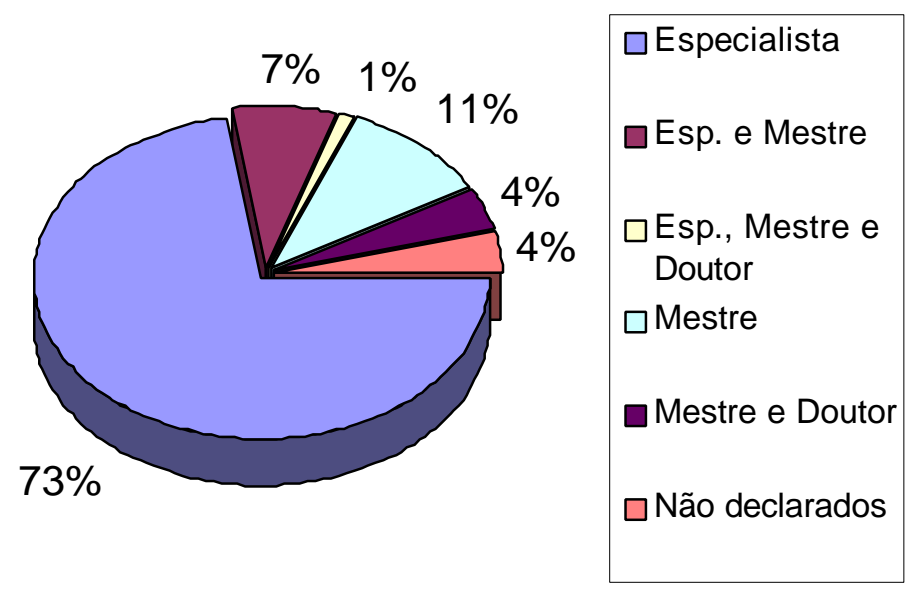

Figura 3 - Formação acadêmica

As respostas foram agrupadas considerando-se cinco categorias: especialista, que compreende a maioria da amostra (73\%); especialista e mestre (7\%); especialista, mestre e doutor (1\%); mestre $(11 \%)$; mestre e doutor (4\%). Observou-se um predomínio da formação lato sensu (73\%) sobre a formação stricto sensu (23\%). No universo dos profissionais doutores, um cursou pós-graduação em Odontologia, área de concentração em Ortodontia, em níveis de mestrado e doutorado na Universidade do Estado de São Paulo; outro cursou pós-graduação em Odontologia, área de concentração em Ortodontia, em nível de mestrado na Faculdade de Odontologia de Bauru e doutorado na Universidade do Estado de São 
Paulo. Os demais doutores (três) cursaram pós-graduação em Odontologia, área de concentração em Ortodontia, em níveis de mestrado e doutorado na Universidade Federal do Rio de Janeiro. Computaram-se 4\% de profissionais que não informaram sobre a temática.

\subsection{Da documentação profissional}

Observou-se conduta uniforme quanto à documentação inicial, já que todos os profissionais a solicitam antes de iniciarem um tratamento ortodôntico, conforme a Figura 4.

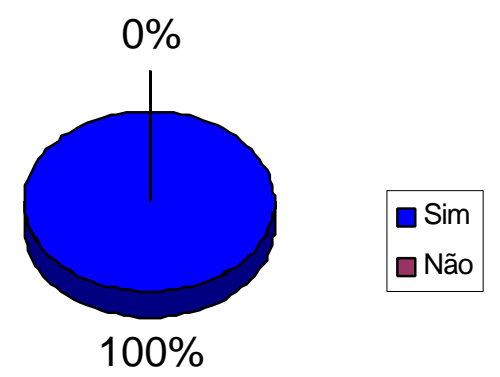

Figura 4 - Solicitação da documentação inicial

Coletando dados pertinentes ao desenvolvimento da temática, abordou-se também a solicitação da documentação ao término do tratamento ortodôntico: 79\% responderam solicitar documentação final; 16\% informaram não solicitar documentação ao término do tratamento ortodôntico; e houve $5 \%$ de respostas diferenciadas, informando que às vezes a documentação final é solicitada. 


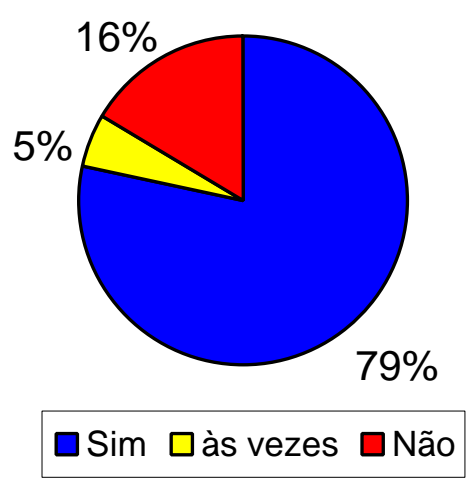

Figura 5 - Solicitação da documentação ao término do tratamento

Quanto ao arquivamento da documentação, 99\% das respostas foram 'sim'. Obteve-se uma resposta 'não', cujo profissional respondente declinou a seguinte informação: "não arquivo porque o paciente fica como fiel depositário, uma vez que assina documento comprobatório".

Conforme pode ser verificado na Figura $6,25 \%$ dos sujeitos da amostra afirmaram arquivar a documentação por cinco anos; a mesma porcentagem foi encontrada para o período de dez anos; 7\% informaram arquivar a documentação por quinze anos; $11 \%$ arquivam por vinte anos; e $32 \%$ arquivam a documentação por mais de vinte anos.
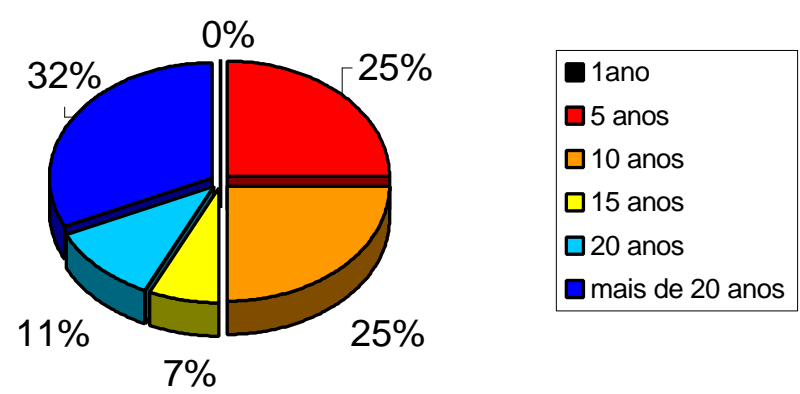

Figura 6 - Período de arquivamento da documentação

\subsection{Da responsabilidade profissional}


No capítulo da Responsabilidade Profissional iniciou-se argüindo a respeito do conhecimento dos prazos para reclames à Justiça, cujos resultados encontram-se na Figura abaixo.

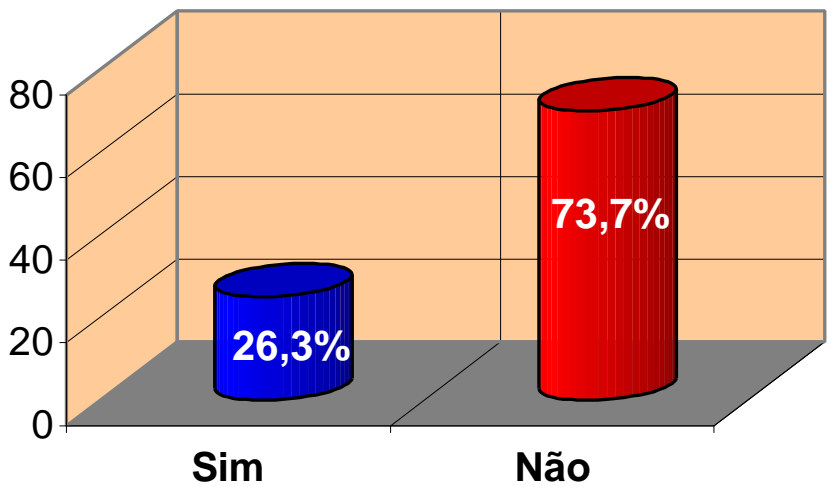

Figura 7 - Consciência plena da limitação do tempo para reclames à Justiça em relação ao tratamento odontológico

Observa-se que somente $26,3 \%$ responderam 'sim'; sendo que $73,7 \%$ dos profissionais 'não' estão conscientes do tempo prescricional que terá o paciente para reclames à Justiça em relação ao tratamento odontológico.

Abordando o conhecimento do Art. 177 do Código Civil Brasileiro (artigo que trata da prescrição aplicável às ações pessoais), a Figura 8 evidencia que $16,8 \%$ da amostra têm conhecimento sobre o referido. Os demais componentes da amostra (83,2\%) revelaram desconhecer esse artigo e seus aspectos relacionados ao Código Civil. 


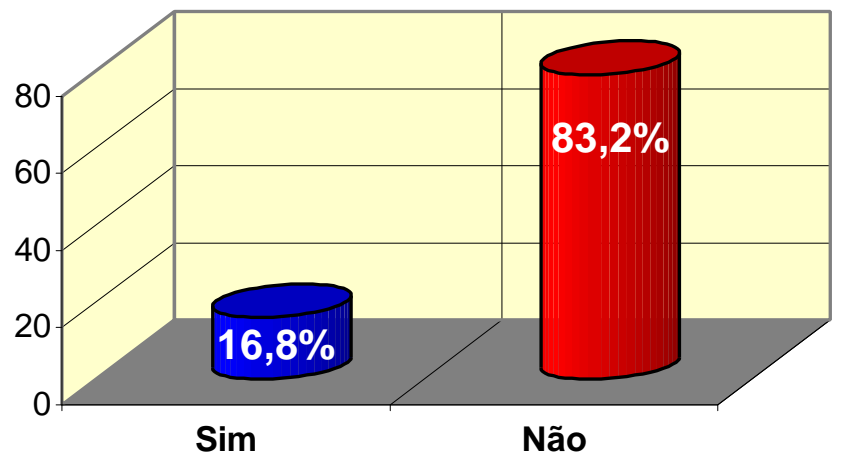

Figura 8 - Conhecimento do profissional a respeito do Art. 177 do CCB

Questionou-se sobre o conhecimento do termo técnico que estava sublinhado - as provas que porventura o cirurgião dentista apresente à Justiça são pré-constituídas: $77,9 \%$ dos profissionais responderam não conhecer o termo, $20 \%$ responderam conhecer o termo em questão e $2,1 \%$ não responderam (vide Figura 9).

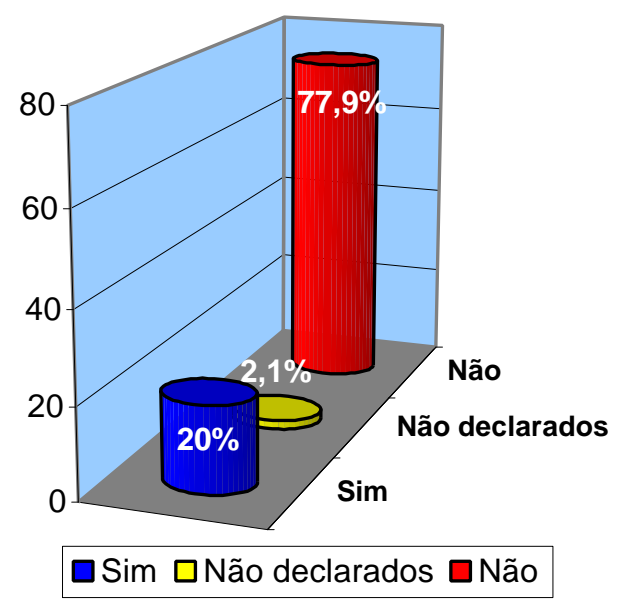

Figura 9 - Conhecimento do profissional no que diz respeito ao termo sublinhado: as provas que porventura o CD apresente à justiça são pré-constituídas 
Abordando a problemática da adoção de algum modelo ou forma de contrato pertinente ao tratamento ortodôntico que estaria em vias de ser instituído, 67\% responderam que adotam algum modelo ou forma de contrato; 32\% não adotam; e um profissional respondeu que às vezes adota algum modelo ou forma de contrato.

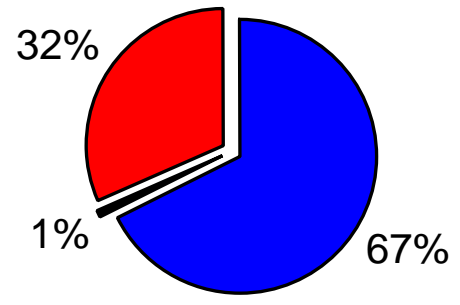

$\square$ Sim às vezes $\square$ Não

Figura 10 - Adotar algum modelo ou forma de contrato

Dos profissionais que adotam contrato, $48 \%$ informaram que fazem ressalvas no corpo do mesmo. Outros $45 \%$ não fazem ressalvas e $7 \%$ nada declararam (Figura 11).

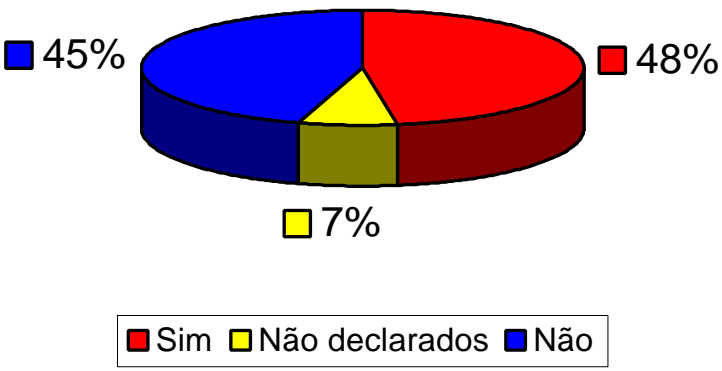

Figura 11 - Fazer ressalvas no corpo do contrato 
O gráfico a seguir mostra os resultados sobre o conhecimento da validade das ressalvas nos contratos: $59 \%$ dos profissionais responderam que não estão cientes da validade, 37\% responderam estarem cientes da validade de tais ressalvas e outros $4 \%$ não responderam essa questão.

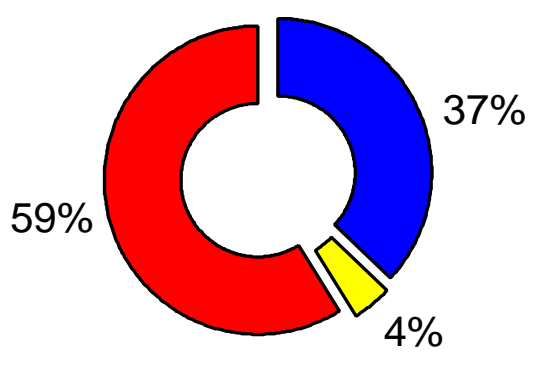

$\square$ Sim $\square$ Não declarados $\square$ Não

Figura 12 - Ciência da validade das ressalvas no contrato

Sobre ser "a natureza jurídica da responsabilidade profissional do cirurgião dentista como sendo de meio ou resultado", a figura abaixo evidencia que $60 \%$ dos especialistas em ortodontia a consideram de resultado e $29 \%$ de meio. Os demais profissionais não se manifestaram (11\%).

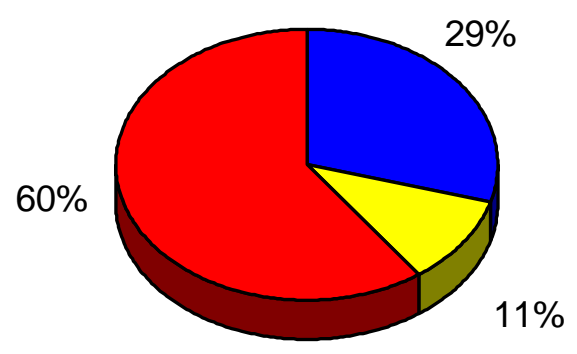

$\square$ Meio $\square$ Não declarados $\square$ Resultado

Figura 13 - Natureza jurídica da responsabilidade profissional 
Finalmente, na Figura 14 questionou-se qual/quais procedimento(s) ou conduta(s) é/são adotado(s) pelo cirurgião dentista quando o paciente solicita a retirada de documentos da clínica.

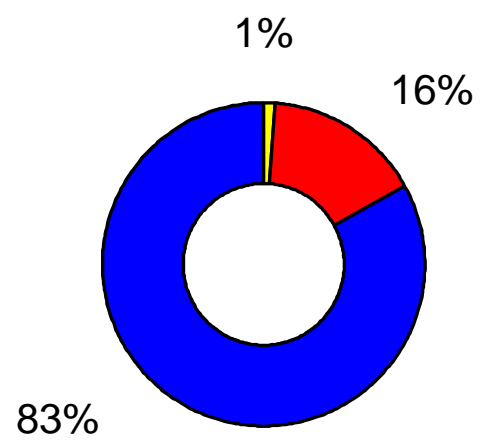

$\square$ Não entregar $\square$ Entregar $\square$ Entregar com ass. do termo

Figura 14 - Procedimento adotado pelo cirurgião dentista quando o paciente solicita a retirada de documentos

A grande maioria (83\%) respondeu que entregaria a documentação solicitando que o paciente assinasse um termo de retida da documentação; $16 \%$ responderam que entregariam a documentação e um profissional informou não entregar a documentação. 


\subsection{Do pós-tratamento ortodôntico}

A primeira pergunta referiu-se à adoção de aparelhos de contenção. Os resultados revelaram que $100 \%$ dos profissionais adotam como rotina aparelhos de contenção.

Questionou-se, em seguida, em que período o profissional recomenda o uso dos aparelhos de contenção (Figura 15).

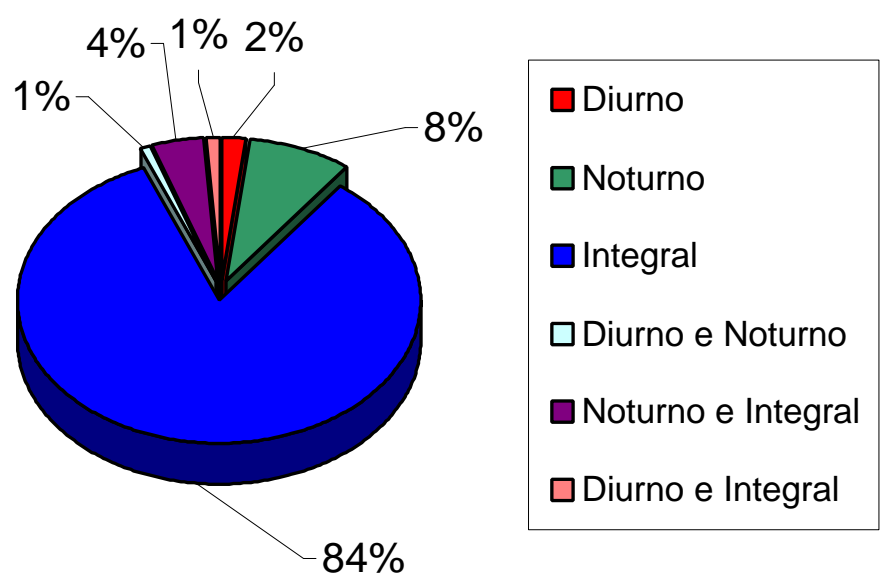

Figura 15 - Período recomendado de uso dos aparelhos de contenção

Dentre os períodos citados no questionário enviado aos profissionais, o período integral foi o mais recomendado (84\%). As outras opções de resposta receberam as porcentagens: período noturno (8\%) e diurno $(2 \%)$. Como alguns profissionais marcaram mais de um período, o gráfico acima apresentou outras três composições: noturno e integral (4\%); diurno e noturno (1\%); diurno e integral (1\%).

A Tabela 5.2 apresenta os resultados da seguinte questão: por quanto tempo o profissional recomenda o uso dos aparelhos de contenção. TABELA 5.2 - Tempo recomendado de uso dos aparelhos de contenção 


\begin{tabular}{c|c|c}
\hline ASPECTOS QUESTIONADOS & ABSOLUTO & $\%$ \\
\hline 6 meses & 09 & 08 \\
\hline 1 ano & 31 & 28 \\
\hline 1 ano e meio & 19 & 19 \\
\hline 2 anos & 20 & 02 \\
\hline 2 anos e meio & 02 & 03 \\
\hline 3 anos & 03 & 08 \\
\hline Até 5 anos & 09 & 14 \\
\hline Mais tempo & 15 & $\mathbf{1 0 0}$ \\
\hline TOTAL & $\mathbf{1 0 8}$ & \\
\hline
\end{tabular}

Observa-se a concentração dos resultados para os períodos de um ano (28\%), um ano e meio (18\%) e dois anos (19\%), totalizando $65 \%$ da amostra.

Quanto ao retentor inferior e utilizando-se os mesmos intervalos temporais, as repostas ao questionário estão apresentadas na Tabela 5.3

TABELA 5.3 - Distribuição das respostas referentes ao tempo que o profissional mantém o retentor inferior colado 


\begin{tabular}{c|c|c}
\hline ASPECTOS QUESTIONADOS & ABSOLUTO & $\%$ \\
\hline 6 meses & 00 & 00 \\
\hline 1 ano & 03 & 03 \\
\hline 1 ano e meio & 03 & 03 \\
\hline 2 anos & 10 & 01 \\
\hline 2 anos e meio & 01 & 13 \\
\hline 3 anos & 13 & 29 \\
\hline Até 5 anos & 30 & 41 \\
\hline Mais tempo & 43 & $\mathbf{1 0 0}$ \\
\hline TOTAL & $\mathbf{1 0 3}$ &
\end{tabular}

Porém, no que diz respeito à tabela 5.3, observa-se uma concentração dos resultados quanto ao tempo que o profissional mantém o retentor inferior colado. A soma das porcentagens obtidas nas respostas 'até 5 anos' e 'mais tempo' totalizou $70 \%$, contrariamente aos resultados obtidos para o item anterior.

Quanto às condutas adotadas nos casos de recidiva durante 0 período de contenção, na Figura 16 pode-se observar que 49\% dos profissionais optaram pelo retratamento ortodôntico. Seguem-se as demais opções: ajuste oclusal (24\%); reconstruções estéticas com auxílio da dentística (16\%); reconstruções estéticas com auxílio da prótese (3\%); reconstruções oclusais com auxílio da dentística (3\%); reconstruções oclusais com auxílio da prótese (3\%); cirurgia (2\%); e nenhum procedimento é adotado (0\%). 


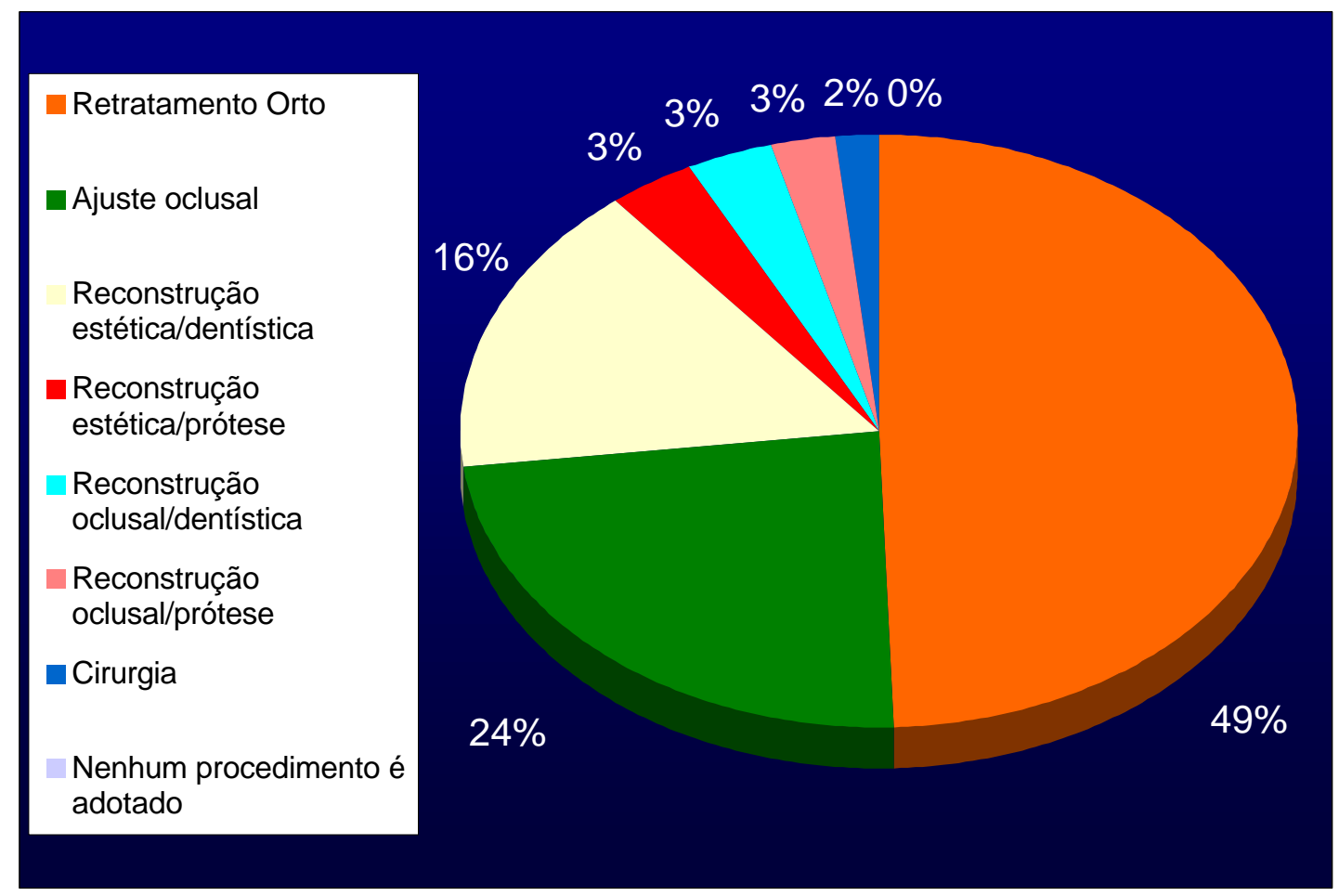

Figura 16 - Condutas adotadas nos casos de recidiva durante o período de contenção

Pesquisou-se também a conduta adotada pelo profissional nos casos de recidiva após o período de contenção. A Figura 17 demonstra que $70 \%$ dos profissionais informam ao paciente que é uma circunstância 'natural' e propõem o retratamento ortodôntico; 18\% responderam informar ao paciente que devido a circunstâncias atípicas ensejaram o retratamento ortodôntico, cobrando novos honorários profissionais; 4\% responderam informar somente que seria necessário retratar o caso clínico e cobrar novos honorários. Nas demais alternativas registraram-se as seguintes porcentagens: informar ao paciente que é uma circunstância natural (6\%); informar ao paciente que é uma circunstância natural e que nenhum 
procedimento clínico seria adotado (1\%); nada informar ao paciente e retratar o caso clínico (1\%); nada informar ao paciente e não retratar o caso clínico (0\%).

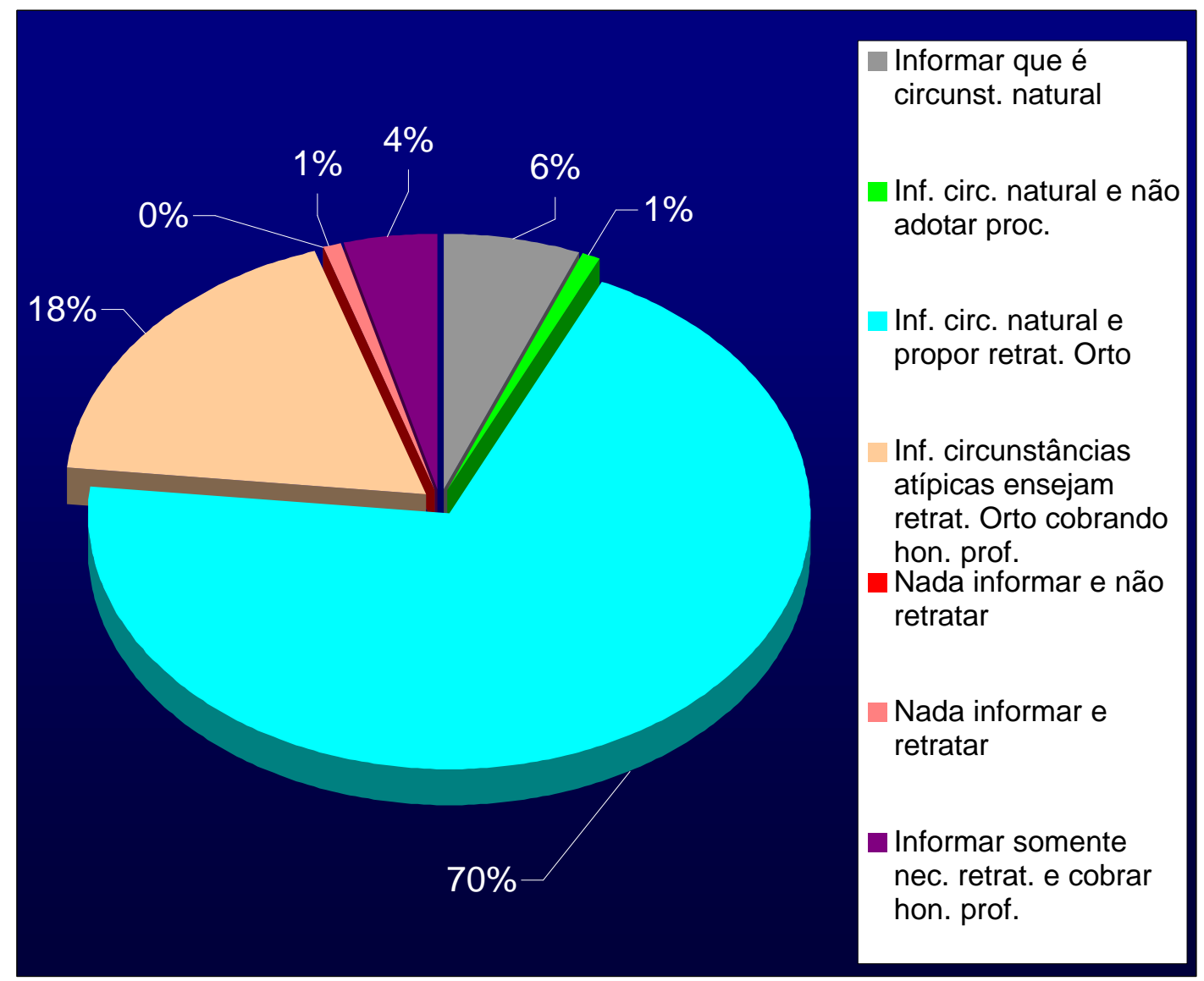

Figura 17 - Condutas adotadas nos casos de recidiva após o período de contenção

Sobre o controle que o profissional adota no período pós-contenção perguntou-se com que freqüência ele supervisiona seu paciente (Figura 18). 


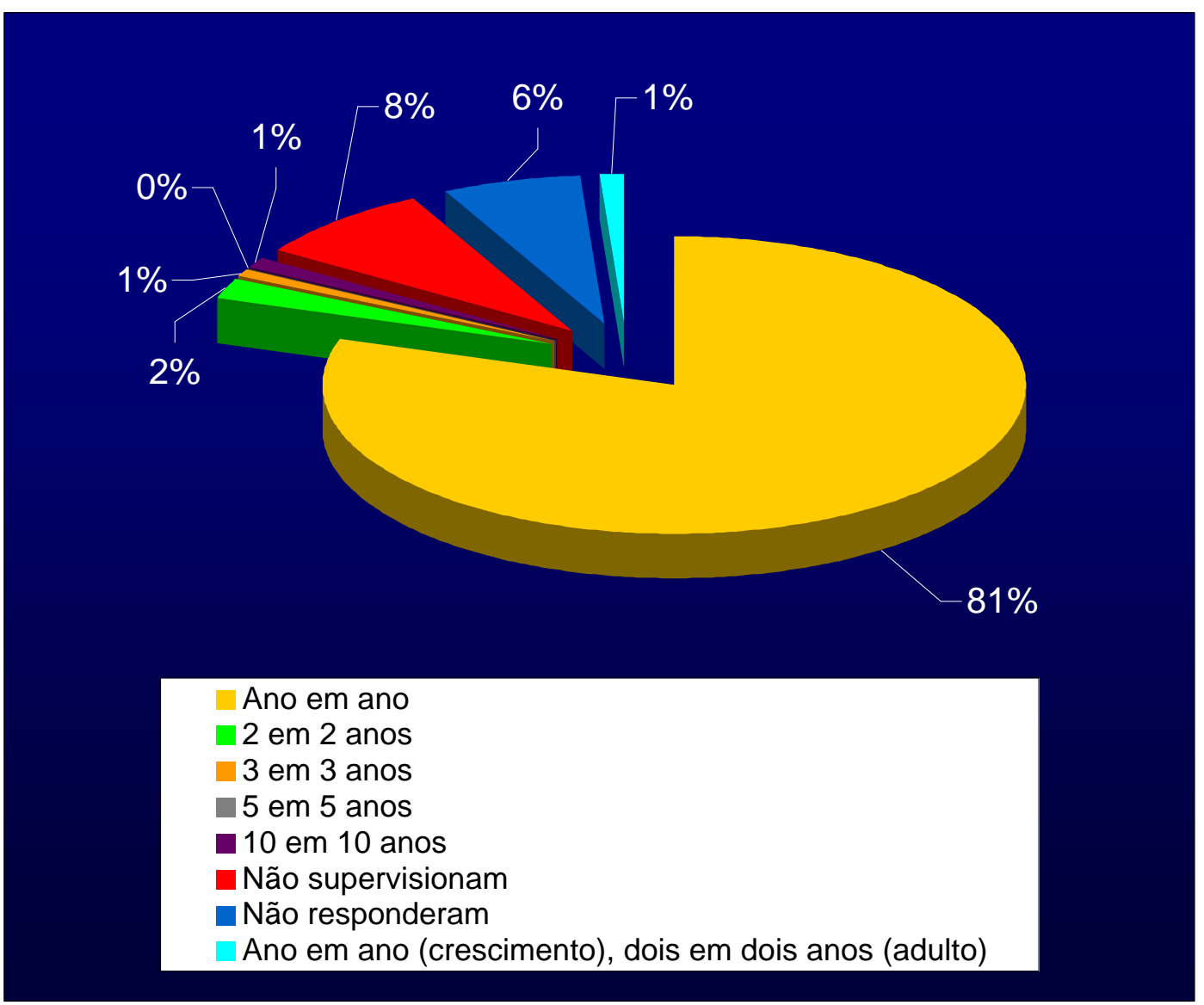

Figura 18 - Freqüência de supervisão no período pós-contenção

Do total da amostra, $81 \%$ dos profissionais supervisionam o paciente de ano em ano; $2 \%$ supervisionam de dois em dois anos; $1 \%$ supervisiona de três em três e dez em dez anos. A opção de supervisionar o paciente de cinco em cinco anos não foi assinalada (0\%), como expressa a Figura acima. Computaram-se ainda as seguintes respostas: não supervisionam o paciente (8\%); não responderam à questão (6\%); e supervisão anual do paciente em crescimento e de dois em dois anos o paciente adulto (1\%).

Quanto à conduta adotada pelo cirurgião dentista perante o paciente insatisfeito com os resultados do tratamento ortodôntico, das seis opções de resposta, duas se destacaram (Figura 19). 


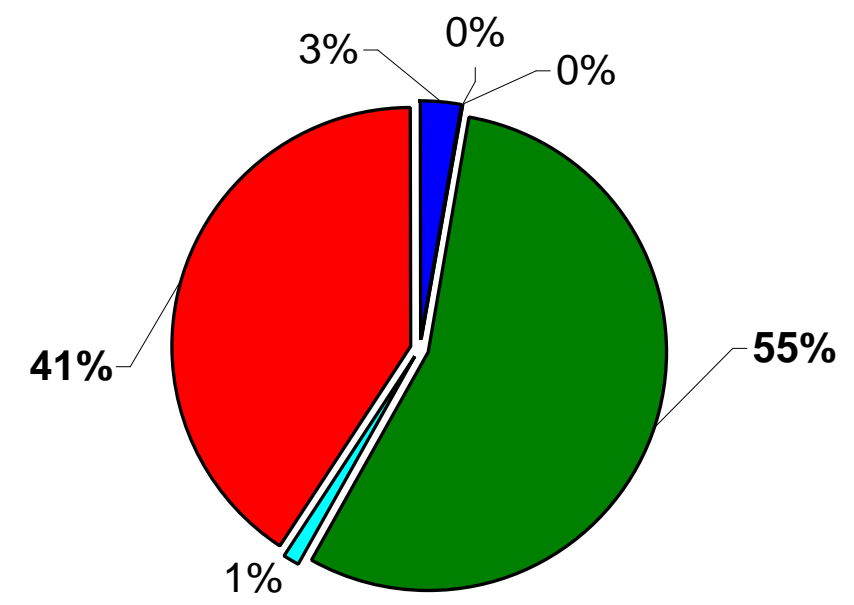

$\square$ Solicitaria procurasse outro profissional

$\square$ Desconsideraria relames do pac.

$\square$ Perante os reclames colocaria: Procure seus direitos!

$\square$ Procuraria, de qualquer forma, evitar que pac. agilizasse ação cível

$\square$ Comunicar fato ao Advogado e contratá-lo, pré-litigosamente

$\square$ Outra conduta

Figura 19 - Conduta adotada perante a insatisfação do paciente

O resultado, em ordem decrescente, foi o que se segue:

$55 \%$ procurariam, de qualquer forma, evitar que o paciente agilizasse ação de ordem cível;

$41 \%$ teriam outras condutas ${ }^{*}$ (disponibilizou-se espaço no questionário para o profissional especificar);

$3 \%$ solicitariam que o paciente procurasse outro profissional;

$1 \%$ comunicaria o fato ao seu advogado e o contrataria, mesmo que ainda numa condição pré-litigiosa.

Condutas mais citadas:

a) dialogaria com o paciente;

b) procuraria resolver o problema com o paciente;

c) procuraria identificar a (s) causa (s) da insatisfação;

d) tentaria um acordo com o paciente;

e) obteria opiniões com outros ortodontistas;

f) retrataria ortodonticamente sem cobrar novos honorários profissionais. 
Duas opções presentes no questionário não foram assinaladas: desconsideraria os reclames do paciente e, perante os reclames do paciente, Ihe retribuiria com a colocação 'procure seus direitos'.

A última pergunta do questionário diz respeito ao envolvimento do profissional numa ação de responsabilidade civil, impetrada por paciente, cujos resultados estão expressos na Figura 20. Pode-se observar que 4,2\% do total da amostra já estiveram envolvidos com lides processuais.

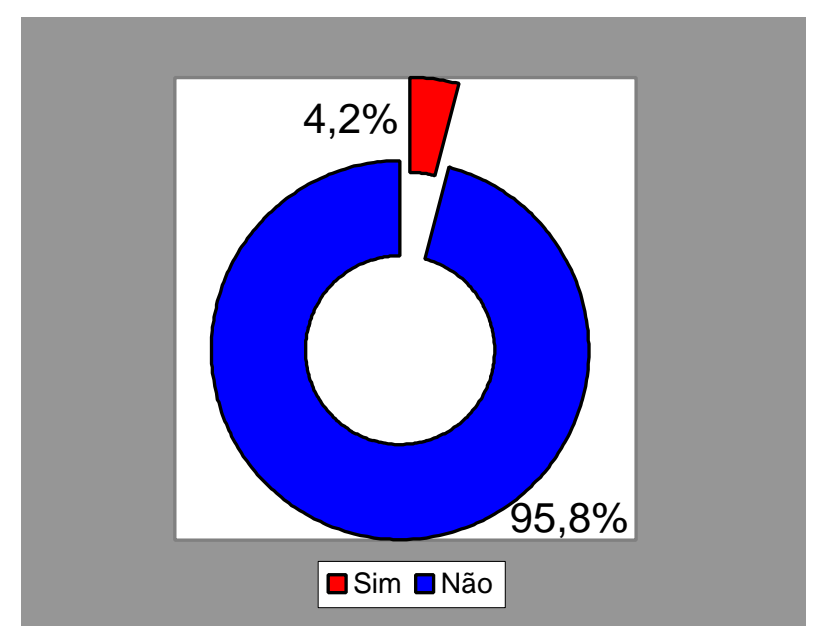

Figura 20 - CD envolvido numa ação de responsabilidade civil 


\section{DISCUSSÃO}

Um dos principais objetivos do tratamento ortodôntico é a estabilidade a longo prazo dos resultados obtidos. Alguns fatores responsáveis pela contenção e estabilidade não têm recebido a atenção tal qual outras áreas, como por exemplo: o diagnóstico, o plano de tratamento e a biomecânica (Nanda \& Burstone, 1994). Isso sem abordar as constantes evoluções da aparatologia e técnicas do tratamento ortodôntico.

Há um consenso na literatura sobre o fato de que não cabe apenas ao ortodontista tratar uma maloclusão (Hawley, 1919; Hellmann, 1945; Reitan, 1969; Reidel, 1969; Reidel, 1976; Proffit, 1986; Little \& Riedel, 1989; Baptista, 1993; Nanda \& Zernik, 1994; Alexander, 1994; Alexander, 1997; Blacke \& Bibby, 1998). A fase do pós-tratamento ortodôntico (contenção e pós-contenção) é tão importante quanto aquela que antecede o tratamento, bem como a do próprio tratamento ativo.

A despeito do reconhecimento de trabalhos que versam sobre contenção e estabilidade em ortodontia, a exigüidade de pesquisas relacionando o pós-tratamento ortodôntico com a responsabilidade civil do cirurgião dentista fragiliza uma discussão comparativa. 
Um primeiro aspecto a ser salientado, na presente Discussão, é o retorno das cartas-resposta. A literatura aponta para o fato da alta proporção dos que não respondem questionário através da postagem (Contandriopoulos et al., 1997). Recente reportagem na imprensa leiga*, de grande circulação nacional, publicou que o índice de respostas às mensagens por e-mail é muito maior (40\%) do que por correio normal $(0,5 \%)$

Comparando os dados desses trabalhos com os nossos, verifica-se que, com o retorno de 95 (noventa e cinco) correspondências com os questionários respondidos (40,9\% do total enviado), a ocorrência foi muito superior em nosso estudo. Em conformidade com nosso índice de respostas aos questionários, ousamos declinar a idéia de que os elementos típicos selecionados (os especialistas) maximizam a aplicabilidade dos resultados, já que demonstraram interesse pela temática exposta.

Quanto à distribuição regional das cartas-resposta, pode-se ressaltar que a maioria dos profissionais que enviaram as correspondências atuava, na época, nos municípios com maior concentração de população urbana do Estado do Paraná**.

Com base, portanto, nos questionários respondidos por esses profissionais, centraremos a presente Discussão nos resultados apresentados.

"VARGAS, N.; PETERSON, E. Não me mandem esse lixo! Rev Veja, a.33, n.38, p.130-132, set. 2000.

${ }^{\star *}$ Fonte Almanaque Abril 1999. 


\subsection{Do profissional}

Ainda que estivesse explicitada a não necessidade da identificação, um grande número de profissionais identificou-se espontaneamente.

A tabulação dos dados pessoais, obtidos nos questionários, caracterizou o perfil do profissional que compôs a amostra: ortodontista na faixa etária dos 30 aos 49 anos, predominância do sexo masculino, formação acadêmica em nível de especialista e clinicando nas cidades maiores.

$\mathrm{Na}$ formação acadêmica do profissional verificou-se uma variação acentuada no que diz respeito ao intervalo de tempo entre a conclusão do curso de graduação e da pós-graduação, indo de dois a vinte e sete anos. $\bigcirc$ universo amostral evidenciou o predomínio da formação lato sensu sobre a formação stricto sensu. A atual diversidade dos cursos de especialização (lato sensu) em ortodontia corrobora nossos achados.

\subsection{Da documentação profissional}

A literatura compulsada aponta para a importância da documentação no exercício da prática clínica médica e odontológica (Crosby \& Crosby, 1987; Machen, 1989; Machen, 1992; Cardozo, 1993; Louzã, 1995; Silva, 1997; Calvielli, 1997; Aguiari et al, 1998; Farah \& Ferraro, 2000).

No que se refere à solicitação da documentação inicial, podemos observar que os profissionais que compõem a nossa amostra reconhecem 
essa importância apontada pela literatura, já que 100\% solicitam documentação antes de iniciarem um tratamento ortodôntico.

Já os resultados apurados no segundo questionamento, solicitação da documentação ao término do tratamento ortodôntico, que foram confrontados com a literatura (Crosby \& Crosby, 1987; Machen, 1992; Cardozo, 1993; Silva, 1994; Louzã, 1995; Calvielli, 1997; Silva, 1997; Maciel, 1997; Teixeira Filho, 1999), permitem-nos afirmar que parte dos profissionais da nossa amostra poderá estar exposta a circunstâncias extremamente desfavoráveis. Nossa preocupação sedimenta-se nos resultados, haja vista que $16 \%$ dos profissionais responderam não solicitar e $5 \%$ informaram que às vezes solicitam documentação ao término do tratamento ortodôntico. Tais condutas poderão trazer sérias conseqüências para esses profissionais, pois a documentação profissional é de fundamental importância, tanto no aspecto do controle do paciente no póstratamento ortodôntico, bem como para respaldá-los perante uma possível lide jurídica (ação de responsabilidade civil).

Considerando o arquivamento da documentação, 99\% dos profissionais informaram arquivá-la. Interessou-nos sobremaneira a conduta adotada por um profissional, o qual escreveu no corpo do questionário que não arquiva a documentação. O seu argumento para tal atitude é o de que, ao findar a fase corretiva, entrega a documentação ao paciente, respaldando-se num documento comprobatório que elabora e o paciente assina. Dessa forma, o paciente torna-se fiel depositário. 
Cabe salientar que, embora o fato provavelmente não seja do conhecimento do mencionado profissional, essa conduta infringe o disposto na legislação em vigor. O próprio Código de Ética Odontológica em matéria específica dispõe (CFO-179, 1998):

"Dos Deveres Fundamentais:

Art. 4ํㅜㄴ item VI - elaborar as fichas clínicas dos pacientes, conservando-as em arquivo próprio".

Não podemos isentar o profissional de sua responsabilidade (Marques, 1994), pois conforme observamos na literatura, o arquivamento da documentação profissional é imperioso (Calvielli, 1997).

No que se refere ao período de arquivamento da documentação, os resultados apresentam uma dispersão crítica, a saber: um ano, 0\%; cinco anos, $25 \%$; dez anos, $25 \%$; quinze anos, $7 \%$; vinte anos, $11 \%$; e mais de vinte anos, $32 \%$.

Acreditamos que o desconhecimento da legislação Civil (Brasil, 1986a; Brasil, 1991) e Administrativa (CFO-174, 1994), bem como as contradições que envolvem a temática, contribuíram para a dispersão dos citados resultados entre as diversas opções propostas no questionário.

Nesse mesmo questionamento, referente ao período que o profissional arquiva a documentação, os profissionais cujas respostas foram 'vinte anos' e 'mais de vinte anos' estariam em consonância com o disposto nos termos do artigo 177 do Código Civil Brasileiro (Brasil, 1986a), onde a prescrição aplicável às ações pessoais é de 20 (vinte) anos. 
Já aqueles profissionais que responderam arquivar a documentação por dez anos (25\%), talvez estivessem seguindo a conclusão número cinco, apresentada aos profissionais sob a forma de sugestão, na publicação 'Prontuário Odontológico - Uma orientação para cumprimento da exigência do inciso VI do artigo 4ํ do Código de Ética Odontológica':

"O tempo de guarda do prontuário odontológico, por parte dos profissionais e clínicas particulares ou públicas, é de dez anos após o último comparecimento do paciente, ou, se o paciente tiver idade inferior aos dezoito anos à época do último contato profissional, dez anos a partir do dia que o paciente tiver completado ou vier a completar os dezoito anos" (CFO-174, 1994).

A par da publicação acima referida, expomos 0 artigo $2^{\circ}$ da Resolução CFM no 1.331/89:

"Após decorrido prazo não inferior a 10 (dez) anos, a fluir da data do último registro de atendimento do paciente, o prontuário pode ser substituído por métodos de registro, capazes de assegurar a restauração plena das informações nele contidas" (CFM-1331, 1989). Destarte, poderemos diferenciar o contido na publicação CFO-174/94 da Resolução CFM № 1.331/89: esta caracteriza a restauração plena das informações após decorrido o prazo de dez anos; na publicação, tal dispositivo não está caracterizado.

O período de arquivamento da documentação por cinco anos, opção de resposta de $25 \%$ dos profissionais, poderia estar relacionado com o que reza o Código Tributário Nacional em seu artigo 174: "a ação para a 
cobrança de crédito tributário prescreve em 5 (cinco) anos, contados da data de sua constituição definitiva".

Também poderíamos relacionar essa opção ao disposto no artigo 27 do Código de Defesa do Consumidor: "Prescreve em cinco anos a pretensão à reparação pelos danos causados por fato do produto ou do serviço (previstos na Seção II do Cap. IV), iniciando-se a contagem do prazo a partir do conhecimento do dano e de sua autoria" (Brasil, 1991).

Não há explicação de resposta para 0 arquivamento da documentação por quinze anos, que aparece com o resultado de $7 \%$.

Procurando elucidar essa procedente discussão, buscamos respaldo na literatura, que diz:

“...a ficha clínica deve ser guardada pelo menos 20 anos (sic), e não apenas 5, que é requisito da Receita Federal. O tempo maior está relacionado com normas legais, principalmente aquelas ligadas a problemas de responsabilidade profissional' (Silva, 1994, p.78).

Assim, constituindo a documentação odontológica o meio de prova, por excelência, para a comprovação do cumprimento da obrigação, pelo cirurgião dentista e sendo de 20 (vinte) anos o prazo de que dispõe o paciente para promover a ação pessoal (indenizatória por exemplo), a documentação deverá ser bem guardada pelo mesmo prazo pelo profissional (Calvielli, 1997).

Os resultados indicados também revelam e caracterizam as contradições que existem a respeito dessa temática. Retornando a eles, observamos que a soma das respostas arquivar a documentação por 'vinte 
anos' e 'mais de vinte anos' resultou $43 \%$ de profissionais que estão em consonância com a conclusão acima.

Já a somatória das respostas arquivar a documentação por 'cinco', 'dez' e 'quinze anos' totalizou 57\%. Esses dados salientam a necessidade de melhor orientar o profissional, mostrando-Ihe leis e hierarquia no atual ordenamento jurídico brasileiro.

Ainda, no Brasil, o número de processos contra médicos e dentistas é relativamente pequeno. Porém, com os movimentos de defesa do consumidor e com a atuação cada vez mais fiscalizadora da mídia, uma parcela maior da população brasileira tem exercido o seu direito de "cobrar" algo que não foi feito adequadamente pelo profissional (Farah \& Ferraro, 2000).

Veículos de comunicação estão diariamente disponibilizando canais de acesso ao público leigo com 0 intuito de facilitar denúncias. Exemplificamos: o recém-lançado 'site' da Associação Erro Médico do Brasil é o mais novo canal de denúncia*. A probabilidade de aumento das ações indenizatórias contra erros médico e odontológico é uma realidade.

Enfatizamos que a documentação profissional, cuidadosamente elaborada e arquivada, seguramente representará um valioso instrumento em defesa do próprio profissional. 


\subsection{Da responsabilidade profissional}

Hoje, a responsabilidade é enfocada como um dever do homem contemporâneo, dever esse que se alastra tanto para o aspecto moral como para o jurídico (Vasquez, 1989). É vista, também, como resultado da ação pela qual o homem expressa o seu comportamento, em face desse dever ou obrigação (Stoco, 1997).

Os deveres ou obrigações do homem, assim como seus direitos, são mencionados no artigo 20 do CCB (Brasil, 1986a): "Todo homem é capaz de direitos e obrigações na ordem civil'.

Caracterizando diversos elementos da responsabilidade civil do profissional liberal e buscando identificar seu nível de conhecimento a respeito dessa temática, perguntamos aos profissionais pesquisados se eles têm consciência plena da limitação do tempo para reclames à Justiça em relação ao tratamento odontológico e se conhecem o artigo 177 do CCB.

Primeiramente, para melhor entendimento do conceito 'pleno', pinçamos a definição formulada por Bueno*: "Pleno, adj. Cheio, completo, inteiro, perfeito".

Faz-se necessário também, esclarecermos o instituto da prescrição, visto que o tempo tem atuação direta na vida do homem: seja na vida biológica, na vida privada, na vida social ou nas suas relações civis. Também atua em relação aos direitos pertinentes ao homem.

\footnotetext{
*BUENO, F.S. Minidicionário da língua portuguesa. São Paulo: FTD, 1996.
} 
Dessa forma, o tempo pode ser requisito de nascimento de direitos; pode ser condição do exercício de direitos; pode ser, ainda, causa de extinção de direitos.

Quando o tempo faz nascer direitos, temos a prescrição aquisitiva; quando impede o exercício de direitos, temos a prescrição extintiva; e, quando o tempo extingue direitos, temos a decadência.

No âmbito da Responsabilidade Profissional, o cirurgião dentista deverá ater-se à prescrição extintiva.

Ferreira (1994), analisando prescrição e decadência no CDC, salientou que, ao cabo do prazo de cinco anos, a prescrição atingirá a pretensão do consumidor com base no $C D C$, mas não o impedirá de ajuizar outra ação, desde que não prescrita a prevista no art. 159 do CCB (Dias, 1979). Todavia, essa ação não possuirá as variadas benesses do CDC.

Em vista da dificuldade da questão, transcrevemos da literatura a hipótese da ação contra o construtor e o incorporador por defeito prejudicial à solidez e segurança do edifício, em que o prazo de cinco anos referido no artigo 1245 do CCB vem sendo reconhecido, segundo orientação jurisprudencial dominante, como simples garantia (grifo nosso), prescrevendo a ação indenizatória em vinte anos, nos termos do artigo 177 do mesmo diploma legal (Ferreira, 1994).

O paciente tem na ação pessoal, que protege os direitos de crédito (direito obrigacional), o instrumento para haver a reparação de eventual dano decorrente de tratamento odontológico (Calvielli, 1997). 
Portanto, nas relações que se estabelecem entre o cirurgião dentista e o paciente incide a prescrição extintiva aplicada sobre as ações pessoais, a qual é vintenária.

Antes de estabelecermos outros paralelos com a literatura, gostaríamos de tecer alguns comentários sobre os nossos resultados, provenientes dos dois primeiros questionamentos. Inicialmente, perguntamos ao profissional se ele tinha consciência plena do tempo de que o paciente pode dispor para reclames à Justiça em relação ao tratamento odontológico. Pudemos observar que $73,7 \%$ do total da amostra responderam não. Esse grande desconhecimento, somado ao resultado de um outro questionamento nosso, em que os profissionais responderam que retratariam os casos de recidivas no pós-contenção sem custas para o paciente $(70 \%$ do total da amostra), poderá talvez contribuir para uma insegurança na prática clínica, já que o profissional da nossa amostra demonstrou não estar perfeitamente ciente do tempo de que o paciente disporia para reclames à Justiça em relação ao tratamento odontológico.

De acordo com relatos existentes na literatura, tomando por referência a legislação alienígena, uma reclamação foi aceita dez anos póstratamento ortodôntico. Tal fato estaria relacionado à garantia dada por escrito ao paciente (Crosby \& Crosby, 1987). No Brasil, desconhecemos casos onde o paciente levaria o profissional a responder pela mesma ocorrência.

No que tange ao conhecimento do artigo 177 do CCB, a que já nos referimos, somente $16,8 \%$ do total da amostra respondeu conhecer esse 
dispositivo legal e suas implicações no exercício profissional. Esse dado é extremamente preocupante, haja vista que o artigo $3^{\circ}$ do Decreto-Lei $n^{\circ}$ 4.657, de 4 de setembro de 1942, Lei de Introdução ao Código Civil Brasileiro, instrui: "Ninguém se escusa de cumprir a lei, alegando que não a conhece".

Da análise da literatura depreende-se a necessidade de se atentar seriamente para o problema do desconhecimento que envolve o profissional com o nosso ordenamento jurídico. Em relação a esse fato, preocupa-nos a formação do profissional especialista, já que conteúdos programáticos correspondentes à Ética e Legislação Odontológica são normalmente ministrados em somente 15 (quinze) horas aula, que é a carga horária mínima estabelecida pela Resolução CFO 198, de 17 de novembro de 1995.

No que se refere a nossa indagação sobre o termo sublinhado 'As provas que porventura o cirurgião dentista apresente à Justiça são préconstituídas', a ocorrência de respostas negativa foi de $77,9 \%$. Como se sabe, prova pré-constituída é toda a documentação odontológica produzida oportunamente pelo profissional, isto é, elaborada ao longo da prática clínica.

Por conseguinte, a documentação de todas as fases da atuação do profissional é de suma importância (Silva, 1997). Como salienta a literatura, documentos médicos são diariamente elaborados, redigidos e guardados pelo médico (Louzã, 1995). Há um consenso dos vários autores que vêm escrevendo sobre o assunto, sobre a necessidade do profissional registrar os fatos que ocorrem diariamente no atendimento dos seus pacientes (Silva, 
1994; Pueyo, 1994; CFO-174, 1994; Louzã, 1995; Calvielli, 1997; Quest Consultoria e Treinamento, 1998). Esses registros, produzidos oportunamente, poderão vir a ser as provas apresentadas pelo profissional para comprovar a existência de um fato.

Portanto, o profissional que descuidar desse aspecto, prova documental, e vir a produzir uma documentação extemporânea, poderá suscitar a argüição de falsidade de que se ocupam os artigos 390 a 395 do Código de Processo Civil (Teixeira Filho, 1999).

Dentro da natureza da Responsabilidade Civil Odontológica, abordando a questão dos contratos, questionamos o profissional se ele adota algum modelo ou forma de contrato, se faz ressalvas no corpo do mesmo e se tem ciência da validade das mesmas.

Da análise da literatura depreende-se que a relação que se estabelece entre o profissional e seu paciente é de natureza contratual, derivada de um contrato estabelecido livremente entre paciente e profissional, a maioria das vezes de forma tácita (Silva, 1972; Dias, 1979; Kfouri Neto, 1996; Calvielli, 1997; Stoco, 1997; Oliveira, 1999; Theodoro Júnior, 1999). Na relação profissional-paciente, mesmo que não haja nada escrito, existe sempre a figura do contrato (forma tácita).

Todos somos consumidores e a nossa qualidade de vida depende da qualidade de nossos contratos (Prux, 1998). As idéias de operação econômica e circulação da riqueza ligam-se de forma implícita aos contratos, inclusive os de serviços fornecidos pelo cirurgião dentista. Os 
contratos celebrados entre cirurgião dentista e pacientes são chamados consensuais ou não solenes (contratos de locação de serviços).

Nossos resultados apuraram que $67 \%$ dos profissionais adotam algum modelo ou forma de contrato escrito. Particularizando esses profissionais que adotam contratos, indagamos se os mesmos fazem ressalvas no corpo do contrato. Constatamos uma cisão dos profissionais questionados em termos dessa indagação: $48 \%$ responderam 'sim', 45\% responderam 'não' e 7\% nada declararam. E daqueles que fazem ressalvas no corpo do contrato, $59 \%$ responderam que não estão cientes da validade das ressalvas.

Abordando o aspecto da proteção contratual no CDC (Brasil, 1991), destacamos o artigo 47:

"As cláusulas contratuais serão interpretadas de maneira mais favorável ao consumidor".

No contexto de um mundo globalizado, não raro encontramos 'modelos' de contrato que, em caso de dúvida ou conflito de posições, estabelecem cláusulas que julgam mais apropriadas para si ou em seu favor. Essas ressalvas presentes em tais contratos, mais propriamente denominadas cláusulas abusivas, surgem quando 0 fornecedor, aproveitando-se da ausência de negociação prévia, acaba por preestabelecer unilateralmente disposições contratuais que vêm prejudicar os direitos do consumidor. 
Atento a esses aspectos, destacamos que o artigo 51 do CDC (Brasil, 1991) traz em quinze incisos um rol bastante alentado de descrições de cláusulas abusivas. Consideramos todas de importância ímpar.

Prux (1998) mencionou aquelas que mais comumente aparecem nos contratos de serviços prestados por profissionais liberais, as quais transcrevemos a seguir:

- "as cláusulas que impossibilitem, exonerem ou atenuem a responsabilidade do fornecedor por vícios de qualquer natureza relativos aos serviços prestados;

- as que impliquem em renúncia ou disposição de direitos;

- as que transfiram responsabilidades a terceiros;

- as que estabeleçam obrigações consideradas iníquas, abusivas, que coloquem o consumidor em desvantagem exagerada, ou que sejam incompatíveis com a boa-fé ou a eqüidade;

- as que estabeleçam a inversão do ônus da prova em prejuízo do consumidor;

- as que determinem a utilização compulsória de arbitragem;

- as que autorizem o profissional fornecedor a, de forma unilateral, cancelar o contrato ou optar por concluí-lo ou não (embora obrigando o consumidor);

- as que permitam ao fornecedor, após a celebração do contrato, vir a modificar de forma arbitrária o seu conteúdo ou variar-Ihe o preço; 
- as que confiram ao fornecedor o direito de exigir os custos de cobrança da obrigação, sem que seja dado igual direito ao consumidor;

- as que subtraiam ao consumidor a opção de reembolso de quantias já paga" (destaque nosso).

Cumpre destacar que Prux, op.cit., p.319, comentou que nos contratos de serviços de ortodontia (grifo nosso), é habitual que se insiram cláusulas estabelecendo a perda de todas as parcelas pagas caso 0 paciente desista de continuar o tratamento.

Da literatura alienígena expomos colocações específicas a respeito do contrato e do pós-tratamento ortodôntico:

"Nosso contrato determina que o custo do tratamento cobre um conjunto de retentores e um ano de consultas de retenção. Ao final de um ano, enviamos uma carta ao paciente sugerindo continuar as visitas de retenção e explicamos que serão cobradas cada visita, radiografias ou retentores que se fizerem necessários" (Gorman in Mayerson et al., 1992, p.526).

"Em nosso contrato, incluímos uma taxa para retentores e doze meses de serviço de retenção, após o que nós cobramos pelas consultas de retenção e demais serviços prestados, tais como radiografais para checar os terceiros molares" (Zaytoun in Mayerson et al., 1992, p.526).

Os resultados referentes à indagação "Como considera a responsabilidade civil do cirurgião dentista, especificamente quanto ao 
tratamento ortodôntico?" trouxeram-nos uma grande preocupação, pois as respostas revelaram que $60 \%$ dos profissionais consideram a natureza da obrigação como sendo de resultado. Outros $29 \%$ responderam como sendo de meio e $11 \%$ não se manifestaram.

Os dados encontrados na literatura apontam ser bastante controvertida a questão jurídica da responsabilidade profissional (Diniz, 1990; Calvielli, 19997; Prux, 1998). Há os que acreditam ser essa responsabilidade de resultado (Bittar, 1991; Araújo, 1991) e há os que a configuram de meio (Graça Leite, 1962; Kfouri Neto, 1990). Também observamos que algumas áreas são taxativamente enquadradas como obrigação de resultado: na realização de exames radiográficos, exames laboratoriais, cirurgia plástica puramente contratual (Theodoro Júnior, 1999).

Analisando Responsabilidade Civil e sua interpretação jurisprudencial, com relação ao cirurgião dentista, observamos que a obrigação de resultado mais se evidencia quando envolve a colocação de prótese, restauração, limpeza, voltadas para o aspecto estético (Stoco, 1997).

Encontramos também na literatura uma tentativa de agrupar as especialidades odontológicas a partir de sua natureza obrigacional (França, 1993; Oliveira, 1999; Farah \& Ferraro, 2000).

Acreditamos que tentar identificar um elenco das especialidades da odontologia, caracterizando quais seriam de resultado, de meio ou, parte de meio e parte de resultado, seria um exercício dispensável, já que o próprio 
Código Civil estabelece o termo culpa; portanto, se de meio ou de resultado, caberá à análise de cada caso em particular.

Porém, cabe um alerta ao profissional que, em qualquer que seja o serviço prestado ao consumidor, venha a expressar garantia de um determinado resultado, porquanto deverá o mesmo responder cumprindo o resultado prometido.

Em vista do que abordamos na temática referente à documentação profissional e, procurando conhecer o que ocorre atualmente, expusemos ao profissional a seguinte circunstância: quando o paciente solicita retirada de documentos da clínica, qual procedimento é adotado? Nossos dados revelam que $83 \%$ dos profissionais entregam a documentação com assinatura do termo de retirada, outros $16 \%$ entregam a documentação sem nenhuma comprovação da retirada.

Como já ressaltamos anteriormente, a literatura afirma peremptoriamente a importância da documentação profissional (Crosby \& Crosby, 1987; Machen, 1989; Machen, 1992; Cardozo, 1993; Louzã, 1995; Silva, 1997; Calvielli, 1997; Fortes, 1998; Aguiari et al, 1998; Farah \& Ferraro, 2000).

A especialidade ortodontia e ortopedia facial tem como característica clássica primar pela documentação clínica. O que nos levou a tal indagação foi a preocupação do controle no pós-tratamento e a possibilidade de retratamento ortodôntico. 
Porém, o paciente tem direito ao acesso a informações relativas ao que the diz respeito. Baseamos nossa assertiva no habeas data expresso na Constituição Federal (Brasil, 2000):

"Art. 5\%.

LXXII - conceder-se-á habeas data:

a) para assegurar o conhecimento de informações relativas à pessoa do impetrante, constantes de registros ou banco de dados de entidades governamentais ou de caráter público;

b)

Do Código de Defesa do Consumidor (Brasil, 1991), constitui crime contra as relações de consumo:

"Art. 72. Impedir ou dificultar o acesso do consumidor às informações que sobre ele constem em cadastro, banco de dados, fichas e registros:

Pena - Detenção de seis meses a um ano ou multa".

Pronunciando-se a respeito do assunto, Moraes (1995) comentou: " $A$ necessidade de conhecimento de todos esses pontos só aparece quando a relação médico/paciente está abalada. Se tudo evolui bem e o doente sarar, raramente há algum questionamento".

Acreditamos que na relação cirurgião dentista/paciente, o exposto acima se aplica na íntegra. Desse modo, o paciente tem direitos legais que precisam ser do conhecimento do CD e por ele cumpridos, nas situações necessárias. 


\subsection{Do pós-tratamento ortodôntico}

Como já salientado, na medida em que a população está cada vez mais conscientizada sobre os seus direitos como consumidora, aumentam as necessidades do cirurgião dentista conhecer as exigências legais que cercam a sua atividade (Quest Consultoria e Treinamento, 1998).

No caso da Ortodontia, isso é premente diante de um conjunto de recomendações e restrições que se fazem no pós-tratamento (Reidel, 1969; Proffit, 1986; Burstone, 1994; Gorman, 1994; Alexander, 1997; Blake \& Bibby, 1998; Sachet, 1999).

Durante muitos anos publicou-se uma grande quantidade de livros que tratam dos temas relacionados às diversas etapas do tratamento ortodôntico. Alguns fatores responsáveis pela contenção e pela estabilidade não receberam a atenção que outras áreas tiveram, como por exemplo: o diagnóstico, o plano de tratamento e a biomecânica (Burstone, 1994).

Riedel (1976) afirma que os ortodontistas conhecem muito pouco sobre os efeitos da contenção prolongada versus contenção relativamente breve e, seja qual for a maloclusão, ela revelará as condições para a estabilidade final da dentição.

Na prática clínica, as estratégias de tratamento e as relações obtidas intra e interarcos deverão ser maximizadas, pois as probabilidades de estabilidade a longo prazo se diferem e nós, ortodontistas, devemos nos esforçar para melhorar a estabilidade nas etapas de contenção e póscontenção. 
6.4.1 Adotar como rotina aparelhos de contenção

Comparando as publicações a respeito do assunto com os resultados do nosso primeiro questionamento, "Adota como rotina aparelhos de contenção?", observamos que há uma convergência de conduta, haja vista que todos os profissionais responderam empregar tais dispositivos no póstratamento.

6.4.2 Período recomendado de uso dos aparelhos de contenção

Quanto ao período que o profissional recomenda o uso dos aparelhos de contenção, $84 \%$ dos respondentes recomendaram que o paciente usasse os mesmos por tempo integral. Essa instrução reflete o cuidado e a atenção que o profissional tem para com o aspecto da contenção. Outros resultados do mesmo questionamento apontaram que $8 \%$ do total da amostra instruem seus pacientes a utilizarem os aparelhos de contenção durante o período noturno e somente $2 \%$ no período diurno. Os demais $6 \%$ ficaram distribuídos entre as seguintes composições: noturno e integral (4\%), diurno e noturno (1\%), e diurno e integral (1\%). Ressaltamos que as três últimas opções não constavam do questionário. 
6.4.3 Tempo recomendado de uso dos aparelhos de contenção

Em relação ao tempo recomendado de uso dos aparelhos de contenção, conforme os resultados apresentados na Tabela 5.2, pode-se constatar que $65 \%$ dos profissionais se distribuíram entre as opções: um ano (28\%), um ano e meio (18\%) e dois anos (19\%). Os demais resultados, compreendidos entre dois anos e meio (2\%), três anos (3\%), até cinco anos $(8 \%)$ e mais tempo (14\%), estiveram relacionados a diversos fatores tais como:

a) pacientes em crescimento;

b) paciente adulto com recomendação de uso permanente à noite;

c) casos de mordida cruzada posterior em pacientes adultos;

d) 'splintagem' em paciente adulto com reabsorção óssea alveolar;

e) orientação para uso da contenção por toda vida.

Com base nos dados acima apresentados, associamos o período recomendado de uso dos aparelhos de contenção com o tempo de permanência da contenção. Disso resultou que $84 \%$ dos profissionais recomendam o uso dos aparelhos de contenção em período integral, pelo tempo compreendido entre um a dois anos, que é o indicado por $65 \%$ dos profissionais consultados.

Os ortodontistas têm diferentes filosofias de contenção. Encontramos na literatura revista desde aqueles que propõem não conter, até outros que sugerem a contenção por toda a vida do paciente. 
Entre os diversos posicionamentos encontrados na literatura, merecem ser destacados:

- a variabilidade do tempo que o paciente deve usar os aparelhos de contenção, tempo esse que depende de diversos fatores, como já se salientou (Strang, 1958);

- a necessidade de contenção por um período de tempo maior, uma vez que as fibras principais do ligamento periodontal se reorganizam após um período de oito a nove semanas e as estruturas supra-alveolares podem permanecer estiradas durante um período mais longo (Reitan, 1969);

- as dificuldades em manter a contenção continuamente; em determinar com exatidão quantos meses ou anos, e a quantidade de horas por dia em que as contenções removíveis deveriam ser usadas após o tratamento ortodôntico (Reidel, 1969; e Joondeph \& Reidel, 1985);

- o uso da contenção fixa ou removível para sempre (Little et al., 1988);

- o uso da contenção fixa ou removível por toda a vida (Little \& Riedel, 1989); 
- a contenção a longo prazo - dinâmica, não estática, pois "... se pode filosofar que na morfologia humana nada permanece estacionário. O envelhecimento é um processo de alteração bem documentado. O ajuste das dentições e as alterações nas relações dentárias são bem conhecidas, mesmo em indivíduos sãos" (Nanda \& Nanda, 1992);

- a consideração de que a contenção é tão importante quanto o tratamento ativo para produzir um resultado excelente e duradouro. Alexander temporizou a contenção como sendo um processo de três anos, durante o qual o clínico deve ter o controle do caso e estimular o paciente a continuar usando os dispositivos de contenção (Alexander, 1994);

- a filosofia, exposta pelo mesmo autor, de que quanto maior for o tempo no qual a posição dos dentes tratados pode ser mantida, mais estável se tornará a oclusão. Nesse trabalho, o autor abordou contenção como sendo um processo de quatro anos e comentou que o único modo de se garantir que uma contenção obtenha sucesso é aquele no qual o paciente tenha alcançado oclusão equilibrada (Alexander, 1997). 
Comparando os dados desses trabalhos e confrontado-os com os nossos, verifica-se que os mesmos não são congruentes, muito embora tenhamos obtido $14 \%$ de respostas recomendando mais tempo de uso.

\subsubsection{Tempo que o profissional mantém o retentor inferior colado}

Quanto aos resultados apresentados na Tabela 5.3, específicos ao tempo que o profissional mantém o retentor inferior colado, observa-se uma concentração nas respostas. Há um consenso em manter o retentor inferior colado até cinco anos (29\%) ou mais tempo (41\%), totalizando $70 \%$ dos resultados.

A respeito dos nossos resultados e o posicionamento encontrado na literatura, destacamos:

- Williams (1985) analisou, durante vinte e um anos, pacientes tratados que não usaram contenção inferior. Afirmou ainda existirem seis chaves para a oclusão, essenciais para que a contenção inferior pudesse ser eliminada, as quais foram já apresentadas na literatura revista.

- Haas (1980) preconizou manter o retentor inferior colado por seis a oito anos.

- Little et al. (1981) avaliaram o alinhamento ântero-inferior em sessenta e cinco casos com dez anos de pós-contenção. 
Enfatizaram que a resposta a longo prazo do alinhamento inferior foi variável e imprevisível, pois dois terços da sua amostra apresentaram alinhamento ântero-inferior insatisfatório póscontenção.

- Mucha (1987) dedicou especial atenção ao alinhamento dos incisivos inferiores após o término do tratamento ortodôntico. Constatou que quanto maior o período de contenção, maior é a tendência de ocorrer a recidiva.

- A realidade dos nossos conhecimentos atuais, escreveu Burstone (1994), é que nenhuma forma de tratamento garante uma absoluta estabilidade, nem o caso tratado sobre o melhor padrão pode assegurar por si mesmo a estabilidade. Isto não sugere, já que não conhecemos todos os numerosos fatores que produzem instabilidade, que nossos objetivos de tratamento devam ignorar uma oclusão estável e que a contenção permanente é inevitável.

Concomitante aos nossos resultados, pode-se asseverar que há uma maior atenção à problemática da estabilidade no segmento ântero-inferior, já que as porcentagens indicadas vêm denotar uma preocupação, um cuidado todo especial em relação a esse dogma da ortodontia.

Pacientes hão de ser muito bem esclarecidos a respeito do póstratamento ortodôntico e possíveis alterações nessa fase. 
6.4.5 Conduta adotada pelo profissional nos casos de recidiva durante o período de contenção

Com relação às recidivas em ortodontia, Alexander (1997) teceu considerações a respeito do ortodontista que, supostamente, não teria tido em seu consultório experiência com esse tipo de ocorrência, como sendo aquele profissional que não continuou a ver seus pacientes por vários anos após o tratamento ativo. Em outras palavras, concluiu o autor, a recidiva existe, mas ele não sabe disso.

O tipo clássico de recidiva está bem documentado na literatura. Exemplificando, Burstone (1994) inclue o apinhamento, o espaçamento entre os dentes, o retorno da mordida aberta ou profunda, a ausência de estabilidade na correção da classe II ou classe III, a falta de estabilidade nos casos de sub-divisão e em geral, um retorno do mal alinhamento dentário.

Ainda Alexander (1997) comentou que a maioria das pesquisas na área da ortodontia sugere que os dentes anteriores inferiores apinhados ou girados são, provavelmente, os que mais apresentam recidivas. Em relação à reabertura de mordida em um caso de mordida aberta, o autor considerou como principais causas de recidiva a não cooperação por parte do paciente em utilizar aparelhos de contenção e a presença de maus hábitos, como por exemplo: chupar os dedos, interposição lingual e respiração bucal.

A literatura também baliza condutas quanto ao aspecto do paciente em crescimento que, como foi referido na revista da literatura, pode ser um fator desencadeante e vir a provocar recidivas significativas. 
Quanto às condutas adotadas pelos profissionais nos casos de recidiva durante o período de contenção, elaboramos seis opções de resposta sob o contexto da reabilitação oclusal. Também incluímos no questionário as opções 'cirurgia' e 'nenhum procedimento é adotado'.

Pelos dizeres de Vartan (1974), o conceito de reabilitação oclusal é:

"O conjunto de procedimentos terapêuticos que a odontologia utiliza para transformar uma oclusão patológica do ponto de vista funcional, em uma oclusão fisiologicamente normal, em harmonia morfofuncional com o resto do sistema estomatognático particular de cada indivíduo. O objetivo final de toda reabilitação oclusal é a obtenção de uma oclusão ótima e, os procedimentos utilizados individual ou conjuntamente são três: desgaste seletivo; ortodontia- ortopedia e; reconstrução olcusal' (Vartan, 1974, p.185-186 ).

Nossos resultados revelaram que $49 \%$ dos profissionais adotam o retratamento ortodôntico como conduta nos casos de recidiva durante o período de contenção. Nas diversas circunstâncias em que ocorre a recidiva, esse resultado demonstra que o ortodontista procura resolver a questão propondo ao paciente o retratamento ortodôntico.

O segundo resultado de maior expressão foi o ajuste oclusal (24\%). As regras para o ajuste oclusal através da coronoplastia ou desgastes seletivos têm sido exaustivamente discutidas por renomados pesquisadores. Considerando o ajuste oclusal sob a ótica da ortodontia, Baptista (1993) 
comentou que o paciente que finalizou seu tratamento aos 15 anos deve ter sua oclusão analisada diferencialmente daquele paciente adulto com mutilações dentárias.

A par dos problemas já citados, Conti \& Sábio (1999) revisaram diversas teorias e conceitos atuais no que tange à utilização do ajuste oclusal como método terapêutico na finalização de casos ortodônticos. Os autores concluíram que pode não ser necessário o ajuste oclusal após a terapia ortodôntica, principalmente em adolescentes, desde que se estabeleça uma oclusão com os princípios gnatológicos.

Não nos detivemos em questionar técnicas de tratamento ou faixa etária de pacientes que foram tratados pelos profissionais que compuseram a nossa amostra, já que este não se constituía o escopo do nosso trabalho.

O terceiro destaque dos nossos resultados foi para com as reconstruções dentárias. A reconstrução estética com o auxílio da dentística foi a opção de $16 \%$ dos profissionais. Com novas técnicas e materiais restauradores, a dentística vem ao encontro das necessidades inerentes ao pós-tratamento ortodôntico.

Em igual porcentagem, outros recursos também foram dignos de confiança do ortodontista, principalmente as reconstruções, que assim se expressaram: reconstruções estéticas com o auxílio da prótese (3\%), reconstruções oclusais com o auxílio da dentística (3\%) e reconstruções oclusais com o auxílio da prótese (3\%). O emprego da cirurgia frente às recidivas durante o período de contenção foi a conduta menos adotada $(2 \%)$. 
Ainda abordando condutas adotadas nos casos de recidiva durante o período de contenção, os dados coletados revelaram que todos os profissionais assinalaram adotar algum procedimento frente a essa ocorrência. Comprova-se tal assertiva, pois a porcentagem na opção ‘nenhum procedimento é adotado' foi $0 \%$.

Especificamente quanto à conduta adotada nos casos de recidiva durante o período de contenção, os dados caracterizam a recidiva como uma possibilidade real no pós-tratamento ortodôntico e também apontam os procedimentos mais adotados.

6.4.6 Freqüência com que o profissional supervisiona o paciente no período pós-contenção

Já em 1919 Hawley se preocupava com o período pós-tratamento ortodôntico. Foi enfático ao declarar que, devido à dificuldade, daria a metade dos seus honorários profissionais a alguém que se responsabilizasse pela contenção de seus casos.

Observa-se, hoje em dia, uma grande quantidade de pacientes que buscam tratamento ortodôntico (Gorman, 1994). Nesse tratamento, o tempo produtivo do profissional volta-se quase que exclusivamente para os pacientes em fase corretiva. $O$ controle e a supervisão do paciente na fase de pós-contenção promove-se através de rápidas consultas, em que o profissional normalmente não dispende mais do que alguns minutos durante o exame. Considere-se também que o retorno desse paciente está mais 
condicionado à iniciativa dele deslocar-se até o profissional do que deste propriamente promover a saúde bucal do seu paciente.

Assim, consideramos expressiva a porcentagem dos profissionais que responderam supervisionar o paciente de ano em ano (81\%) no período pós-contenção. Por outro lado, 8\% responderam que não supervisionam o paciente nesse período e $6 \%$ dos profissionais que compuseram a amostra simplesmente não responderam essa questão.

As demais porcentagens ficaram assim distribuídas: 2\% supervisionam de dois em dois anos; $1 \%$ supervisiona de três em três anos; e 1\% também, faz essa supervisão de dez em dez anos. Conforme já referido nos nossos resultados, enquadrou-se em 1\% a seguinte resposta: supervisão anual do paciente em crescimento e supervisão de dois em dois anos em relação ao paciente adulto. A opção de supervisionar o paciente de cinco em cinco anos não foi assinalada por nenhum dos profissionais da amostra.

6.4.7 Conduta adotada pelo profissional nos casos de recidiva após o período de contenção

Pesquisamos também a conduta adotada pelo profissional nos casos de recidiva após o período de contenção. A literatura caracteriza esse 
período como sendo aquele em que o paciente não está mais usando aparelhos de contenção fixo ou removíveis (Little et al., 1981; Little et al., 1988; Nanda \& Nanda, 1992; Gorman, 1994; Sachet, 1999).

Há um consenso na literatura de que se deve atentar mais para esse período, o do pós-tratamento ortodôntico (Riedel, 1976; Nanda \& Burstone, 1994; Burstone, 1994; Alexander, 1997).

Estabelecendo um paralelo entre a revisão da literatura no póstratamento ortodôntico (Moyers, 1979; Nanda \& Zernik, 1994; Sadowsky, 1994; Blake \& Bibby, 1998), com o nosso enfoque dado à questão da recidiva após o período de contenção, salientamos que algumas opções de resposta a essa temática foram embasadas na responsabilidade profissional do cirurgião dentista (Arbenz, 1959; Ronchi, 1993; Marques, 1994; Menezes, 1994; Stoco, 1997; Machado, 2000).

Nossos resultados demonstram que a conduta adotada por $70 \%$ dos profissionais que compuseram a amostra é informar ao paciente que a recidiva após o período de contenção é uma circunstância 'natural' e propor a ele o retratamento ortodôntico. Destacamos que o pesquisador não especificou um intervalo temporal, caracterizando somente recidiva após o período de contenção.

Essa conduta corrobora com os dados encontrados quando do questionamento a respeito da recidiva ainda no período de contenção, pois nossos resultados apontaram o retratamento ortodôntico como sendo a conduta mais adotada por $49 \%$ dos respondentes. 
Obviamente a inestabilidade tem múltiplas causas e o ortodontista deve evitar explicações simplistas (Burstone, 1994).

No segundo e terceiro resultados, abordando ainda a conduta do profissional frente à recidiva no período pós-contenção, 18\% responderam informar ao paciente que devido a circunstâncias atípicas há necessidade de retratamento ortodôntico, cobrando-Ihe novos honorários profissionais; e $4 \%$ responderam informar somente que seria necessário retratar o caso clínico e cobrar novos honorários.

Antes de discutirmos os demais resultados, apresentaremos comentários encontrados nos poucos trabalhos que fazem referência à cobrança de honorários profissionais e ao retratamento ortodôntico:

- Gorman (1994) expôs que se o profissional cometer o erro de não cobrar pela contenção e pelo retratamento, permitirá que os pacientes abandonem o tratamento depois de um ou dois anos de contenção, levando então o ortodontista a pensar que está tudo bem, senão esses pacientes teriam voltado;

- Alexander (1997) comentou que a grande questão que existe em relação a refazer um tratamento ortodôntico é sobre a responsabilidade financeira. O ortodontista assumirá a responsabilidade por todos os custos? O paciente pagará por eles? Há um compromisso? Em resumo, o autor propôs que o tratamento seja refeito com uma taxa diferenciada, quando o paciente não 
usou o aparelho de contenção ou não seguiu as instruções fornecidas pelo profissional.

Após esses posicionamentos encontrados na literatura, evidenciamos nesta discussão a preocupação do profissional em controlar o paciente no pós-contenção, responsabilizando-o financeiramente perante o retratamento ortodôntico.

Muito embora as demais opções de resposta expressem menores porcentagens, acreditamos que os resultados possam ainda espelhar condutas adotadas pelo profissional frente à recidiva no período póscontenção. Nesse sentido, $6 \%$ informam ao paciente que é uma circunstância 'natural'; $1 \%$ informam ao paciente que é uma circunstância 'natural' e que nenhum procedimento clínico seria adotado; e 1\% nada informam ao paciente, retratando o caso clínico. A opção "nada informar ao paciente e não retratar o caso clínico" não foi adotada por nenhum dos profissionais que compuseram a nossa amostra.

6.4.8 Conduta adotada pelo profissional perante o paciente insatisfeito com os resultados do tratamento ortodôntico 
Para fundamentarmos essa questão, reportamo-nos à Quest Consultoria e Treinamento:

"O profissional da área de saúde - principalmente o dentista e o médico - possui um conhecimento técnico específico, o qual ele ‘vende’ a pessoas físicas e jurídicas e é responsável pela qualidade deste serviço, respondendo civil e criminalmente por seus atos profissionais" (Quest Consultoria e Treinamento, 1998, p.9).

A responsabilidade profissional do cirurgião dentista poderá ser enquadrada nos artigos 159, 1525 e 1545 do CCB e integralmente nos preceitos do Código de Defesa do Consumidor (Vasconcelos, 1970; Séllos, 1994).

Da doutrina, destacamos a colocação de Séllos:

"Responsabilidade civil é a obrigação de uma pessoa física ou jurídica indenizar dano causado a outrem, com a intenção de restabelecer o equilíbrio patrimonial ou moral decorrente desse dano" (Séllos, 1994, p.159).

Já da literatura médica, extraímos abordagens específicas que, pari passo, podem muito bem servir de exemplo à odontologia.

"O que induz o paciente a uma ação legal, quando ocorre uma complicação, muitas vezes é a atitude do cirurgião e do pessoal da equipe frente a ela, mais do que a sua própria ocorrência. Na imensa maioria das vezes ele aceita a complicação pós-operatória se o cirurgião demonstra a sua preocupação e interesse e o mantém informado das medidas tomadas “ (Maciel, 1997, p.23). 
Sob os aspectos acima expostos e analisando o conjunto de respostas à questão formulada, o primeiro resultado possivelmente demonstra a preocupação do profissional em ver-se envolvido numa lide jurídica, pois $55 \%$ responderam que procurariam, de qualquer forma, evitar que o paciente agilizasse ação de ordem cível.

O segundo resultado tende a revelar outras condutas que seriam adotadas pelo profissional perante o paciente insatisfeito com os resultados do tratamento ortodôntico. Com $41 \%$ do total de respostas, as condutas mais especificadas foram:
a) dialogaria com o paciente;
b) procuraria resolver o problema com o paciente;
c) procuraria identificar a (s) causa (s) da insatisfação;
d) tentaria um acordo com o paciente;
e) obteria opiniões com outros ortodontistas;
f) retrataria ortodonticamente sem cobrar novos honorários profissionais.

Aparentemente as condutas especificadas como resposta à temática sugerem que os profissionais buscam o entendimento com o paciente, haja vista que duas outras opções de resposta presentes no corpo do questionário não foram assinaladas: desconsideraria os reclames do paciente e perante os reclames do paciente the retribuiria com a colocação 'procure seus direitos'. 
A busca de entendimento com o paciente é importante no sentido de se evitar o litígio. E a própria literatura reconhece isso, ao mostrar caminhos para se evitar o litígio (Machen, 1992).

Antes de estabelecermos outros paralelos com a literatura, nos poucos trabalhos em que é possível fazer alguma comparação com os nossos resultados, gostaríamos de tecer algumas considerações:

- É consenso jurídico a obrigação do cirurgião dentista reparar o dano, independentemente da existência de um contrato firmado entre as partes.

- Cabe ao lesado comprovar a ação ou omissão que desencadeou o dano e ao profissional, que não agiu culposamente.

Em outro resultado, constata-se que $3 \%$ dos profissionais responderam solicitar ao paciente que procurasse outro profissional.

Cabe novamente, destacarmos Machen (1992). O autor abordou diversos aspectos legais na ortodontia e apresentou uma estatística na qual $47 \%$ dos processos contra ortodontistas estariam baseados numa deficiente interação entre o ortodontista e sua equipe com o paciente ou os pais desse paciente; e $\mathbf{4 0 \%}$ dos processos seriam iniciados a partir do resultado crítico de um segundo ortodontista (destaque nosso).

Sob certos aspectos, seria temerosa a conduta adotada pelos $3 \%$ de profissionais que assim responderam.

A ocorrência de $1 \%$ para a resposta de que o profissional comunicaria o fato ao seu advogado e o contrataria, mesmo que ainda numa condição pré-litigiosamente, sugere certa preocupação do profissional para com 
possíveis desdobramentos futuros, nos quais caberia a interposição de uma ação pessoal por parte do reclamante.

6.4.9 Profissional envolvido numa ação de responsabilidade civil

A respeito do envolvimento do profissional numa ação de responsabilidade civil, Farah \& Ferraro alertam:

"O número de processos contra médicos e dentistas é relativamente pequeno no Brasil. Em outros países, como nos Estados Unidos, estes processos fazem parte das preocupações de todo profissional. Mas, com os movimentos de defesa do consumidor e, com a atuação cada vez mais fiscalizadora da mídia, uma parcela maior da população brasileira tem exercido seu direito de 'cobrar' algo que não foi feito adequadamente pelo profissional. Isto significa que existe, como já ocorreu em outros países, a probabilidade de aumento das ações indenizatórias contra erros médicos e odontológicos" (Farah \& Ferraro, 2000, p.11).

Conforme visto, o aumento do número de ações cíveis contra o profissional nos levou a questionar o ortodontista se este já estivera envolvido numa ação de Responsabilidade Civil. Como resposta, 4,2\% da amostra afirmou que já estivera envolvida numa ação de tal Responsabilidade.

Este trabalho não teve por escopo analisar o processo de responsabilidade civil. Porém, vale ressaltar que a prescrição para 
propositura de ação pessoal é vintenária (Art. 177 do CCB), ou seja, permite que um processo de responsabilidade civil seja impetrado até vinte anos após a ocorrência do ato praticado pelo cirurgião dentista.

Acreditamos que acompanhar o paciente no pós-tratamento também é um dever do profissional na Ciência e Arte de Angle. 


\section{CONCLUSÕES}

A análise e discussão dos resultados obtidos no presente trabalho permitiram-nos concluir que:

1. A literatura ortodôntica é controversa no que tange a tempo, técnicas e dificuldades inerentes ao pós-tratamento ortodôntico.

2. O profissional que compôs a amostra apresenta o seguinte perfil: ortodontista na faixa etária dos 30 aos 49 anos, maioria do sexo masculino, formação acadêmica em nível de especialista e clinicando nas cidades maiores.

3. Todos os profissionais da amostra solicitam documentação inicial; porém, ao término do tratamento ortodôntico, deixam de solicitá-la (somente $79 \%$ a solicitam). Essa documentação é arquivada quase que pela totalidade dos profissionais (99\%). No entanto, o período de guarda dessa documentação é díspar, pois $43 \%$ responderam arquivá-la por vinte ou mais anos e outros $50 \%$ se dividiram entre os períodos de cinco e dez anos. $O$ 
desconhecimento da Legislação por parte do profissional e as contradições que envolvem a temática contribuíram para a dispersão desses resultados.

4. A maioria dos profissionais questionados $(60 \%)$ considera a Responsabilidade Civil do ortodontista como de Resultado.

5. Também a maioria desses profissionais (67\%) adotam contratos; fazem ressalvas nos contratos (48\%); porém, $59 \%$ não estão cientes da validade das mesmas perante o Código de Defesa do Consumidor.

6. No pós-tratamento, durante o período de contenção, $84 \%$ dos profissionais que constituem a amostra recomendam o uso dos aparelhos de contenção em período integral e, segundo $65 \%$ da amostra, pelo tempo compreendido entre um a dois anos.

7. Nos casos de recidivas, propõem retratamento ortodôntico (49\%). Já as recidivas que ocorrem no pós-contenção, segundo 70\% da amostra, são informadas como circunstância natural e recebem como propositura o retratamento ortodôntico (sem custas para o paciente).

8. Perante o paciente insatisfeito com os resultados do tratamento ortodôntico, a maioria dos profissionais (55\%) respondeu que procuraria, de qualquer forma, evitar que o mesmo impetrasse ação de ordem cível. 
9. O desconhecimento da Legislação e a existência de controvérsias no póstratamento ortodôntico podem estar levando o ortodontista a responder civilmente pelas movimentações dentárias e alterações neuromusculares que ocorrerem nessa fase. 
ANEXOS 
ANEXO 1 


\section{REFERÊNCIAS BIBLIOGRÁFICAS}

1 AGUIARI, M.; BERTOLDI, S.; COLASANTO, S.; MASTRORILLI, M; SALVATI, V. II consenso informato in odontoiatria. Roma: Ordine dei Médici e degli Odontoiatri, 1998. Versione preliminare n.2.

2 ALEXANDER, R.G. Tratamiento y contención para la estabilidad a largo plazo. In: NANDA, R.; BURSTONE, C.J. Contención y estabilidad en ortodoncia. Buenos Aires: Editorial Médica Panamericana, 1994. Cap. 8. p.93-109.

3 ALEXANDER, R.G. A disciplina de Alexander: filosofia e conceitos contemporâneos. São Paulo: Santos, 1997. Cap. 14. p.431-442.

4 ALMANAQUE abril. 25.ed. São Paulo: Editora Abril, 1999. p.99.

5 ARBENZ, G.O. Introdução à odontologia legal. São Paulo: Linográfica, 1959. 248p.

\footnotetext{
* De acordo com NBR-6023 da Associação Brasileira de Normas Técnicas, 1989. Abreviatura de periódicos segundo "Index to Dental Literature" e "Index Medicus".
} 
6 ARAÚJO, A.L.M. Responsabilidade do cirurgião dentista. In: BITTAR, C.A. Responsabilidade civil médica, odontológica e hospitalar. São Paulo: Saraiva, 1991. p.155-175.

7 ASSOCIAÇÃO BRASILEIRA DE ORTODONTIA E ORTOPEDIA FACIAL. Catálogo nacional de ortodontia - 1999/2000. Maringá: Dental Press, 1999. p.82-99.

8 BAPTISTA, J.M. Procedimentos de Finalização e Contenção Ortodônticas. In: PETRELLI, E. Ortodontia contemporânea. 2.ed. São Paulo: Sarvier, 1993. Cap.19. p.331-370.

9 BERTOLDI, M.M. Responsabilidade contratual do fornecedor pelo vício do produto ou serviço. Rev. Dir. Cons., n.10, p.126-143, abr./jun. 1994.

10 BEVILAQUA, C. Código civil dos Estados Unidos do Brasil. 9.ed. Rio de Janeiro: Francisco Alves, 1954. v.5. p.134.

11 BITTAR, C.A. Responsabilidade civil médica, odontológica e hospitalar. São Paulo: Saraiva, 1991. p.1-31.

12 BLAKE, M.; BIBBY,K. Retention and stability: a review of the literature. Am. J. Orthod. Dentofac. Orthop., v.114, n.3, p.299-306, Sept. 1998. 13 BOUZON, E. O Código de Hammurabi. 6.ed. Petrópolis: Vozes, 1998. 
14 BRASIL. Código civil brasileiro. São Paulo: Saraiva, 1986a. 1086p.

15 BRASIL. Código de defesa do consumidor. São Paulo: Atlas, 1991. 50p. [Manuais de Legislação, n.33].

16 BRASIL. Código penal brasileiro. São Paulo: Saraiva, 1986b. 850p.

17 BRASIL. Constituição Federal. 5.ed. São Paulo: Revista dos Tribunais, 2000. 266p.

18 BURSTONE, C.J. Perspectivas en la estabilidad de la ortodoncia. In: NANDA, R.; BURSTONE, C.J. Contención y estabilidad en ortodoncia. Buenos Aires: Editorial Médica Panamericana, 1994. Cap. 3. p.31-44.

19 CÁCERES, E. Os direitos básicos do consumidor - uma contribuição. Rev. Dir. Cons., n.10, p.61-76, abr./jun. 1994.

20 CALVIELLI, I.T.P. Responsabilidade profissional do cirurgião dentista. In: SILVA, M. (Coord.) Compêndio de odontologia legal. Rio de Janeiro: Medsi, 1997. Cap. 23. p.399-411.

21 CARDOZO, H.F. Verificação da ocorrência de traumatismos faciais e de elementos dentários, em ocupantes de veículos, decorrentes de 
acidentes de trânsito. São Paulo, 1990. 102p. Dissertação (Mestrado em Traumatologia Buco-Maxilo-Facial) - Faculdade de Odontologia da Universidade de São Paulo.

22 COELHO, F.U. O empresário e os direitos do consumidor. São Paulo: Saraiva, 1994. p.98.

23 CONSELHO FEDERAL DE MEDICINA (CFM). Resolução CFM № 1331 de 21.09.1989. Brasília: CFM, 1989. [mimeografado].

24 CONSELHO FEDERAL DE ODONTOLOGIA (CFO). Código de ética odontológica. Resolução CFO no 179 de 19.12.1991. Rio de Janeiro: CFO, 1998. 20p.

25 CONSELHO FEDERAL DE OdONTOLOGIA (CFO). Prontuário odontológico: uma orientação para cumprimento da exigência contida no inciso VI do art. 4º do Código de Ética Odontológica. Portaria nº 174 de 07.12.1992. Rio de Janeiro: CFO, 1994. 20p.

26 CONTANDRIOPOULOS, A. P.; CHAMPAGNE, F.; POTVIN, L.; DENIS, J.L.; BOYLE, P. Saber preparar uma pesquisa. 2.ed. São Paulo: Hucitec; Rio de Janeiro: Abrasco, 1997. Cap. 3. p. 57-95. 
27 CONTI, P.C.R.; SÁBIO, S.A. A utilização do ajuste oclusal na finalização de casos ortodônticos: teorias e conceitos atuais. Rev. Dental Press Ortod. Ortop. Fac., v.4, n.2, p.81-103, mar./abr. 1999.

28 CROSBY, D.R. ; CROSBY, M.S. Professional Liability in Orthodontics. J. Clin. Orthod., v.21, n.3, p.162-166, Mar. 1987.

29 DENARI, Z. Código brasileiro de defesa do consumidor: comentado pelos autores do anteprojeto. 5.ed. Rio de Janeiro: Forense Universitária, 1998. Cap. 4. p.127-197.

30 DIAS, J.A. Da responsabilidade civil. 6.ed. Rio de Janeiro: Forense, 1979. 2 v.

31 DINIZ, M.H. Curso de direito civil brasileiro. 5.ed. São Paulo: Saraiva, 1990. 444p. (Responsabilidade Civil, v.7)

32 FARAH, E.E.; FERRARO, L. Como prevenir problemas com os pacientes - responsabilidade civil: para dentistas, médicos e profissionais da saúde. 3.ed. São Paulo: Quest Editora, 2000. 167p.

33 FÁVERO, F. Medicina legal. 8.ed. São Paulo: Martins, 1966. v.1. 460p. 
34 FERREIRA, W.S. Prescrição e decadência no código de defesa do consumidor. Rev. Dir. Cons., n.10, p.77-96, abr.jun. 1994.

35 FORTES, P.A.C. Ética e saúde: questões éticas, deontológicas e legais, tomada de decisões, autonomia e direitos do paciente, estudo de casos. São Paulo: Editora Pedagógica e Universitária, 1998. p.59-72.

36 FRANÇA, B.H.S. Responsabilidade civil e criminal do cirugião dentista. São Paulo, 1993. 132p. Dissertação (Mestrado em Odontologia Legal e Deontologia) - Faculdade de Odontologia de Piracicaba da Universidade Estadual de Campinas.

37 FRANÇA, G.V. Direito Médico. In: KFOURI NETO, M.A Responsabilidade Civil do Médico. RT, v.654, n.4, p.57-76, abr. 1990.

38 GONÇALVES, M.M. Relação médico/paciente: profilaxia da denúncia contra o profissional. In: CONSELHO REGIONAL DE MEDICINA DO ESTADO DE MINAS GERAIS (CREMEMG). Relação médico/paciente: profilaxia da denúncia contra o profissional. Belo Horizonte: CREMEMG, 1997. p.7-9. 
39 GORMAN, J.C. Efecto de las extracciones de premolares sobre la estabilidad a largo plazo de los incisivos inferiores. In: NANDA, R. BURSTONE, C.J. Contención y estabilidad en ortodoncia. Buenos Aires: Editorial Médica Panamericana, 1994. Cap. 5. p.63-75.

40 HAAS, A.J. Long-term posttreatment evaluation of rapid palatal expansion. Angle Orthod., v.50, n.3, p.189-229, July, 1980.

41 HAWLEY, C.A. A removable retainer. Int. J. Orthod., v.5, n.6, p.291-305, June, 1919.

42 HORN, A. J. A ortodontia hoje na Europa. [Apresentado ao 97º Seminário Internacional de Ortodontia da Sociedade Brasileira de Ortodontia. Rio de Janeiro, 1997].

43 JOONDEPH, D.R.; RIEDEL, R.A. Retention. In: GRABER, T.M.; SWAIN, B.E. Orthodontics - currents principles and techniques. St. Louis: The C.V. Mosby, 1985. p.857-898.

44 JURIS síntese: legislação e jurisprudência. Porto Alegre: Síntese, 1999. 1 CD-Room. Versão 16.

45 KAPLAN, H. The logic of modern retention procedures. Am. J. Orthod. Dentofac. Orthop., v.93, n.4, p.325-340, Apr. 1988. 
46 KFOURI NETO, M. A Responsabilidade Civil do Médico. RT, v.654, n.4, p.57-76, abr. 1990.

47 KFOURI NETO, M. Responsabilidade civil do médico. 2.ed. São Paulo: Revista dos Tribunais, 1996. 580p.

48 LEITE, G. Odontologia legal. Bahia: Nova Era, 1962. 311p.

49 LITTLE, R.M.; WALLEN, T.R.; RIEDEL, R.A. Stability and relapse of mandibular anterior alignment - first premolar extraction cases treated by traditional edgewise orthodontics. Am. J. Orthod., v.80, n.4, p.349-365, Oct. 1981.

50 LITTLE, R.M.; REIDEL, R.A.; ÅRTUN, J. An evaluation changes in mandibular anterior alignment from 10 to 20 years postretention. Am. J. Orthod. Dentofac. Orthop., v.93, n.5, p.423-428, May, 1988.

51 LITTLE, R.M.; RIEDEL, R.A. Postretention evaluation of stability and relapse - Mandibular arches with generalized spacing. Am. J. Orthod. Dentofac. Orthop., v.95, n.1, p.37-41, Jan. 1989.

52 LITTLE, R.M. Estabilidad y recidiva de la alineación del arco dentario. In: NANDA, R.; BURSTONE, C.J. Contención y estabilidad en 
ortodoncia. Buenos Aires: Editorial Médica Panamericana, 1994. Cap. 6. p.77-85.

53 LOUZÃ, R.J. Documentos médicos: aspectos éticos e legais. In SEGRE, M.; COHEN, C. Bioética. São Paulo: EDUSP, 1995. Cap.11. p.159-173.

54 MACHADO, P.A.L. Direito ambiental brasileiro. 8.ed. São Paulo: Malheiros Editores, 2000. p.317-318.

55 MACHEN, D.E. Legal aspects of orthodontic practice. Risk management concepts. Am. J. Orthod. Dentofac. Orthop., v.96, n.5, p.448-449, Nov. 1989.

56 MACHEN, D.E. Legal issues in orthodontics. J. Clin. Orthod., v.25, n.6, p.347-353, June, 1992.

57 MACIEL, C.R. Ainda na cirurgia. In: CONSELHO REGIONAL DE MEDICINA DO ESTADO DE MINAS GERAIS (CREMEMG). Relação médico/paciente: profilaxia da denúncia contra o profissional. Belo Horizonte: CREMEMG, 1997. p.21-25. 
58 MARQUES, C.L. Vinculação própria através da publicidade? A nova visão do código de defesa do consumidor. Rev. Dir. Cons., n.10, p.7-20, abr./jun. 1994.

59 MAYERSON, M.; ARAI, H.Y.; BERKOWITZ, J.; GORMAN, J.C.; HOLT, T.V.; ZAYTOUN, H.S. Management and Marketing. J. Clin. Orthod., v.26, n.9, p.523-538, Sept. 1992.

60 MCNAMARA, J.A.; KRAMER, K.L.; JUENKER, J.P. Invisible retainers. J. Clin. Orthod., v.19, n.8, p.570-578, Aug. 1985.

61 MENEZES, J.D.V. Responsabilidade Profissional. In: SAMICO, A.H.R.; MENEZES, J.D.V.; SILVA, M. Aspectos éticos e legais do exercício da odontologia. 2.ed. Rio de Janeiro: Conselho Federal de Odontologia, 1994. Cap. 8. p.59-65.

62 MOMICCHIOLI, A.; MARTINI, S. La responsabilità professionale in ambito ortognatodontico. Mondo Ortod., v.23, n.2, p.123-132, mar. 1998.

63 MONTEIRO, W.B. Curso de direito civil. 17.ed. São Paulo: Saraiva, 1982. v.5. p.386.

64 MORAES, I.N. Erro médico e a lei. 3.ed. São Paulo: Revista dos Tribunais, 1995. p.314. 
65 MOTTA, C.D. Dano moral por abalo indevido de crédito. RT, v.760, n.2, p.74-94, fev. 1999.

66 MOYERS, R. Ortodontia. 3.ed. Rio de Janeiro: Guanabara Koogan, 1979. Cap. 13. p.375-391.

67 MUCHA, J.N. A estabilidade nas posições dos incisivos inferiores pós-tratamento ortodôntico. Rio de Janeiro, 1987. 301p. Tese (Doutorado em Ortodontia) - Faculdade de Odontologia da Universidade Federal do Rio de Janeiro.

68 NANDA, R.; BURSTONE, C.J. Contención y estabilidad en ortodoncia. Buenos Aires: Editorial Médica Panamericana, 1994. 191p.

69 NANDA, R.S.; NANDA, S.K. Considerations of dentofacial growth in longterm retention and stability: Is active retention needed? Am. J. Orthod. Dentofac. Orthop., v.101, n.4, p.297-302, Apr. 1992.

70 NANDA, R.; ZERNIK, J. Contención y estabilidad, uma revisión. In: NANDA, R.; BURSTONE, C.J. Contención y estabilidad en ortodoncia. Buenos Aires: Editorial Médica Panamericana, 1994. 191p.

71 NASCIMENTO, T.M.C. Responsabilidade civil no código do consumidor. Rio de Janeiro: Aide Editora, 1991. 150p. 
72 NIELSEN, I.L. Consideraciones sobre el crecimiento en la estabilidad del tratamiento ortodóntico. In: NANDA, R.; BURSTONE, C.J. Contención y estabilidad en ortodoncia. Buenos Aires: Editorial Médica Panamericana, 1994. Cap. 1. p.1-22.

73 NOGUEIRA, T.L.T. Direitos básicos do consumidor: a facilitação da defesa dos consumidores e a inversão do ônus da prova. Rev. Dir. Cons., n.10, p.48-60, abr./jun. 1994.

74 OLIVEIRA, M.L.L. Responsabilidade civil odontológica. Belo Horizonte: Del Rey, 1999. 344p.

75 PEREIRA, C.M.S. Responsabilidade civil. 8.ed. Rio de Janeiro: Forense, 1997. p.69.

76 PROFFIT, W.R. Contemporary orthodontics. St. Louis: The C.V. Mosby , 1986. p.455-470.

77 PRUX, O.I. Responsabilidade civil do profissional liberal no código de defesa do consumidor. Belo Horizonte: Del Rey, 1998. 368p.

78 PUEYO, V.M.; GARRIDO, B.R.; SÁNCHEZ, J.A.S. Odontologia legal y forense. Barcelona: Masson, 1994. Cap. 11. p.123-129. 
79 QUEST CONSULTORIA E TREINAMENTO. Responsabilidade civil: guia prático para dentistas, médicos e profissionais da saúde. São Paulo: Quest Editora, 1998. 120p.

80 REITAN, K. Principles of retention and avoidance of post treatment relapse. Am. J. Orthod., v.755, n.6, p.776-790, June, 1969.

81 RIEDEL, R.A. A review of the retention problem. Angle Orthod., v.30, n.4, p.179-199, Oct. 1960.

82 RIEDEL, R.A. Retention In: GRABER, T.M. Current orthodontic concepts and techniques. Philadelphia: W.B. Saunders, 1969. v.2. p.875-918.

83 RIEDEL, R.A. Retention and relapse. J. Clin. Orthod., v.10, n.6, p.454472, June, 1976.

$84 \mathrm{RONCH}$, G.U. Medicina legale in odontostomatologia. Roma: Lombardo, 1993. Cap. 10. p.131-155.

$85 \mathrm{SACHET}$, C.A. Fatores associados ao sucesso do tratamento ortodôntico: uma revisão atualizada dos postulados de Strang. Ponta Grossa, 1999. 83p. Monografía - Escola de Aperfeiçoamento da Associação Brasileira de Odontologia Regional Ponta Grossa. 
86 SADOWSKY, C. Estabilidad a largo plazo luego del tratamiento ortodóntico. In: NANDA, R.; BURSTONE, C.J. Contención y estabilidad en ortodoncia. Buenos Aires: Editorial Médica Panamericana, 1994. Cap. 7. p.87-92.

87 SÉLLOS, V.C. Responsabilidade do profissional liberal pelo fato do serviço no código de proteção e defesa do consumidor. Rev. Dir. Cons., n.10, p.144-161, abr./jun. 1994.

88 SILVA, M.P. Medicina legal. Rio de Janeiro: Itambé, 1972. v.1. p.69.

89 SILVA, M. Documentos Profissionais. In: SAMICO, A.H.R.; MENEZES, J.D.V.; SILVA, M. Aspectos éticos e legais do exercício da odontologia. 2.ed. Rio de Janeiro: Conselho Federal de Odontologia, 1994. Cap. 11. p.76-88.

90 SILVA, M. (Coord.) Compêndio de odontologia legal. Rio de Janeiro: Medsi, 1997. 490p.

91 STOCO, R. Responsabilidade civil e sua interpretação jurisprudencial. 3.ed. São Paulo: Revista dos Tribunais, 1997. Cap. 1. p.49-70. 
92 STRANG, R.W.; THOMPSON, W.M. A text-book of orthodontia. Philadelphia: Lea \& Febiger, 1958. p.763-778.

93 TEIXEIRA FILHO, M.A. Cadernos de processo civil. São Paulo: LTr, 1999. [Prova documental, v.10].

94 THEODORO Jr., H. Aspectos processuais da ação de responsabilidade por erro médico. RT, v.760, n.2, p.40-48, fev. 1999.

95 VARGAS, N.; PETERSON, E. Não me mandem esse lixo! Rev. Veja, a.33, n.38, p.130-132, set. 2000.

96 VARTAN, B. Oclusión \& rehabilitación. 2.ed. Montevideo: R.O. Del Uruguay, 1974. p.185-186.

97 VASCONCELOS, G. Lições de medicina legal. Rio de Janeiro: Forense, 1970. Cap. 10, p.377-394.

98 VÁSQUEZ, A.S. Ética. 11.ed. Rio de Janeiro: Civilização Brasileira, 1989. Cap. 5. p.91-113.

99 WATSON, D.H. Retention and relapse. Int. J. Orthod., v.26, n.3-4, p.49, 1988. 
100 WILLIAMS, R. Eliminating lower retention. J. Clin. Orthod., v.19, n.5, p.342-349, May, 1985. 


\section{SUMMARY}

\section{THE DENTIST SURGEON'S CIVIL RESPONSABILITY: THE ORTHODONTIC POST-TREATMENT}

The aim of this work was to investigate the clinical procedures and the orthodontist's difficulties in the orthodontic post-treatment (retention and postretention), analyzing if the adopted procedures are able to satisfy finished the correction treatment, according to the determinations of the Civil Code and the Costumer's Defense Code, and the relationship between the patient and the professional. The orthodontic biography is controverted about the technics, duration, stability and the difficulties of the treatment. A questionnaire was sent by postal service to all of the specialists inscribed in the CRO/PR; 95 of them have answered. The percentual annalyses of the answers sent had shown that $73,6 \%$ of the professionals don't have plain conscience about the term to complain in Justice, with regard to the dentistry treatment. They aren't aware of the article number 177 from the Brazilian Civil Code (83,1\%). Among them, adopt the contract $(67 \%)$, make special clauses (48\%), but are not conscient with regard to their legality (59\%). The greater number $(60 \%)$ considerate the Orthodontist's Civil Responsibility as a result. In the case of reincident postretention, $70 \%$ of them propose the 
orthodontic re-treatment. After the patient's insatisfaction about the result of the orthodontic treatment, $55 \%$ of the professionals have answered that the would look for, anyway, to evitate them to propose civil lawsuit. The dissembled of the law and the orthodontic post-treatment controversies, can take the orthodontist to the Civil Court, to reply about the dental movements and neuromuscular alteration that occurred in this phase. 


\section{APÊNDICES}




\title{
APÊNDICE 1
}

\author{
UNIVERSIDADE DE SAO PAULO \\ FACULDADE DE ODONTOLOGIA
}

PARECER $n^{\circ} 73 / 99$

Com base em parecer de relator, foi APROVADO nesta data, pelo Comitê de Ética em Pesquisa (CEP). o protocolo de pesquisa "O Pós-Tratamento Ortodôntico", de responsabilidade do pesquisador Fernando Fernandes, sob orientaçāo da Professora Doutora Hilda Ferreira Cardozo.

Săo Paulo, 26 de agosto de 1999

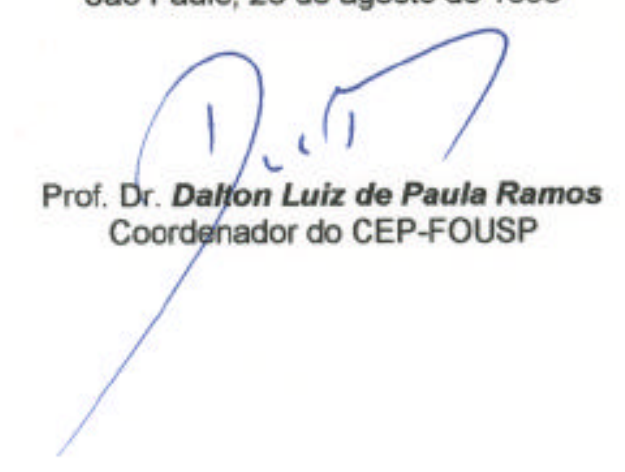

Av. Prof. Lineu Prestes, 2227 - Cidade Universitária "Armando de Salles Oliveira" CEP 05508-900 São Paulo - SP FAX (011) 814.9281 - TELEX (011) 36950 - Tels: PABX (011) 813.6944 Diretoria (011) 814.0062 - Contabilidade/Compras (011) 814.9281

Impresso nos. S. 


\section{APÊNDICE 2a}

\section{QUESTIONÁRIO}

Por gentileza, solicitamos o preenchimento e o envio do questionário abaixo exposto. O mesmo será instrumento da elaboração de pesquisa, envolvendo as áreas de Deontologia e Odontologia Legal com a Ortodontia.

Nome:

Sexo: ( ) masculino ( ) feminino

Idade: anos.

Formado pela Faculdade de Odontologia:

Data da conclusão do Curso de Graduação: / /19 .

Data da conclusão do Curso de Pós-Graduação: / /19

Pós-Graduado em Odontologia, área de Ortodontia: (entidade)

Em nível de Especialização:

Em nível de Mestrado:

Em nível de Doutorado:

1. Solicita documentação inicial?

\section{I - DA DOCUMENTAÇÃO PROFISSIONAL}
( ) Sim
( ) não

2. Solicita documentação ao término de tratamento ortododôntico?

( ) $\operatorname{Sim} \quad$ ( ) Não

3. Tem como conduta a rotina de arquivar a documentação?
( ) Sim
( ) Não

4. Por quantos anos?
( ) 1 ano
( ) 5 anos
( ) 15 anos
( ) 20 anos
( ) 10 anos
( ) mais de 20 anos

\section{II - DA RESPONSABILIDADE PROFISSIONAL}

1. Tem consciência plena da limitação do tempo para reclames à Justiça em relação ao tratamento odontológico?
( ) $\operatorname{Sim}$
( ) Não

2. Conhece o Artigo 177 do Código Civil?
( ) Sim
( ) Não

3. Conhece o termo sublinhado?

As provas que porventura o Cirurgião Dentista apresente à Justiça são pré-constituídas.
( ) $\operatorname{Sim}$
( ) Não

4. Adota algum modelo ou forma de contrato pertinente ao tratamento que está em vias de ser instituído num paciente?
( ) $\operatorname{Sim}$
( ) Não

5. Faz ressalvas no corpo do mesmo?

( ) Sim ( ) Não

6. Tem ciência da validade das mesmas?

( ) $\operatorname{Sim}$ ( ) Não

7. Como considera a Responsabilidade Civil do Cirurgião Dentista, especificamente quanto ao tratamento ortodôntico?
( ) Responsabilidade de meio
( ) Responsabilidade de resultado

8. Quando o paciente solicita a retirada de documentos da sua clínica, qual/quais procedimento(s) é/são adotado(s)?
( ) Não entregar
( ) Entregar
( ) Entregar e solicitar a assinatura do termo de retirada 


\section{APÊNDICE 2b}

\section{III - DO PÓS-TRATAMENTO ORTODÔNTICO}

1. Adota como rotina aparelhos de contenção?

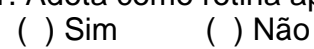

2. Qual o período de uso recomendado?

( ) Diurno ( ) Noturno ( ) Integral

3. Por quanto tempo?
( ) 6 meses ( ) 1 ano
( ) 2 anos
( ) 1 ano e meio
( ) 3 anos
( ) 2 anos e meio
( ) mais tempo (especificar):

4. Mantém o Retentor inferior colado por quanto tempo?
( ) 6 meses
( ) 1 ano
( ) 1 ano e meio
( ) 2 anos
( ) 2 anos e meio
( ) 3 anos
( ) até 5 anos
( ) mais tempo (especificar):

5. Nos casos de recidiva, durante o período de contenção, qual/quais conduta(s) é/são adotada(s)?

( ) Retratamento Ortodôntico

( ) Ajuste oclusal

( ) Reconstruções estéticas com auxílio da Dentística

( ) Reconstruções estéticas com auxílio da Prótese

( ) Reconstruções oclusais com auxílio da Dentística

( ) Reconstruções oclusais com auxílio da Prótese

( ) Cirurgia

( ) Nenhum procedimento é adotado

6. No período pós-contenção, supervisiona seu paciente com que freqüência?
( ) Ano em ano
( ) Dois em dois anos
( ) Três em três anos
( ) Cinco em cinco anos
( ) Dez em dez anos
( ) Não supervisiona

7. Nos casos de recidiva, após o período de contenção, qual conduta adotaria?

( ) Informar ao paciente que é uma circunstância "natural"

( ) Informar ao paciente que é uma circunstância "natural" e que nenhum procedimento clínico será adotado

( ) Informar ao paciente que é uma circunstância "natural" e propõe o retratamento ortodôntico

( ) Informar ao paciente que, devido a circunstâncias atípicas, ensejaram o retratamento ortodôntico e cobrar novos honorários profissionais.

( ) Nada informar ao paciente e não retratar o caso clínico

( ) Nada informar ao paciente e retratar o caso clínico

( ) Informar somente que será necessário retratar o caso clínico e cobrar novos honorários profissionais

8. Perante o paciente insatisfeito com os resultados do tratamento ortodôntico, qual conduta adotaria?

( ) Solicitaria que o mesmo procurasse outro profissional

( ) Desconsideraria os reclames do paciente

( ) Perante os reclames do paciente Ihe retribuiria com a seguinte colocação: Procure seus direitos!

( ) Procuraria, de qualquer forma, evitar que o paciente agilizasse ações de ordem cível

( ) Comunicaria o fato ao seu advogado e o contrataria, mesmo que ainda numa condição pré-litigiosa

( ) Outra (especifique).

9. Profissionamente já esteve envolvido numa ação de Responsabilidade Civil impetrada por paciente?
( ) $\operatorname{Sim}$
( ) Não 


\title{
APÊNDICE 3
}

\author{
UNIVERSIDADE DE SAOPAULO \\ FACULDADE DE ODONTOLOGIA
}

Prezado(a) Colega

Tomamos a liberdade de utilizar um pouco do seu tempo e atençälo.

Preocupados com a nossa especialidade, e agora cursando o Mestrado em Deontologia e Odontologia Legal na Faculdade de Odontologia da Universidade de São Paulo, apresentamos o Projeto de Pesquisa "Responsabilidade Civil do Cirurgiăe Dentista: O Pós-Tratamento Ortodôntico", aprovado pelo Comitê de Ética em Pesquisa da FOUSP mediante o parecer 73/99.

Com o intuito de conhecermos as atuais condutas adotadas pelo(a) especialista após a conclustáo do tratamento ortodôntico, elaboramos diversas questôes que abordam a temática acima. Salientamos que todos(as) os(as) cirurgiōes(ãs)-dentistas devidamente inscritos(as) no CRO/Paraná, com seus registros no CFO como especialistas cm Ortodontia, estarilo recebendo este questionário. Destarte, o mesmo segue em anexo.

Solicitamos gentilmente que, após o seu preenchimento, remeta-o com a maior brevidade possivel. Para tal designio, segue um envelope pré-endereçado e já selado. Esclarecemos, outrossim, que não será necessária a identificaçăo do(a) entrevistado(a) quando do preenchimento e envio do questionário.

Pretendemos, após a tabulação computadorizada dos dados e redaçĩo final do trabalho cientifico (dissertaçĭo de mestrado), publicar os resultados em forma de um protocolo para consulta e orientactio. abordando condutas efou medidas que poderẳo ser adotadas no tocante à Responsabilidade Civil do Cinurgiło Dentista e o Pós-Tratamento Ortodôntico.

Atenciosamente.

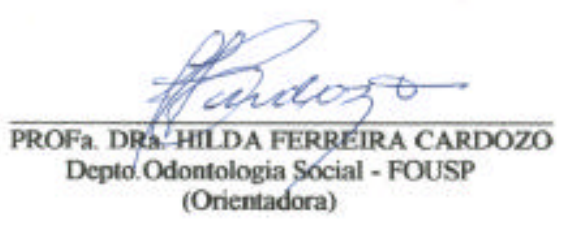

(Orientadora)

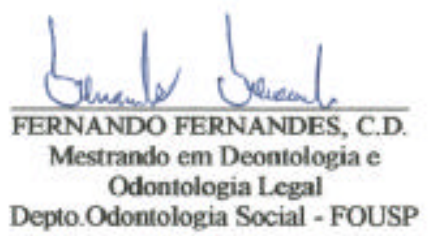

Depto.Odontologia Social - FOUSP

Av. Prof Lineu Prestes, 2227 - Cidade Universitária "Armando de Salles Oliveira" CEP 05508-900 Sào Paulo - SP FAX (011) 814.9281 - TELEX (011) 36950 - Tels: PABX (011) 813.6944 Diretoria (011) 814.0062 - Contabilidade/Compras (011) 814.9281 